\title{
Bronze Age Copper Produced at Mitterberg, Austria, and its Distribution
}

\author{
Ernst Pernicka \\ Joachim Lutz \\ Thomas Stöllner
}

\begin{abstract}
The rich copper ore deposits in the eastern Alps have long been considered as important sources for copper in prehistoric central Europe. However, the role that each deposit played is not clear. To evaluate the amount of prehistoric copper produced from the various mining regions, we attempted to link prehistoric metal artefacts with copper ores based on the geochemical characteristics of the ore deposits that were exploited in ancient times. Alongside the usage of ores as shown by the finished products, the production aspects, the quantity and variation over time must also be considered. Recent archaeological investigation has allowed these datasets to be combined in order to show the importance of one of the largest Bronze Age mining fields in Europe. More than 120 ore samples from the well-known mining regions of Mitterberg, Viehhofen, and Kitzbühel were analysed for lead isotope ratios and trace element concentrations. These results were combined with analytical data generated by previous archaeometallurgical projects in order to compile a substantial database for comparative studies. In the Early Bronze Age, most metal artefacts were made of copper or bronze with fahlore impurity patterns, and most examples from this period match the fahlore deposits in Schwaz and Brixlegg. At the end of the Early Bronze Age, a new variety of copper with low concentrations of impurities appeared. The impurity patterns of these examples match the ores from the Mitterberg region. Later, in the Middle Bronze Age, this variety of copper almost completely replaced the fahlore copper. In the Late Bronze Age, the exploitation of the ores changed again and copper with a fahlore signature reappeared. The reason for the renewed copper production from fahlores might have been a decline of the chalcopyrite mines. But it was more likely due to the fact that the rising demand for copper could no longer be met by the chalcopyrite mines alone. The examples from the Early Iron Age show no fundamental changes in metal composition. The copper metallurgy in the Early Iron Age is based on the traditions of the Late Bronze Age.
\end{abstract}

\section{Keywords}

Mitterberg, prehistoric mining, copper production, lead isotope analysis, provenance of copper, eastern Alps.
Zusammenfassung - Bronzezeitliche Produktion von Kupfer am Mitterberg und seine Verteilung

Die reichen Kupferlagerstätten in den Ostalpen werden seit langem als wichtige Rohstoffquellen für das Kupfer im prähistorischen Europa betrachtet. Dennoch war bislang nicht so klar, welche Rolle einzelnen Lagerstätten in diesem Zusammenhang zukam. Um die Bedeutung der Kupferproduktion in einzelnen Bergbaurevieren besser zu verstehen zu können, wurde nach der Verbindung zwischen Metallartefakten und der geochemischen Charakteristik einzelner in prähistorischer Zeit abgebauten Lagerstätten gesucht. Doch neben den Aspekten der Nutzung von Erzkörpern, welche durch die Endprodukte angesprochen sind, müssen auch Produktionsfragen, etwa nach der Gesamtmenge der Kupferproduktion und ihrer zeitlichen Variation, beachtet werden. Jüngste archäologische Untersuchungen erlauben eine präzise Kombination beider Datengrundlagen. Sie ermöglichen neue Einblicke in die Bedeutung einer der größten Bergbaulandschaften der Bronzezeit in Europa, des Mitterbergs. Mehr als 120 Erzproben der gut bekannten Bergbaureviere Mitterberg, Kitzbühel und Viehhofen wurden anhand ihrer Pb-Isotopen-Verhältnisse und Spurenelementmuster untersucht. Diese Ergebnisse wurden mit bisherigen analytischen Daten archäometallurgischer Projekte kombiniert und so eine substantielle Basis für Vergleichsstudien erreicht.

In der Frühbronzezeit bestanden die meisten Metallobjekte aus einem Kupfer mit typischer Fahlerzsignatur. Es passt gut zu den Fahlerzlagerstätten von Schwaz und Brixlegg. Am Ende der Frühbronzezeit erschien eine neue Kupfervarietät mit geringeren Spurenund Nebenelementanteilen. Dieses Spurenelementmuster stimmt bestens mit den Erzen der Mitterberger Bergbauregion überein. In späterer Zeit verdrängte diese Kupfersorte gänzlich das FahlerzKupfer. In der späten Bronzezeit änderte sich die Ausbeute der Erze erneut und Fahlerzkupfer-Signaturen erschienen erneut. Der Grund für die erneute Ausbeute des Fahlerzkupfers könnte ein Rückgehen der Kupferkiesproduktion sein, wahrscheinlicher ist aber, dass die Kupferkiesproduktion den Bedarf an Kupfer allein nicht mehr zu decken vermochte. Die Funde der frühen Eisenzeit zeigen keine fundamentalen Änderungen in der Metallzusammensetzung mehr. Die Kupferproduktion der frühen Eisenzeit basiert im Wesentlichen auf den Traditionen der Spätbronzezeit. 


\section{Schlüsselbegriffe}

Mitterberg, prähistorischer Bergbau, Kupferproduktion, Bleiisotopenanalyse, Herkunft von Kupfer, Ostalpen.

\section{Introduction (E. Pernicka, J. Lutz, T. Stöllner)}

It has long been known that the copper deposits in the Mitterberg region in the eastern Alps were mined on a large scale. Mitterberg is actually the first copper mining site that was investigated archaeologically. ${ }^{1}$ Ground-breaking studies on the production processes used were published by Kyrle and Klose, ${ }^{2}$ and on the mining techniques and ore beneficiation by Zschocke and Preuschen. ${ }^{3}$ They documented numerous mines and the remains of extractive metallurgy like furnaces and close to 200 slag sites. The site was exceptionally favourable for the study of ancient mining and smelting techniques, because the mine seems to have been abandoned after the Bronze Age. It was only rediscovered in 1827; mining resumed in 1837 and ended in 1977. There was therefore no medieval or later exploitation of the mine that would have destroyed most of the ancient traces.

Further investigation addressed earlier research activities in the area around the mines, e.g. the work of Richard Pittioni and his fellow researchers ${ }^{4}$ at the prehistoric mining region of Kitzbühel some $50 \mathrm{~km}$ further west. In the Mitterberg region, archaeological research concentrated on ore beneficiation ${ }^{5}$ and the search for settlement structures. These are preferentially located in the valleys and the focus was on subsistence strategies ${ }^{6}$ and the spatial organisations of the mining communities and their structures. ${ }^{7}$ New underground investigations ${ }^{8}$ began with the HiMAT research cluster that was based at the University of Innsbruck and comprised multidisciplinary research on all aspects of mining in the eastern Alps. ${ }^{9}$ A summary of this project was published in the series 'Archäologie Österreichs Spezial' Volume $4 .{ }^{10}$ In the following paper, we will concentrate mainly on the mining region around the town of Bischofshofen, commonly addressed simply as the Mitterberg prehistoric mining region, its production of copper in the Bronze Age as reflected by field studies and chemical and isotope analy-

\footnotetext{
1 Much 1878. - Much 1879.

2 Klose 1918. - Kyrle 1918.

3 Zschocke, Preuschen 1932.

4 Preuschen, Pittioni 1937. - Pittioni 1947. - Preuschen, PitTIONI 1954.

5 Eibner-Persy, Eibner 1970. - Eibner 1972. - Eibner 1973.

6 Lippert 1992. - ShenNAN 1995.

7 StÖllner 2003.

8 Stöllner, Eibner, Cierny 2004. - Stöllner et al. 2009.

9 Oeggl et al. 2008.

10 Goldenberg et al. 2012. - STÖLLnER et al. 2012.
}

ses of its ores, and by copper-based artefacts in central and northern Europe.

\section{Geological Setting and Mineralisations (E. Pernicka)}

The most important ore deposits in North Tyrol, Salzburg and Styria occur in the Greywacke Zone, a belt of Paleozoic sedimentary rocks trending from east to west in the Austrian Alps between the northern Calcareous Alps and the central eastern Alps. The unit consists of Paleozoic sediments (turbidites, greywackes and limestones) from the Ordovician to Devonian age and of mafic volcanic rocks from the Cambrian/Ordovician age. These rocks are relatively soft and prone to weathering. In the western Upper Inn Valley near the Arlberg, the Greywacke Zone forms only a narrow strip, but then widens to the east to include large parts of the Tux Alps, the Kitzbühel Alps and the Salzburg Slate Mountains. Further to the east it runs along the upper Enns Valley, the Eisenerz Alps and the Mürz Valley. Numerous copper deposits occur in this sedimentary unit, related to mafic volcanism. The primary ore assemblage consists mainly of chalcopyrite and pyrite ${ }^{11}$ on the one hand, and fahlore ${ }^{12}$ on the other. Traces of ancient mining show that many of these deposits were exploited in prehistory.

Well-known prehistoric mining areas belonging to this zone are (from west to east) Schwaz and Brixlegg in the Lower Inn Valley, ${ }^{13}$ the Kitzbühel region, ${ }^{14}$ Viehhofen in the Glemmtal, the Mitterberg region south of Salzburg ${ }^{15}$ and other mining districts in the Eisenerz Alps and Lower Austria further to the east (Fig. 1).

It has always been presumed that these mines supplied copper for large parts of central Europe in the Bronze Age. However, such claims have not been supported convincingly by demonstrating a clear relationship between ores and Bronze Age metal artefacts, although many analyses were performed by Pittioni and Neuninger. ${ }^{16}$ An example is the discussion on the provenance of the so-called Ösenringe, which are mainly found in hoards, and in some cases in large numbers. They were usually interpreted as ingots, i. e. for the storage and transport of raw copper, and their geographical distribution was related to the east Alpine copper deposits. ${ }^{17}$

11 Mitterberg: Bernhard 1965. - Weber, Pausweg, Medwenitsch 1972. - Weber, Pausweg , Medwenitsch 1973. - Weber 1997.

12 Schwaz/Brixlegg: Gstrein 1988. - Gstrein 1989.

13 Rieser, Schrattenthaler 1998-1999.

14 Preuschen, Pittioni 1937. - Goldenberg 2004. - KochWaldner, Klaunzer 2015.

15 Zschocke, Preuschen 1932. - Eibner 1994. - Stöllner 2011. 16 E.g. Pittioni 1957. - Pittioni 1959. - Neuninger, Pittioni 1962. - Neuninger, Pittioni 1963.

17 Bath-Bílková 1973. - Menke 1982. 


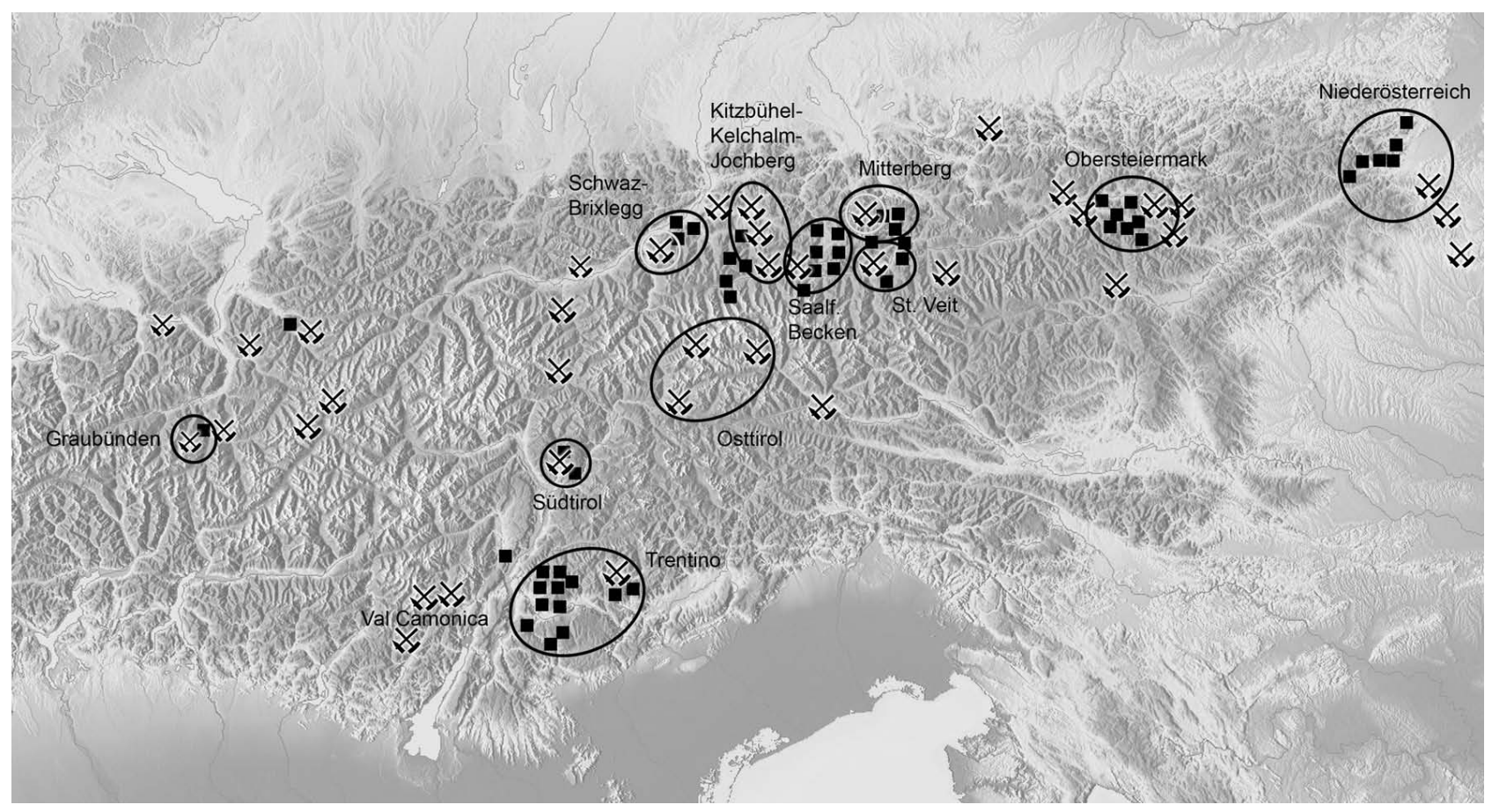

Fig. 1. Prehistoric mining districts in the eastern Alps. Graphic symbols: squares = areas with a large number of copper smelting sites; downward pick hammer $=$ ancient/prehistoric mining areas; circles $=$ prehistoric copper-producing mining regions (after STÖLLNER 2009).

On the other hand, work by Neuninger and Pittioni $\mathrm{i}^{18}$ based on trace element analyses concluded that the Ösenhalsringe came from Slovakia or the Carpathian Mountains because of the high concentrations of arsenic, antimony and silver in these artefacts, suggesting the use of fahlores for the production of this copper. Since fahlores are only an accessory component in the ores from the Mitterberg, they excluded this region as a possible source for this type of copper. However, a small percentage of the Ösenringe did match the Mitterberg ores chemically and they called this type of copper, with a significant trace-element pattern, 'Typ Mitterberg-Kelchalm'. ${ }^{19}$ The problem with these analyses is that they were obtained using semiquantitative atomic emission spectroscopy. Element concentrations were only reported with symbols $(+++,++,+, \operatorname{tr})$ and the authors stated that each symbol would indicate the order of magnitude of the element concentrations. Unfortunately, this is not correct as has been shown by Christoforidis and colleagues, ${ }^{20}$ who compared the results with neutron activation analyses of a number of the same ore samples from Kitzbühel and Schwaz that were analysed by Neuninger. Subsequently, most geochemical and mineralogical investigations focused on the mining areas of Schwaz and Brixlegg due to their historical

18 Neuninger, Pittioni 1963.

19 Neuninger, Pittioni 1963.

20 Christoforidis, Pernicka, Schickler 1988. importance for metal production in more recent times beginning in the $15^{\text {th }}$ century AD. ${ }^{21}$ In contrast to these areas in North Tyrol, only limited modern analytical data (INAA, ICP-MS, lead isotopes) were available from the Mitterberg region. These will be presented here.

In the Mitterberg region there are three recognisable lithological units ${ }^{22}$ that are interpreted as sediments ranging from the Silurian to the Devonian age (grey series) and interspersed with basal conglomerates (e.g. at the Götschenberg), to Upper Carbonaceous (violet series) and Permian (green series). The grey series was deposited in a marine basin, partly under strongly reducing conditions. This is reflected in the vegetation remains that are rich in uranium. The series was folded during the Variscan orogeny and is discordantly overlain by the violet series that resembles the formation of flysch. It is also characterised by uranium anomalies. The green series was deposited under very different conditions that may have mobilised the copper, but essentially, the copper deposits are mainly strata-bound. The Alpine orogeny caused fractures in the green series and may have led to partial remobilisation of the metal inventory according to some features of a hydrothermal deposition like bleaching

21 HÖPPNER et al. 2005.

22 Weber, Pausweg, Medwenitsch 1972. - Weber, Pausweg, Medwenitsch 1973. 


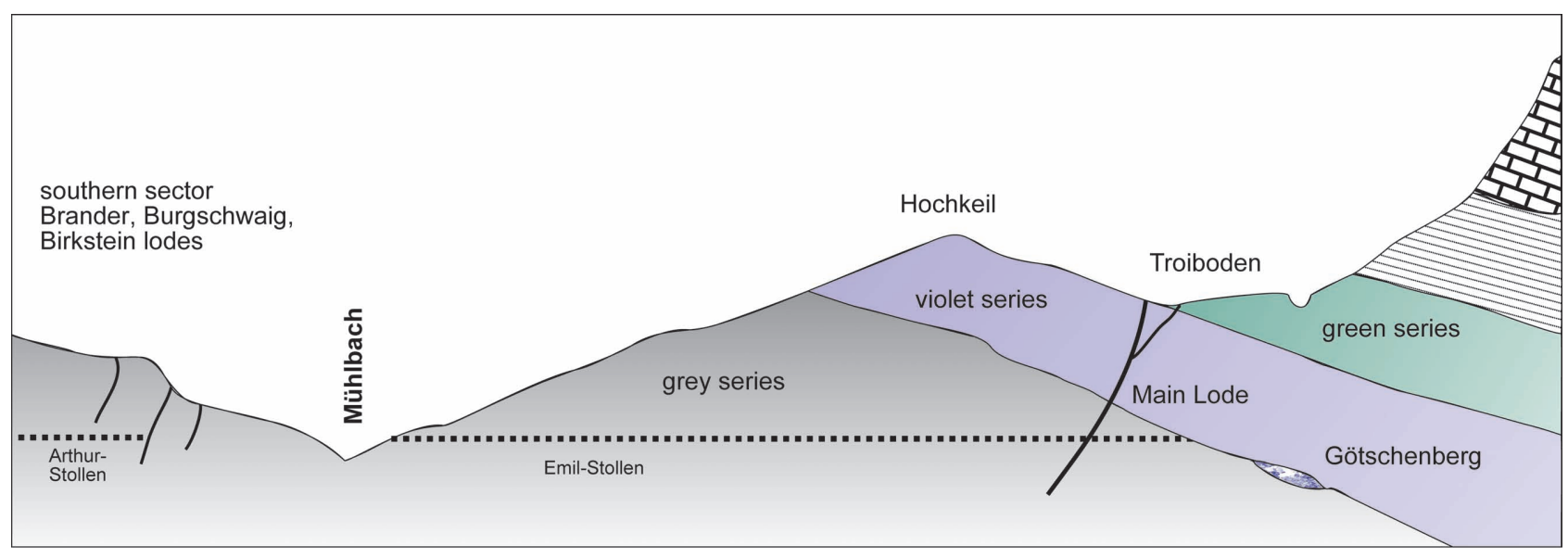

Fig. 2. Simplified geological profile of the Mitterberg region (Weber, Pausweg, Medwenitsch 1972) with the southern sector and the main lode, and an intercalation of quartzitic conglomerates in the lower parts of the violet series that are exposed at the Götschenberg at a lower altitude (Deutsches Bergbau-Museum, Bochum, Ruhr-Universität Bochum, Institute of Archaeological Studies).

zones along the main lode reported by Clasen. ${ }^{23} \mathrm{~A}$ schematic profile of these geological units and their relationship to the copper deposits is shown in Fig. 2.

As described above, the mines of the region can be divided into three sectors: the main lode that continues towards the east with several smaller veins; the sector south of the Mühlbach creek with the Brander, Burgschwaig, and Birkstein lodes; and finally the Buchberg and Winkel lodes east of the Salzach River. The mineralisations also show three types that are usually associated with different stages of ore formation. The main lode north of the river is a very large discordant steep vein system that cuts the grey and the violet series and is zoned vertically. According to Bernhard, ${ }^{24}$ the first mineralisation stage was dominated by nickel-rich pyrite $\left(\mathrm{FeS}_{2}\right)$, the second by chalcopyrite $\left(\mathrm{CuFeS}_{2}\right)$, which is the dominant mineral species, and the third by cobalt-rich copper ores mainly in the eastern extensions from the main lode and in the Buchberg lode that also strikes on an axis from north to south. In the southern sector the mineralisation is strictly strata-bound with small veinlets of pyrite, chalcopyrite and erythrite (an oxidised cobalt arsenate). Accessory minerals include gersdorffite (NiAsS), millerite (NiS), arsenopyrite (FeAsS) and fahlore, mainly of the tetrahedrite $\left(\mathrm{Cu}_{12} \mathrm{Sb}_{4} \mathrm{~S}_{13}\right)$ type. This can include arsenic, because tetrahedrite forms a solid solution with its arsenic-bearing tennantite $\left(\mathrm{Cu}_{12} \mathrm{As}_{4} \mathrm{~S}_{13}\right)$. A host of other rather minor accessory minerals are known but are irrelevant for this discussion. The gangue material mainly consists of quartz ( $\mathrm{SiO} 2)$, dolomite $\left(\mathrm{CaMg}\left(\mathrm{CO}_{3}\right)_{2}\right)$, siderite $\left(\mathrm{FeCO}_{3}\right)$ and ankerite $\left(\mathrm{Ca}(\mathrm{Fe}, \mathrm{Mg}, \mathrm{Mn})\left(\mathrm{CO}_{3}\right)_{2}\right)$.

23 Clasen 1974.

24 BernHARd 1965.

\section{The Mitterberg: A Large Copper-Producing Region in the $2^{\text {nd }}$ Millennium BC (T. Stöllner)}

If we consider the question of a metal ore deposit and its socioeconomic importance, we must look both at processes of production and consumption. Ideally these factors overlap chronologically and/or in quantity once produced and consumed. However, since the record of archaeological and archaeometric sources is incomplete, we must be more moderate in our expectations.

Our knowledge about copper production in the eastern and southern Alps has reached a considerable level:25 technology, subsistence and development in time can be described in general terms. In some parts of the mining district, our knowledge includes detailed insights into the structural components of living and working and their development over time. This is certainly the case for the mining sectors alongside the Salzach Valley and around the town of Bischofshofen ${ }^{26}$ (Fig. 3).

The area is generally known as the Mitterberg mining region although the Mitterberg is only the name of an Alpine pastoral landscape around the largest mining relics of the Bronze Age (see above). Over the course of the research that started here very early in the $19^{\text {th }}$ century, this region has gained a high profile. Consequently, the Mitterberg process describes the technological and economic complex and the principles of copper production from chalcopyrite, which is the major ore mineral in this region. ${ }^{27}$ This technological complex consists of deep underground mining, various ore beneficiation steps and smelting in shaft furnaces, whose

25 See various contributions in StöLlner, OegGL 2015.

26 EIbNer 1994. - Recently StöLlner 2015.

27 EibNer 1982. 


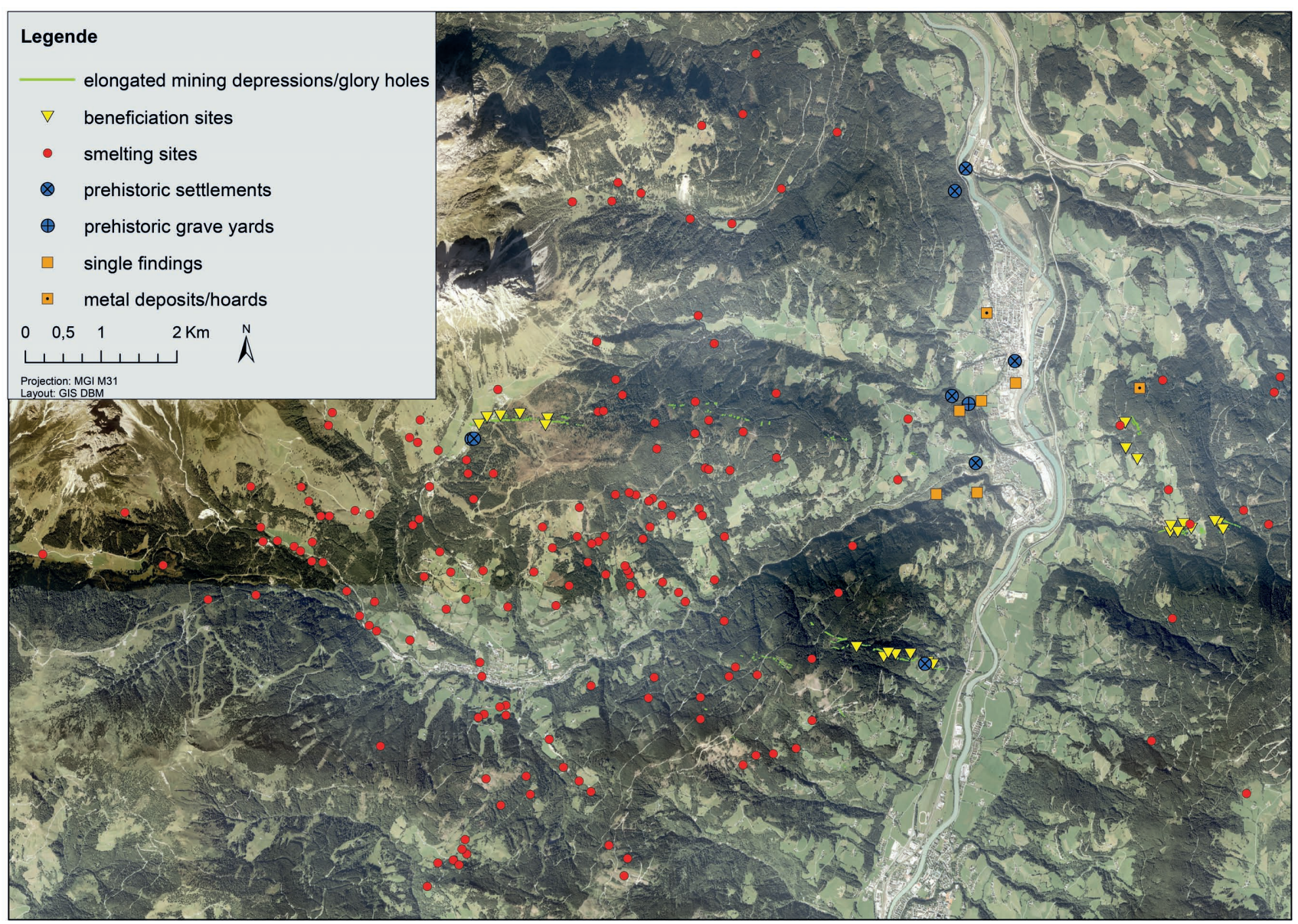

Fig. 3. The Mitterberg mining region (the mining field of Mühlbach-Bischofshofen) at the centre of the Salzach-Pongau region as displayed by mining lodes (and their surface depressions), beneficiation and smelting sites as well as settlements, single finds and graves (Deutsches Bergbau-Museum, Bochum, Ruhr-Universität Bochum, Institute of Archaeological Studies).

construction and operation principles are characteristic of many of the east Alpine mining regions of the Bronze- and Early Iron Ages. However, it is nowadays clear that the earliest remains of this technology are found in the Salzach-Pongau area, from where it may have spread to the entire eastern and southern Alps and beyond.28

\section{The Mitterberg Process: Regional and Chronological} Aspects (T. Stöllner)

According to calculations by Zschocke and Preuschen ${ }^{29}$ and more recently by Stöllner et al., ${ }^{30}$ we can consider the Salzach-Pongau mining region as the largest and most productive (see below) known in the eastern Alps and possibly even in Europe in the middle of the $2^{\text {nd }}$ millennium BC. But to understand the socioeconomic conditions, the effects of population, landscape and exchange patterns (such as trade),

28 STÖLLNER 2009.

29 Zschocke, Preuschen 1932.

30 Stöllner, Hanning, Hornschuch 2011. it may be worth regarding the chronology of the spatial distribution in the Salzach-Pongau mining region. There is a bundle of ore deposits that were exploited during the $2^{\text {nd }}$ and the early $1^{\text {st }}$ millennium BC. The so-called 'main lode' in the north of the region must be considered the most important of the mining sectors. The veins range over several kilometres in a direction stretching from east to west from the piedmont of the Hochkönig massif and north of the Hochkeil peak to the eastern lodes near Bischofshofen. ${ }^{31}$ The western part, known as the St Josefi lode and its accompanying side lodes were mined to depths of nearly $120 \mathrm{~m}$ below the surface. Around the mines, several large ore dressing areas are known that reflect the time-consuming work of dry and wet ore beneficiation. At a somewhat greater distance, nearly 100 smelting sites were documented and partly dated (Fig. 3), which provide perfect insight into the spatial organisation of wood consumption, transport of (beneficiated) ores to the smelting sites, and the matte production that

31 Bernhard 1965. - Weber, Pausweg, Medwenitsch 1973. 


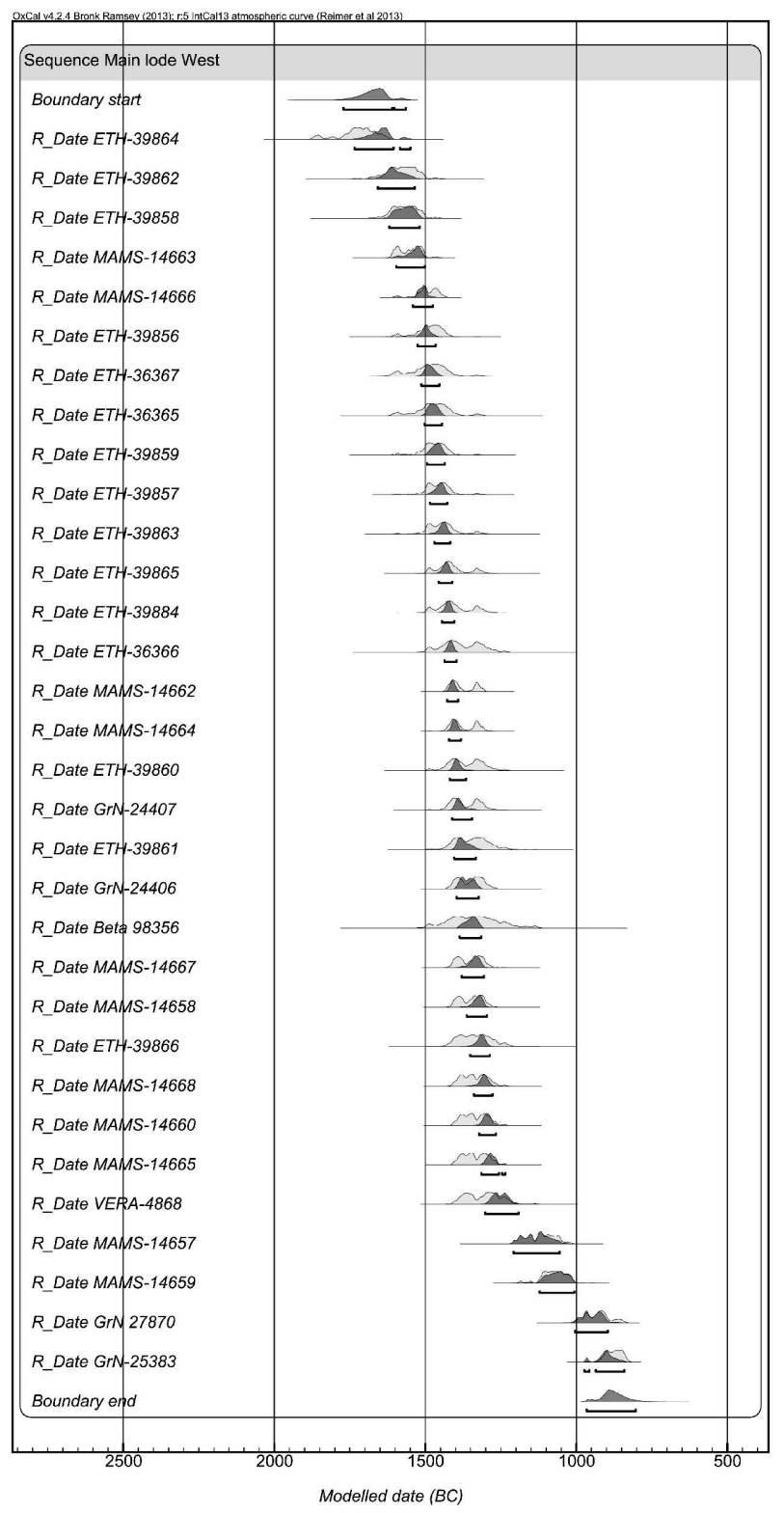

Fig. 4. Bayesian modelling of the AMS ${ }^{14} \mathrm{C}$ dates from the main lode (after STÖLLnER 2009; remodelled with OxCal v4.2.4) (Deutsches Bergbau-Museum, Bochum, Ruhr-Universität Bochum, Institute of Archaeological Studies).

took place there. It is not yet clear whether black copper was also produced at these sites that were operated presumably in a seasonal manner. Production seems to begin around the $18^{\text {th }} / 17^{\text {th }}$ century BC and reaches a climax between the $15^{\text {th }}$ and the $13^{\text {th }}$ centuries. A few younger radiocarbon dates as well as pollen and heavy metal records from local bogs indicate a general decrease in activity (Fig. 4). ${ }^{32}$

The mining sectors alongside the Salzach Valley are geologically different. The southern sector for instance consists of three lodes that are embedded syngenetically in the Si-

32 Breitenlechner et al. 2014. lurian and Devonian slates of the grey series. ${ }^{33}$ These ore lodes do not match the rich ore mineralisation of the main lode. The Brander, Burgschweig and the Birkstein lodes are aligned alongside the Einödberg ridge from the northwest to southeast (Fig. 3). Evidence for ancient mining, such as mining depressions and glory holes, is abundant on the surface, accompanied by underground exposures as in the Arthur-Stollen. In the Middle Bronze Age, mining galleries reached depths of nearly $200 \mathrm{~m} .{ }^{34}$ Similar to the main lode, beneficiation areas and also some smelting sites are located besides the mining entrances along the steep slopes of the Einöd ridge. From our field work it seems that all the mining and smelting activities were smaller in size and number compared with the main lode. Most of our knowledge derives from archaeological investigations at the Brander lode. Mining started there no later than the $19^{\text {th }}$ and $18^{\text {th }}$ century BC, and lasted at least until the Urnfield and Early Hallstatt periods. This is not yet reflected by ${ }^{14} \mathrm{C}$ or dendrodates (Fig. 5) but by some single finds from the mining house ensemble at the Einödberg near the Höch farmstead. ${ }^{35}$ Even small-scale Copper Age mining seems conceivable according to scattered pottery fragments discovered around the Höch farmstead. ${ }^{36}$

A third mining area can be located east of the Salzach Valley. The Buchberg lode represents a series of mining depressions running from north to south with at least two lines of glory holes (Fig. 3). It seems that two lodes near the surface were mined during the Bronze Age. Only a few smelting sites are known in the surrounding area. According to modern underground galleries, the prehistoric miners did not reach the $100 \mathrm{~m}$ level below surface, but stopped before that. South of the Buchberg lode the east-west trending Winkel or Arzberg lode is situated. Only little is known about the time of exploitation and the technology used to mine this site, but at least one of the neighboring smelting sites was recently surveyed and dated to the Middle to Late Bronze Age. ${ }^{37}$ The variety of stone tools found in the surroundings of the Winkel lode suggests domestic activities nearby. This fits the general impression gained from all the mining sectors of the Mitterberg region. Mining houses and camps seem to reflect the usual way of life in the production areas during the (presumably) seasonally organised working periods. Although the exploitation of the Buchberg and Winkel lodes has not been precisely dated yet, there is no doubt it generally belongs to the Bronze Age. Another indication is provided by the Sky Disc of Nebra whose metal

33 Weber, Pausweg, Medwenitsch 1972.

34 STÖllner et al. 2009.

35 Zschocke, Preuschen 1932, 114-125. - Recently Eibner 2016.

36 StÖllner 2009, 42-45 and Fig. 5.

37 Stöllner 2009, 44 and Fig. 6. 


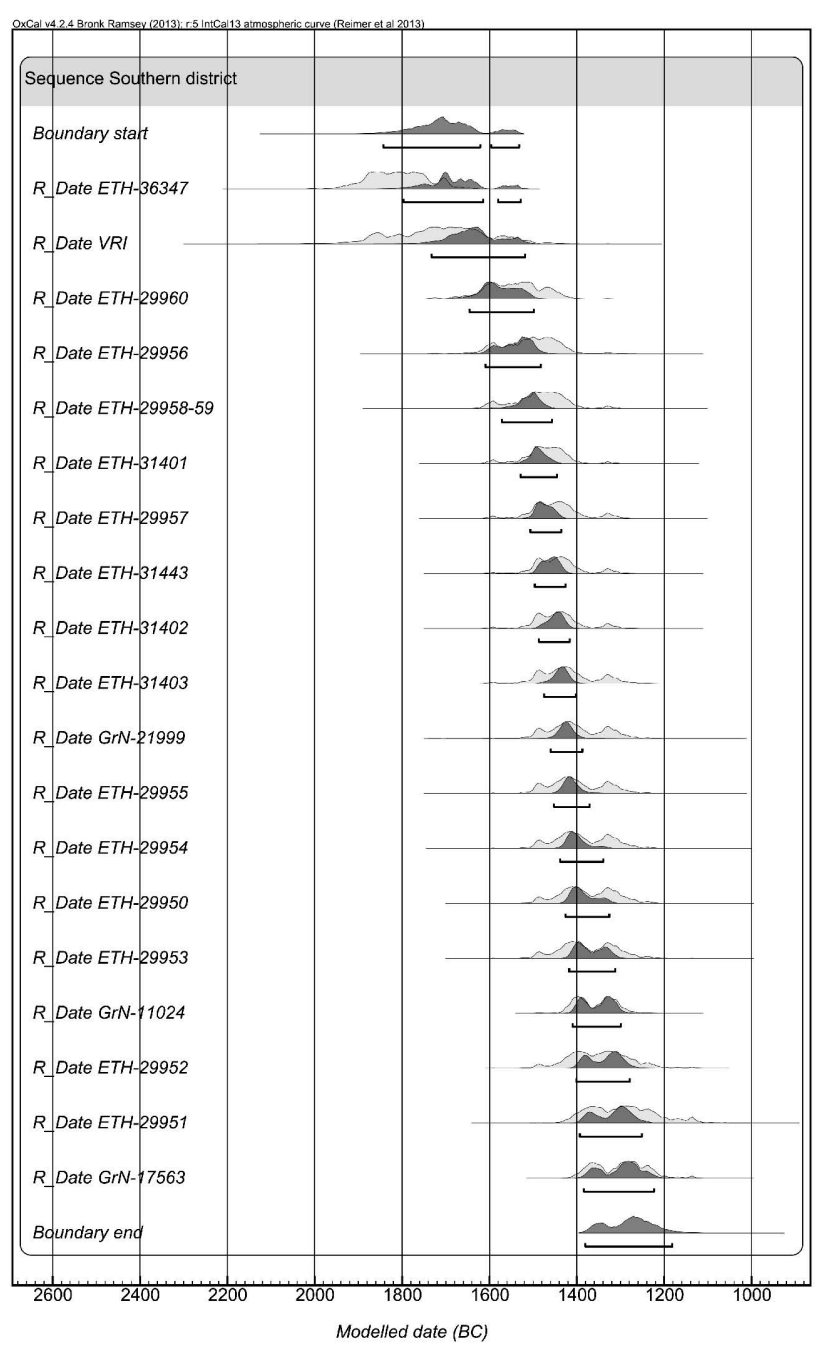

Fig. 5. Bayesian modelling of the AMS ${ }^{14} \mathrm{C}$ dates from the southern mining sector (Brander and Burgschweig lodes) (according to STÖLLnER, 2009; remodelled with OxCal v4.2.4; Bronk-Ramsey, 2013) (Deutsches Bergbau-Museum, Bochum, Ruhr-Universität Bochum, Institute of Archaeological Studies).

can be related to the eastern mining sector, especially the Buchberg lode. This would also suggest the beginning of mining operations at least in the later phases of the Early Bronze Age. ${ }^{38}$ Putting these pieces of information together, it is quite likely that mining first began east and west of the Salzach Valley before the more demanding big 'enterprise' at the remote main lode could be opened.

This underlines the importance of the Salzach Valley where we can locate various important activities. Smallscale settlements are known from various hill-top sites alongside the Salzach River, but larger settlements are still missing. They may have been buried beneath river sediments in the valley and there are indeed some indirect indications $^{39}$ of this. These include stray finds of bun ingots, a

38 LuTZ et al. 2010, see below.

39 LipPERT 1992. few graves, and also scattered indications of flat settlements may eventually revise opinion in favour of a densely settled area around Bischofshofen. ${ }^{40}$ This is made even more apparent during the later Urnfield period and the Early Iron Age by the large Pestfriedhof cemetery, ${ }^{41}$ which was probably related to contemporary mining activities at the eastern part of the Hochkeil. ${ }^{42}$ Still lacking is clear evidence for the final production steps such as the reduction of matte to blister copper as well as the alloying and casting of objects. As argued elsewhere, it is at least clear that locally used toolsets must have been produced nearby. ${ }^{43}$ The majority of the bun ingots consist of foreign fahlore and chalcopyrite copper indicating regional exchange of different copper types that may have been melted together to produce finished products for regional demand and beyond. ${ }^{44}$

In summary, the Mitterberg/Salzach-Pongau copper deposits were exploited from the $19^{\text {th }}$ or $18^{\text {th }}$ century BC onwards. The peak of copper production occurred during the later phases of the Middle and the earlier phases of the Late Bronze Age (15 th $12^{\text {th }}$ centuries $\left.\mathrm{BC}\right)$ and may have declined especially at the main lode during the middle and late Urnfield period from the $11^{\text {th }}$ century BC onwards. Nevertheless, mining continued to a certain extent into the Iron Age, when chalcopyrite copper was already being blended with fahlore-type copper (especially from the Inn Valley) on a large scale. Since intense contact with the southeastern Alpine regions is indicated by grave goods from the Pestfriedhof, it is important to ask if the mixture with fahloretype copper either from the Inn Valley or from regions south of the Alpine range became an important backbone of production in the later phases between the $10^{\text {th }}$ and the $7^{\text {th }}$ centuries BC..$^{45}$

\section{Approaches to Quantifying Production (T. Stöllner)}

It is difficult to assess the quantity of copper produced between the $18^{\text {th }}$ and $7^{\text {th }}$ centuries BC in the Mitterberg region. Since most mines are no longer accessible, it is impossible to calculate precisely the output of each mine in all periods of operation. As already mentioned, our knowledge is different in quality and quantity of dates for different mines (see Figs. 4-5). Based on radiocarbon dates from smelting sites, settlements and mining operations, we propose a Bayesian model for the southern sector and the main lode assuming that production was closely linked in both areas so that all the dates can be considered to relate to one general

40 StÖlLner et al. 2016.

41 Lippert, StAdler 2009.

42 For the mining area at the Hochmoos see Gstrein, Lippert 1988.

43 Stöllner, Schwab 2009. - Stöllner et al. 2016.

44 STÖLlNER et al. 2016.

45 See Northover 2009. 

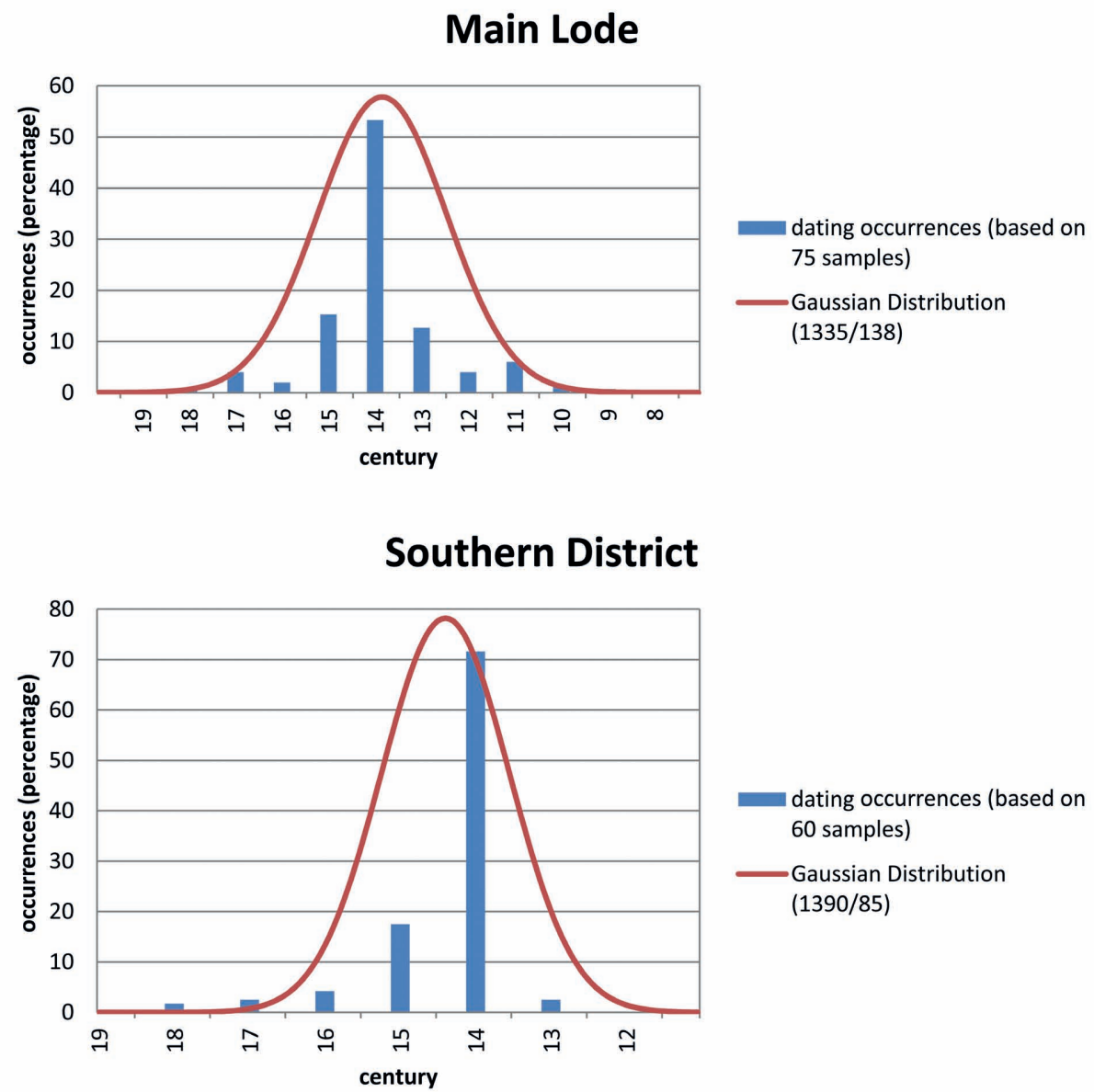

Fig. 6. Temporal sequence of centennial dating occurrences (in percentage) of the main lode and the southern sector in correlation with a Gaussian standard distribution according to the dating limits of the single mining sectors; overarching events are counted 0.5 for each of the century (Deutsches Bergbau-Museum, Bochum, Ruhr-Universität Bochum, Institute of Archaeological Studies).

period of operation. This will even allow us to model a more detailed yield of copper in different periods of operation (see Fig. 6). The number of ${ }^{14} \mathrm{C}$-dates from production sites is still too limited to support a detailed model, especially for the smaller sectors of the 'Mitterberg' region. But if we take account of all 75 dendrochronological and radiocarbon dates, we can give a rough production estimate especially for the main lode. ${ }^{46}$ The chronological sequence thus obtained

46 Seventy-five dates have been obtained from the main lode: $32{ }^{14} \mathrm{C}$ dates (see Fig. 4) and 43 dendrodates with forest edges (Sormaz, unpublished report and Nicolussi, Pichler, Thurner 2015, 239-253, esp. 239-241). This contrasts with $20{ }^{14} \mathrm{C}$ dates from the southern district (see Fig. 5) and 40 dendrodates (Sormaz, Stöllner 2009). We would like to thank all colleagues for years of mutually fruitful and trustful cooperation, especially K. Nicolussi, T. Pichler, T. Sormaz and $\mathrm{A}$. Thurner from Innsbruck and Chur. It must be mentioned that some dating sequences might well be overemphasised by the selection of samples that derive from excavation sites such as the Troiboden or the Arthurstollen gallery. is in agreement with other parameters such as the detailed pollen- and heavy-metal records in neighbouring bogs. ${ }^{47} \mathrm{As}$ described above, exact modelling is more difficult for the southern sector, and impossible for the mining sectors east of the Salzach Valley, because of an insufficient number of dates. ${ }^{48}$

If we regard the number of dates as a rough reflection of the intensity of mining, then this resembles a Gaussian distribution. There is no doubt that the most productive period at the main lode was between the $15^{\text {th }}$ and the $13^{\text {th }}$ centuries $\mathrm{BC}$ with around $70 \%$ of all measured dates falling within this timeframe (Fig. 6). A similar chronological sequence can be observed when regarding the dates so far known from the southern sector (although there are archaeological biases). When combining all currently available dates, a focal period can be assumed between the $16^{\text {th }}$ and $14^{\text {th }}$ centuries

47 BreitenleChNer et al. 2014.

48 StÖllner 2009, 44 and Fig. 6. 
Tab. 1. Estimates of copper production and losses during the various production steps in the Mitterberg district.

\begin{tabular}{|c|c|c|c|c|c|c|c|c|}
\hline & $\begin{array}{l}\text { Copper } \\
\text { content in } \\
\text { the debris }\end{array}$ & $\begin{array}{l}\text { Dry benefi- } \\
\text { ciation }(5 \%)\end{array}$ & $\begin{array}{l}\text { Wet ben- } \\
\text { eficiation } \\
(5 \%)\end{array}$ & $\begin{array}{l}\text { Dry and wet bene- } \\
\text { ficiation (analyses } \\
\text { and empirical data) } \\
1.5 \%\end{array}$ & $\begin{array}{l}\text { Amount } \\
\text { of copper } \\
\text { left }\end{array}$ & $\begin{array}{l}\text { Loss on smelt- } \\
\text { ing } 13 \%(\mathrm{em}- \\
\text { pirical data) }\end{array}$ & $\begin{array}{l}\text { Final } \\
\text { amount }\end{array}$ & Reference \\
\hline $\begin{array}{l}\text { Copper } \\
\text { production } \\
\text { main lode }\end{array}$ & 17,000 & 830 & 830 & & 15,500 & $\begin{array}{l}3900 \text { (based } \\
\text { on } 25 \% \text { loss } \\
\text { estimated from } \\
\text { analyses) }\end{array}$ & 11,600 & $\begin{array}{l}\text { Zschocke, } \\
\text { Preuschen } \\
1932\end{array}$ \\
\hline $\begin{array}{l}\text { Copper } \\
\text { production } \\
\text { main lode }\end{array}$ & 17,000 & & & 250 & 16,900 & 2200 & 14,700 & \multirow{7}{*}{$\begin{array}{l}\text { STÖLLNER, } \\
\text { HANNING, } \\
\text { HORNSCHUCH } \\
2011\end{array}$} \\
\hline $\begin{array}{l}\text { Copper } \\
\text { production } \\
\text { main lode, } \\
\text { eastern part }\end{array}$ & 1700 & & & 26 & 1700 & 220 & 1480 & \\
\hline $\begin{array}{l}\text { Copper } \\
\text { production } \\
\text { Brander } \\
\text { lode }\end{array}$ & 5300 & & & 80 & 5300 & 690 & 4600 & \\
\hline $\begin{array}{l}\text { Copper } \\
\text { production } \\
\text { Burgsch- } \\
\text { weig lode }\end{array}$ & 1100 & & & 17 & 1100 & 140 & 1000 & \\
\hline $\begin{array}{l}\text { Copper } \\
\text { production } \\
\text { Bürgstein } \\
\text { lode }\end{array}$ & 200 & & & 3 & 200 & 25 & 170 & \\
\hline $\begin{array}{l}\text { Copper } \\
\text { production } \\
\text { Buchberg } \\
\text { lode }\end{array}$ & 400 & & & 6 & 400 & 50 & 340 & \\
\hline $\begin{array}{l}\text { Copper } \\
\text { production } \\
\text { Winkel } \\
\text { lode }\end{array}$ & 800 & & & 12 & 800 & 100 & 690 & \\
\hline $\begin{array}{l}\text { Sum } \\
\text { (rounded } \\
\text { values) }\end{array}$ & 26,500 & & & 400 & 26,400 & 3400 & 23,000 & \\
\hline
\end{tabular}

$\mathrm{BC}$, and this would comprise around $80 \%$ of all measured dates (Fig. 6).

This still leaves open the question of how to achieve a reasonable calculation of the amount of copper once produced. As the mines themselves are not accessible any longer, any estimate has to be based on earlier calculations outlined by Zschocke and Preuschen. ${ }^{49}$ They started from mining debris and their copper content, which they calculated according to empirical data after nearly 100 years of modern mining. As the Mitterberg deposits did not have large oxidised enrichment zones, even near the surface, it is easier to assume an average copper content there than else-

49 Zschocke, Preuschen 1932. where. In following steps, Zschocke and Preuschen ${ }^{50}$ calculated the losses but did not base them on empirical data, preferring assumptions (e.g. in dry and wet beneficiations, in the smelting processes). It has recently been shown by analytical and taphonomic studies of beneficiation and smelting sites ${ }^{51}$ that the losses are smaller than previously assumed. This indicates better control of copper losses and greater yield of copper (see Tab. 1).

Using the new figures on copper losses, we calculate that roughly $14,700 \mathrm{t}$ of copper were produced at the main lode

50 Zschocke, Preuschen 1932, 128-135.

51 Stöllner, Hanning, Hornschuch 2011. - Hanning et al. 2013. 
Tab. 2. Estimate of copper production at the main lode and the southern sector in the context of a rough estimate outlining the temporal development of production.

\begin{tabular}{|c|c|c|c|}
\hline & $\begin{array}{l}\text { Initial period } \\
\left(18^{\text {th }}-16^{\text {th }} \text { cent. BC }\right)\end{array}$ & $\begin{array}{l}\text { Boom phase } \\
\left(15^{\text {th }}-13^{\text {th }} \text { cent. BC }\right)\end{array}$ & $\begin{array}{l}\text { Posterior phases } \\
\left(12^{\text {th }}-9^{\text {th }} \text { cent. BC }\right)\end{array}$ \\
\hline \multirow[t]{2}{*}{ Copper production, main lode district (metric tons, \%) } & $1440(10)$ & $10,600(72)$ & $2580(18)$ \\
\hline & $\begin{array}{l}\text { Initial period } \\
\left(19^{\text {th }} / 18^{\text {th }}-17^{\text {th }} \text { cent. BC) }\right.\end{array}$ & $\begin{array}{l}\text { Boom phase } \\
\left(16^{\text {th }}-14^{\text {th }} \text { cent. BC }\right)\end{array}$ & $\begin{array}{l}\text { Posterior phases } \\
\left(12^{\text {th }} \text { cent. BC to ?) }\right.\end{array}$ \\
\hline
\end{tabular}

and about $5500 \mathrm{t}$ for the Burgschweig and Brander lodes together (southern sector). In total, this means that roughly 20,000 $\mathrm{t}$ of copper were produced in the Mitterberg mining region between the $16^{\text {th }}$ and $13^{\text {th }}$ centuries (Tab. 2). This may provide a general idea about the important position that the Mitterberg deposits once had during the Middle and the beginning of the Late Bronze Age for the neighbouring regions, and even for the transregional distribution of copper.

There is no doubt that more detailed information on the periods of operation and also on further econometric parameters may influence and even alter the numbers given here. However, such calculations are certainly a step forward to arriving at a better understanding of the economic and social impact of this production centre for the European Bronze and Early Iron Age.

6. Samples and Analytical Techniques (E. Pernicka, J. Lutz) In order to obtain an overview of the chemical and lead isotope composition of the copper ores for comparison with Bronze Age metal artefacts, 95 ore samples and 12 slag samples were collected in several field campaigns in total. It must be mentioned that it is not at all easy to collect representative ore samples in such a large mining region. First, apart from the Arthurstollen, the mines are no longer accessible, so samples had to be sought in waste heaps and significant outcrops near the ancient shafts. However, the best find locations had been depleted by mineral collectors, while less-known spoil heaps are usually overgrown by vegetation and not easy to identify in the field. The samples are listed in Table $3^{52}$ and the sampling locations are roughly equally distributed between the three sub-regions shown in Figure 7. They were chemically analysed using neutron activation analysis (NAA, for $\mathrm{Fe}, \mathrm{Co}, \mathrm{Ni}, \mathrm{Cu}, \mathrm{As}$, $\mathrm{Sb}, \mathrm{Ag}, \mathrm{Au}, \mathrm{Se}, \mathrm{Te}, \mathrm{Zn}, \mathrm{Sn}$ ) and inductively coupled plasma mass spectrometry with a quadrupole ion filter (QICP-MS, for $\mathrm{Pb}, \mathrm{Bi}$ ) (Tab. 4$)^{53}$. Furthermore, the lead isotope ratios

52 Table 3 can be found on pp. $48-50$ at the end of this paper. 53 Table 4 can be found on pp. 51-53. were determined in some of the ore samples and, in addition, in some slag samples from the Mitterberg region using multi-collector ICP-MS following the procedure described by Niederschlag et al. ${ }^{54}$ The isotope ratios of lead were measured and corrected for mass discrimination by addition of $\mathrm{Tl}$. A value of ${ }^{205} \mathrm{Tl} /{ }^{203} \mathrm{Tl}=2.3871$ was taken and an exponential relationship assumed. ${ }^{204} \mathrm{~Pb}$ was corrected for the isobaric interference with ${ }^{204} \mathrm{Hg}$ by measuring ${ }^{202} \mathrm{Hg}$ and using a ${ }^{204} \mathrm{Hg} /{ }^{202} \mathrm{Hg}$ ratio of 0.2293 . The in-run precision of the reported lead isotope measurements was in the range of 0.02 to $0.08 \%(2 \sigma)$ depending on the ratio considered.

To assess the impact of the Mitterberg region on the regional supply of copper, some 800 samples of mainly Late Bronze Age prehistoric copper and bronze finds from North Tyrol, Salzburg and southern Bavaria were available. These were analysed by energy dispersive X-ray fluorescence during a research project funded by the Volkswagen foundation. ${ }^{55}$ An even larger number of chemical analyses of Early Bronze Age objects exists from central Europe. These data were obtained with emission spectroscopy and compiled during the research at the Württembergisches Landesmuseum Stuttgart. ${ }^{56}$ From the Middle Bronze Age and Early Iron Age, only few analyses have been published. The second focus of our research was to analyse bronze objects especially from the Middle Bronze Age and the Early Iron Age to close these gaps in the chronology, and to compile a substantial database for the east Alpine region with analyses of finds from the beginning of metallurgy in the Neolithic up to the Early Iron Age. About 730 objects were sampled (drill samples) and analysed using X-ray fluorescence (XRF), with selected samples also screened using NAA, QICP-MS and multi-collector ICP-MS (lead isotope ratios).

54 Niederschlag et al. 2003.

55 Sperber 2004.

56 Junghans, Sangmeister, Schröder 1968a, b, c. - Junghans, SANGMEISTER, SCHRÖDER 1974. 


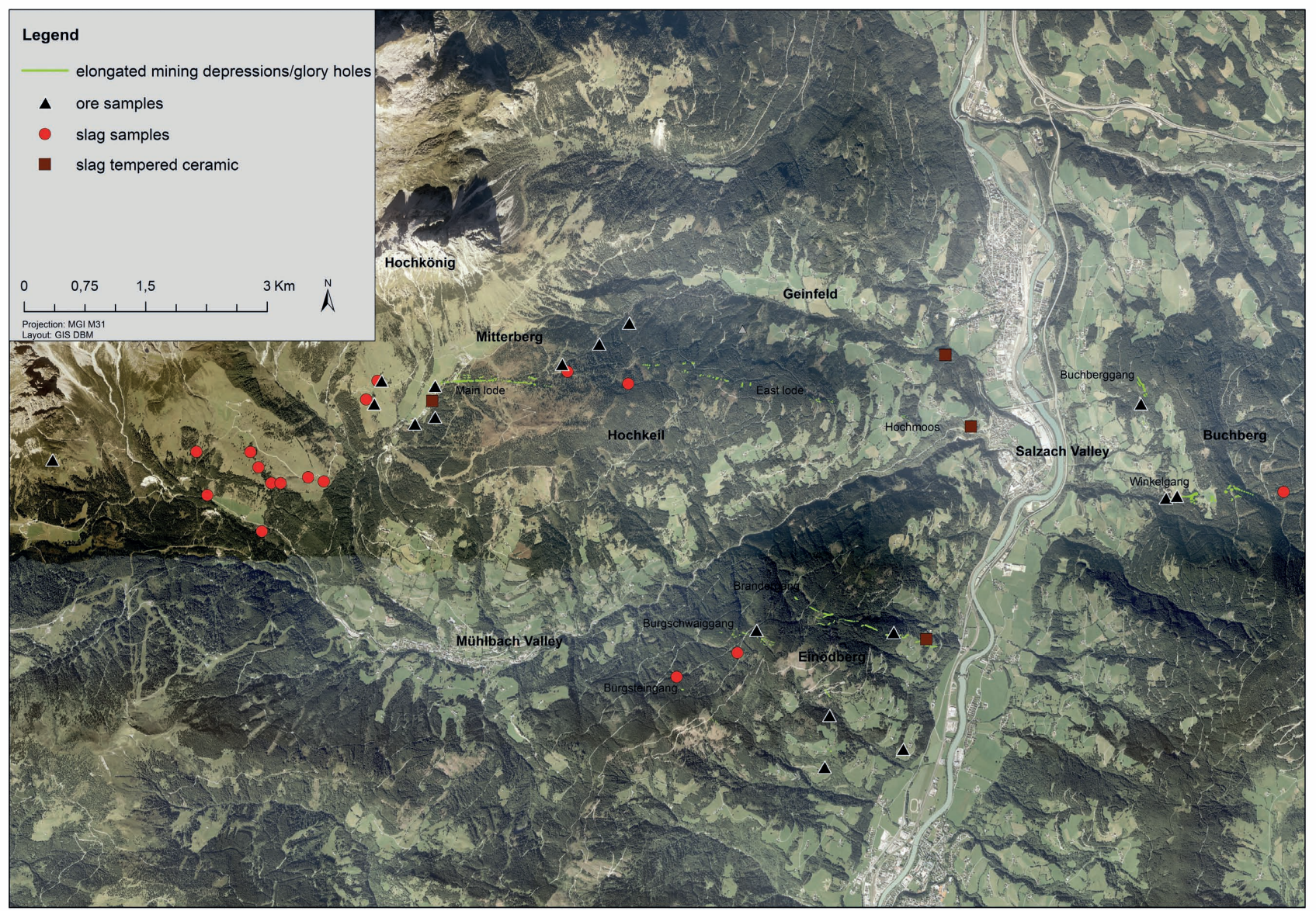

Fig. 7. The Mitterberg mining region (the mining field of Mühlbach-Bischofshofen) and its main Bronze Age mining fields (green) with the sampling locations of slag heaps, slag tempered ceramics, and ores (Deutsches Bergbau-Museum, Bochum, Ruhr-Universität Bochum, Institute of Archaeological Studies).

\section{Trace Element and Lead Isotope Patterns of the Ores}

(E. Pernicka, J. Lutz)

A major characteristic of the copper ores of the east Alpine Greywacke Zone is their generally low concentration of impurity elements. In the copper ores from the Mitterberg region only arsenic and nickel are generally present. This is due to the occurrence of gersdorffite, as is indicated by the high correlation of arsenic and nickel (Fig. 8a). In the east Alpine Greywacke Zone, two major types of copper ore are typically found: fahlores of the tennantite-tetrahedrite series $\left(\mathrm{Cu}_{12} \mathrm{As}_{4} \mathrm{~S}_{13}-\mathrm{Cu}_{12} \mathrm{Sb}_{4} \mathrm{~S}_{13}\right)$ and chalcopyrite $\left(\mathrm{CuFeS}_{2}\right) /$ pyrite $\left(\mathrm{FeS}_{2}\right)$ ores. In the Mitterberg region, fahlores do exist but only as an accessory mineral. Accordingly, the copper ores have relatively low concentrations of $\mathrm{As}, \mathrm{Sb}, \mathrm{Ag}$ and $\mathrm{Bi}$. There is only a weak correlation between arsenic and antimony at concentrations above $1 \%$ (Fig. 8b), which may indicate that these samples do contain some fahlore. Since fahlores are usually the major carriers of silver in such a mineral association, there should also be a correlation visible in the silver-antimony diagram (Fig. 8c). However, since this trend is rather weak, if present at all, the fahlore at Mitterberg seems to contain silver only in the range of $0.1 \%$ as indicated by one sample with almost $10 \%$ antimony. This is quite different from the fahlores in the Inn Valley that contain around $1 \%$ silver and often more, but it is similar to the copper ores around Kitzbühel. ${ }^{57}$

However, the chalcopyrite ores from the Mitterberg region can be differentiated from the ores from Kitzbühel-Kelchalm, which are otherwise quite similar, by their lower bismuth and selenium concentrations. Among the Mitterberg veins there are also some systematic differences that can be visualised by regarding the pattern of seven trace element concentrations (Fig. 9). For example, the Brander lode contains more cobalt and nickel than the other veins. ${ }^{58}$

The lead isotope ratios of ores from the Greywacke Zone show a large variation (especially in the Mitterberg main lode) due to generally low lead combined with

57 Christoforidis, Pernicka, Schickler 1988.

58 LuTz et al. 2010. 

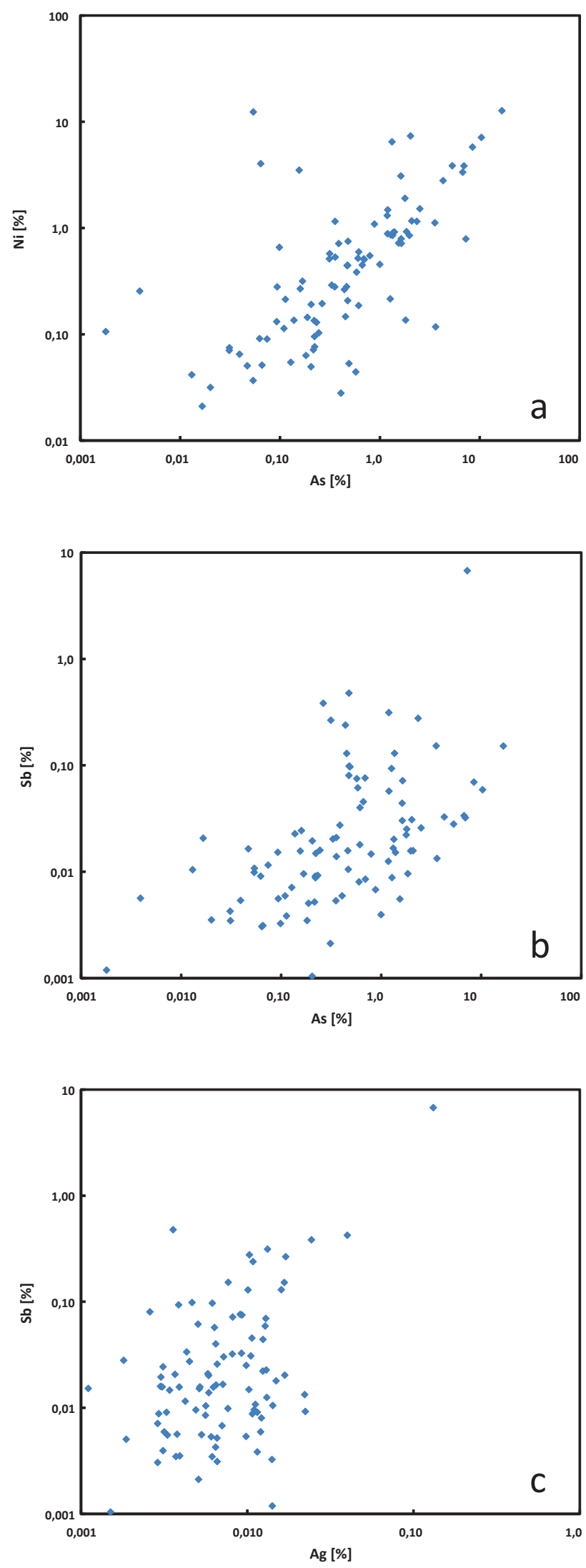

Fig. 8. Diagrams of element concentrations in the ore samples from Mitterberg, (a) As-Ni, (b) As-Sb, (c) Ag-Sb (CEZA, Mannheim). occasionally high uranium concentrations. When a mineral crystallises and incorporates lead into its crystal structure, it acquires the $\mathrm{Pb}$ isotopic composition of its parent reservoir. This is called 'common lead'. ${ }^{59}$ Since copper and lead minerals incorporate $\mathrm{Pb}$, but generally cannot accommodate uranium and thorium, the lead isotope ratios will not be changed unless subsequent processes result in the addition or loss of lead, or the addition of $U$ and Th. This is used in geology to infer a date for the formation of these crystals using the so-called 'common lead method'. In archaeometry, one simply uses the fact that lead isotope ratios in copper and lead deposits can be different and thus distinguished from each other depending on the time of their formation and the geochemical environment of their source regions.

As described above, the Mitterberg copper ores are closely associated with uranium minerals so that in an ore charge there will be 'common lead' mixed with radiogenic lead. The latter is the lead that was produced by the radioactive decay of uranium and thorium to radiogenic ${ }^{208} \mathrm{~Pb}$, ${ }^{207} \mathrm{~Pb}$ and ${ }^{206} \mathrm{~Pb}$ over the entirety of geological time up to the present. Since the mixing ratios of radiogenic and common lead can vary at the millimetre scale, each ore charge smelted may have different lead isotope ratios that vary over a large range. This is shown in Figure 10. Unfortunately, this situation is not just confined to the copper ores of Mitterberg. There are other deposits in the Old World that show a similar spread of lead isotope ratios, e.g. Rudna Glava in Serbia, ${ }^{60}$ Timna and Feinan, ${ }^{61}$ Sardinia, ${ }^{62}$ the Erzgebirge, ${ }^{63}$ and presumably many others. In an alternative diagram of the lead isotope ratios it may also be possible to distinguish between different regions, e.g. the Erzgebirge and Mitterberg (Fig. 11) which would not be possible in a diagram like in Figure 10.

For this reason it is difficult to establish a relationship between a single metal object and the Mitterberg deposits based only on lead isotope ratios. However, as we shall see below, the slope of the correlation trend may be different in different regions so that a suite of copper objects that is thought to derive from one region can, with limitations, still be related to it by lead isotope ratios. The lead of syngenetic ores from the Mitterberg region (Winkel, Buchberg, Brander, Burgschwaig and Birkstein lodes), KitzbühelKelchalm and Viehhofen is less radiogenic than the lead of the epigenetic Mitterberg main lode. In summary, we are

59 Faure, Mensing 2005.

60 Pernicka et al. 1993.

61 Hauptmann et al. 1992. - Hauptmann 2007.

62 Boni, Köppel 1985.

63 Niederschlag et al. 2003. 

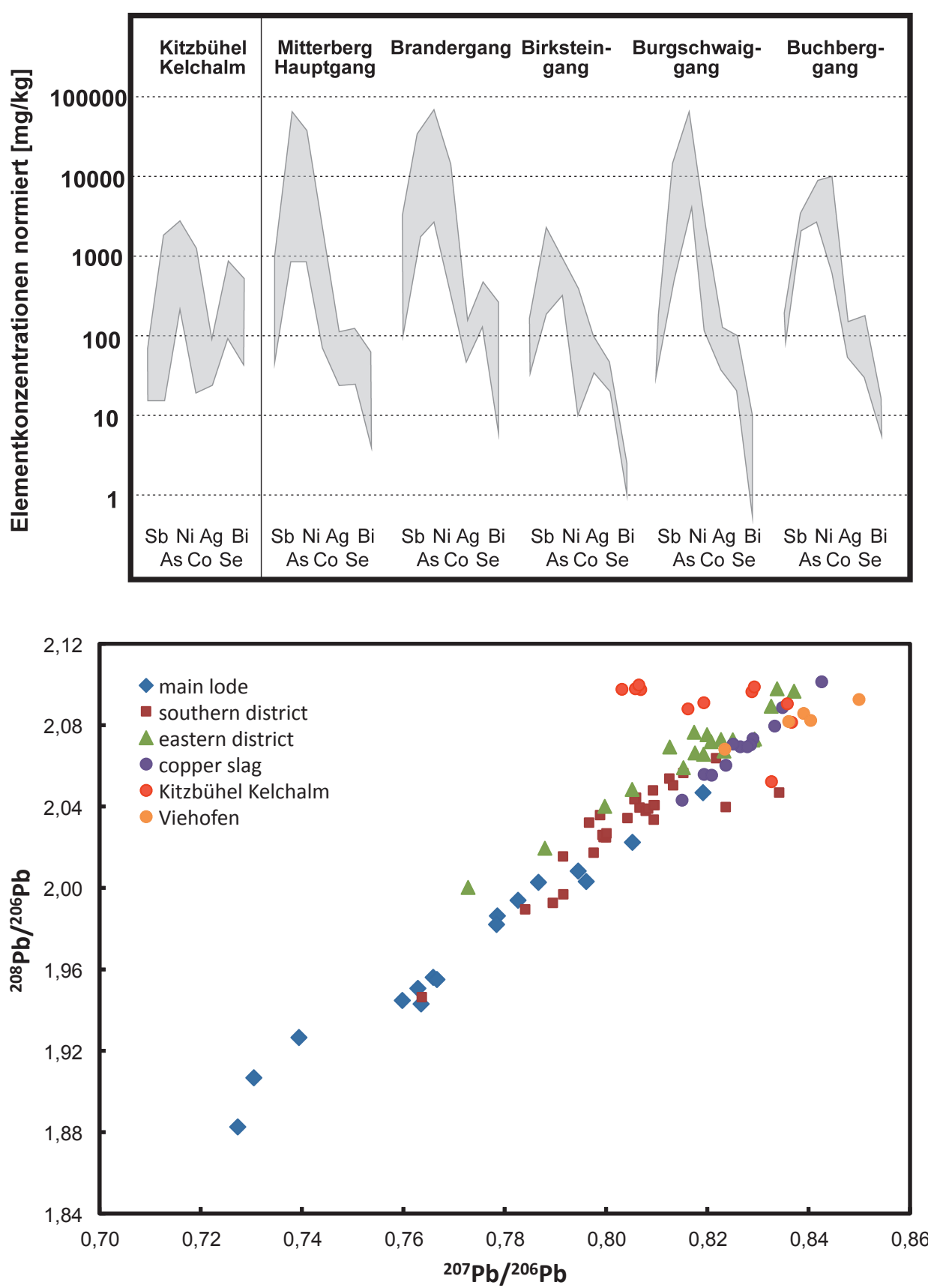

Fig. 9. Trace element patterns in ores from the Kelchalm deposit and from the Mitterberg region (several different veins). The interdecile range for some elements (Sb-As-Ni-Co-Ag-Se-Bi) is plotted on the $\mathrm{Y}$-axis in the same order. The trace element signature of the Kelchalm deposit is clearly different from the Mitterberg veins (CEZA, Mannheim).
Fig. 10: Lead isotope ratios in ores from the Mitterberg region. The ores from the epigenetic main lode are more radiogenic than the syngenetic ores from the other veins (CEZA, Mannheim). now confident that the ore deposits we have investigated up to now can be differentiated geochemically by combining trace element concentrations and lead isotope ratios.

\section{Comparison with Bronze Age Metalwork (E. Pernicka, J. Lutz)}

\subsection{The Metal Hoard from Moosbruckschrofen (Middle Bronze Age)}

This hoard (about 360 objects) is the largest metal accumulation of the Middle Bronze Age in central Europe. It was found in 2001 in a crevice of the ragged hillock Moosbruckschrofen near the town of Fliess ${ }^{64}$ and consists entirely of broken implements of various types including sickles, axes, swords, spirals, and ornamental discs in very good condition. It is interpreted as a cultic deposit rather than the accumulation of scrap metal. ${ }^{65}$ All metal objects except some black copper ingots were made of bronze and cover a range of some 200 years from the beginning to the end of the

64 Tomedi, Nicolussi Castellan, Pöll 2001.

65 Tomedi 2001. 


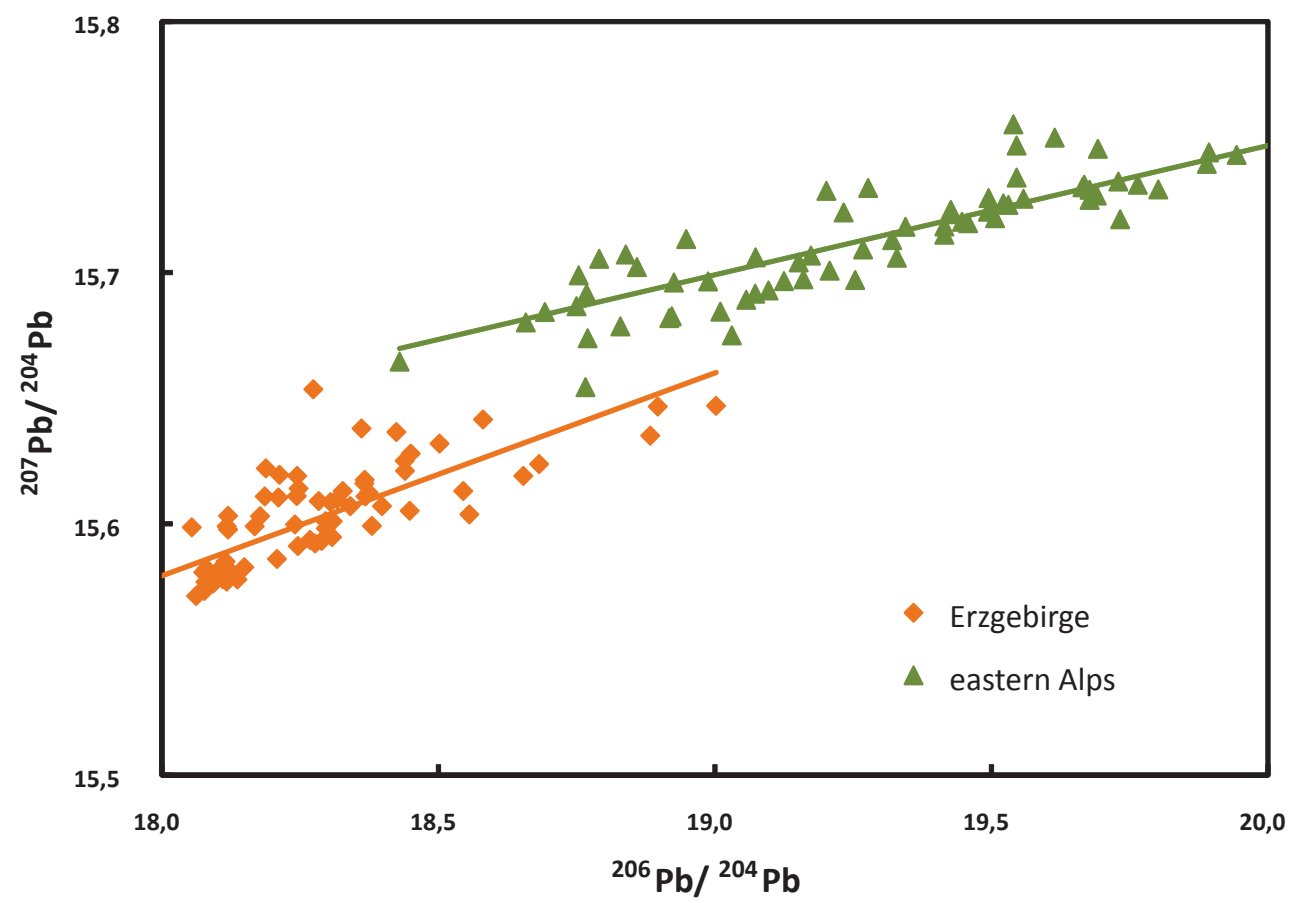

Fig. 11. Alternative diagram of lead isotope ratios in ores from the Mitterberg region compared with copper ores from the Erzgebirge (CEZA, Mannheim).
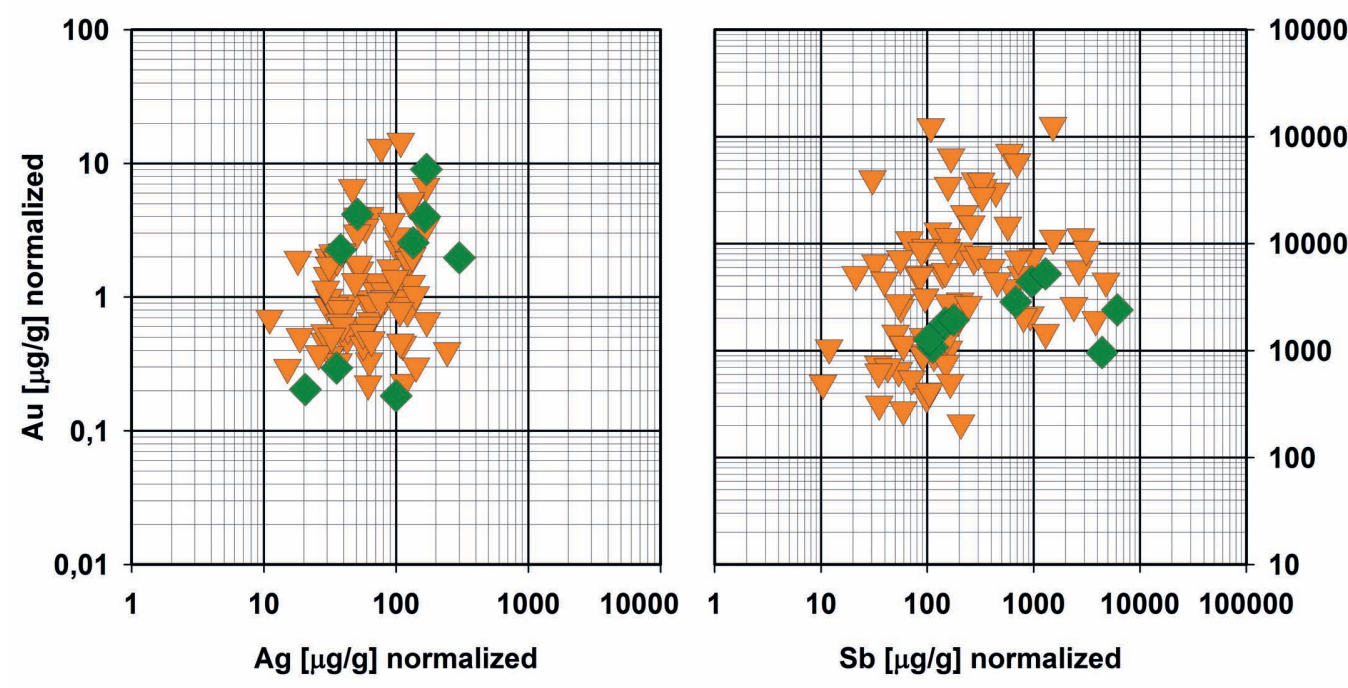

1000000

ore Mitterberg

district

copper ingots from Moosbruckschrofen hoard

Fig. 12. Trace elements in blister copper from the Moosbruckschrofen hoard compared with ores from the Mitterberg region (CEZA, Mannheim).

Middle Bronze Age. The impurity patterns of the bronzes and ingots are relatively uniform. The fragments of black copper are most suitable for provenance studies because their geochemical fingerprint was most likely not altered by alloying, mixing or recycling. The trace element analyses and lead isotope ratios of the blister copper and most of the bronze objects match the geochemical data of the ores from the Mitterberg (Figs. 12-13). Only arsenic tends to be lower than in the copper ore samples from the Mitterberg. Among the four elements considered it is the most volatile and can partly be lost on (re)melting. Actually, when considering lead isotope ratios, it is possible to be more specific and suggest the eastern sector as the most likely source of the ingot copper. Moreover, all ingots also consist of low-impurity copper consistent with the copper ores from Mitterberg. It is, therefore, impossible to decide if mixing of scrap metal 


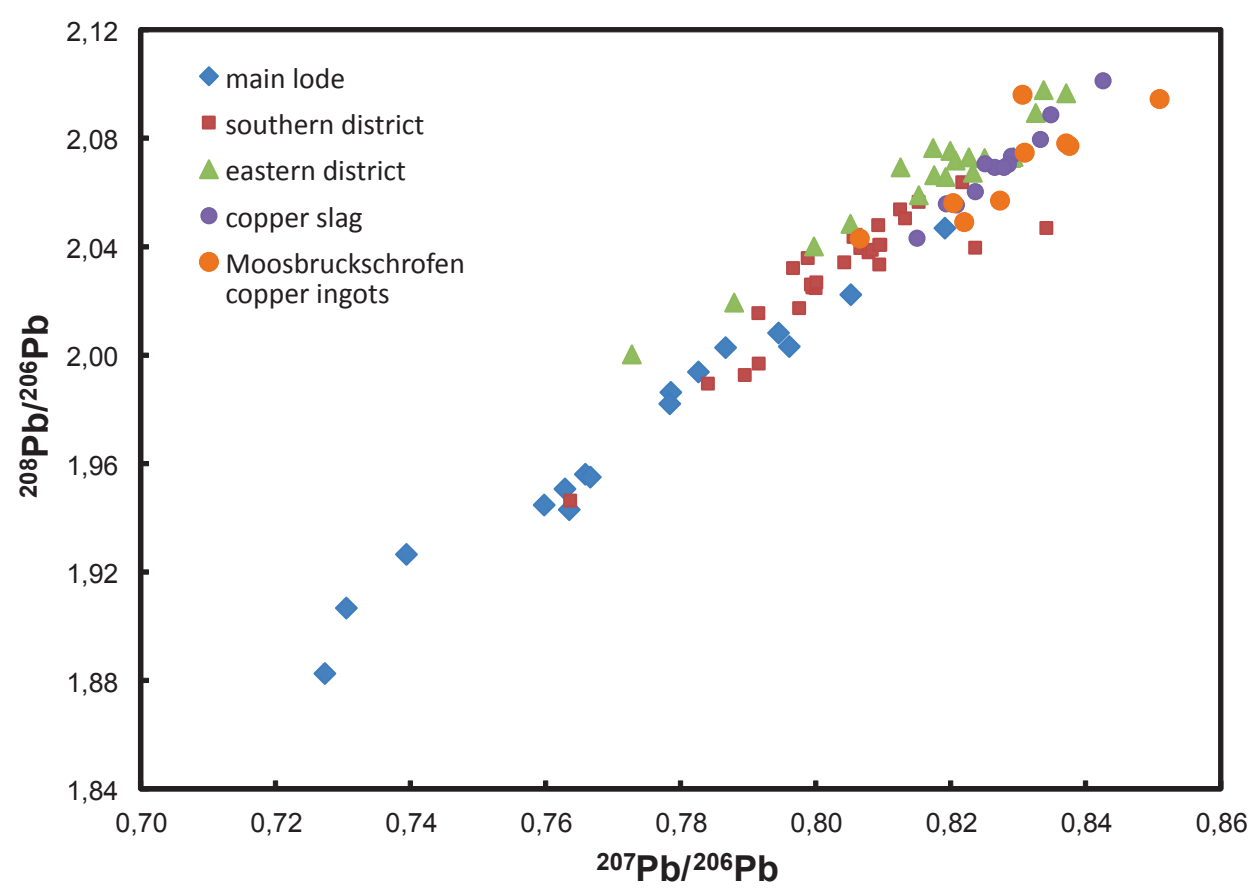

Fig. 13. Lead isotope ratios in blister copper from the Moosbruckschrofen hoard compared with ores from the Mitterberg district (CEZA, Mannheim).

had occurred or not, because on re-melting, copper from only one source would not induce any significant compositional change nor change the lead isotope ratios. If the interpretation of a cultic deposition is accepted then re-use of the metal is in any case not to be expected. Spindler even addresses the find at the Moosbruckschrofen as a 'temple hoard' and thus leaves no doubt about the symbolic character of its context. ${ }^{66} \mathrm{He}$ also dates the earliest objects of the hoard, two wing-headed pins, in agreement with Tomedi ${ }^{67}$ to around $1600 \mathrm{BC}$, which is consistent with the field observations that, in the Mitterberg region, mining began east and west of the Salzach Valley, while the main lode seems to have been opened only somewhat later.

\subsection{Late Bronze Age and Early Iron Age Finds from Southern Bavaria, Salzburg and North Tyrol}

In the 1990s, almost 800 prehistoric metal objects and ingots of black copper/fahlore copper from southern Bavaria, Salzburg and northern Tyrol were analysed within the scope of an archaeometallurgical project funded by the Volkswagen Foundation, ${ }^{68}$ including more than 70 bun-shaped ingots. About one quarter of these match the geochemical data of the ores from the chalcopyrite deposits (Mitterberg, Kelch-

66 SPINDLER 2006.

67 Tomedi 2002.

68 SPERBER 2004 alm and Viehhofen). The impurity patterns of another quarter of the ingots correspond with the fahlore deposits of the Inn Valley. In contrast to the ingots, most bronze objects show mixed impurity patterns (Fig. 14a).

There are two possible explanations for the mixed compositions. One interpretation is that metals of different compositions were mixed intentionally in order to reduce the high content of arsenic and antimony to a tolerable level and to improve forgeability. More probable is the existence of different hoarding practices. In the Late Bronze Age in central Europe and beyond, hoards of broken implements appear that often also contain broken ingots. These have commonly been interpreted as hoards of scrap metal intended to be re-used at some later time. In this case mixing would of course be unavoidable and since two major copper types were in circulation (fahlore and low-impurity copper) the result would be copper with compositions somewhere between the two end-members. Actually, there is a third possibility, namely the intentional addition of fahlore-type copper to low-impurity copper as a substitute for tin as suggested by inverse trends of tin concentrations compared with those of antimony and silver, especially in the later phases of the LBA. ${ }^{69}$ The reason might be a shortage of tin due to increased demand of metal.

69 StÖLlner et al. 2016. - For Swiss metals see Sperber 2004, 330 and Tab. 3. 


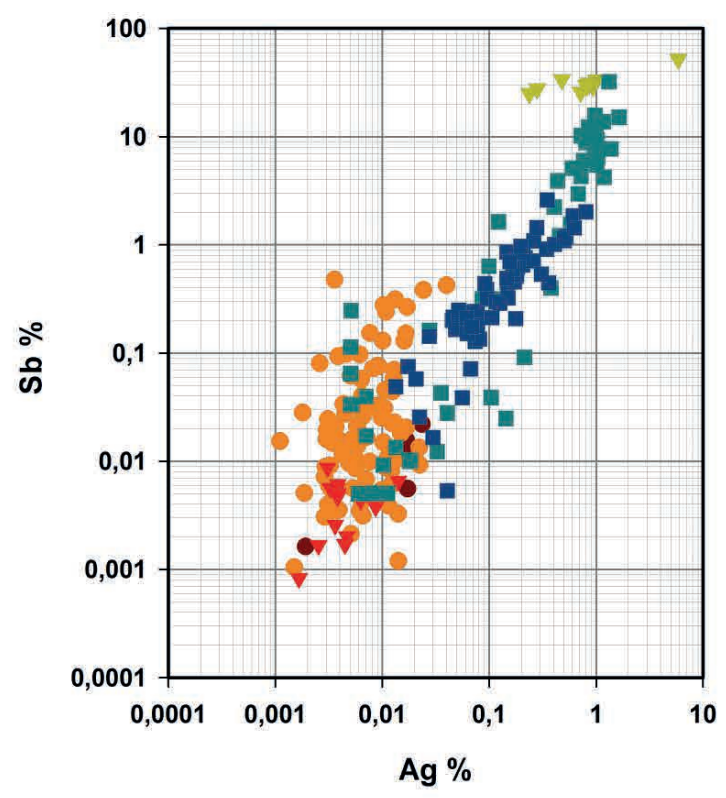

A ore Viehhofen

- ore Mitterberg district

$\nabla$ ore Schwaz/Brixlegg

$\nabla$ ore Kitzbühel-Kelchalm

- black copper/fahlore copper (Late Bronze Age, Ha A-B)

- bronze objects (Late Bronze Age, Ha A-B)

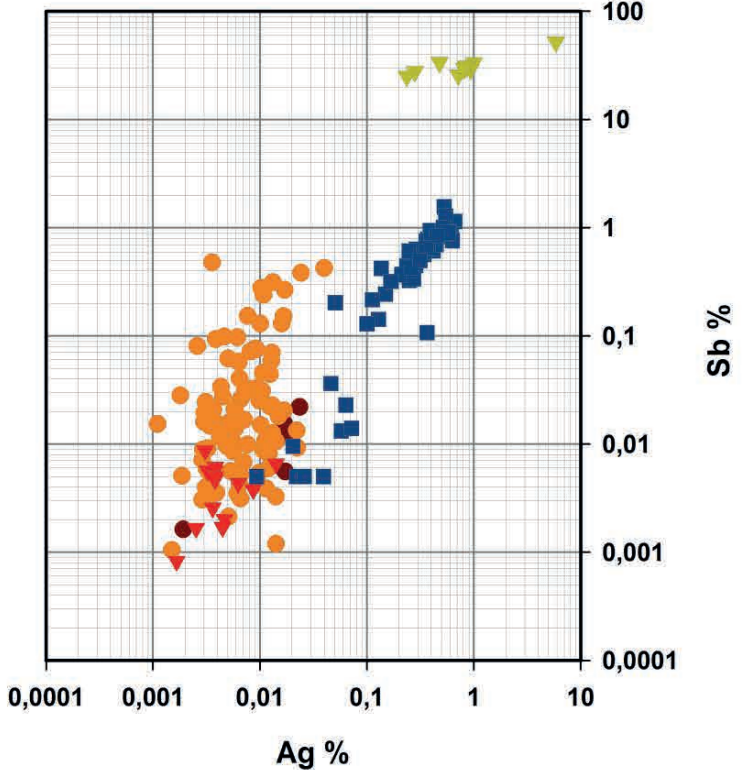

B ore Viehhofen

ore Mitterberg diestrict

ore Schwaz/Brixlegg

$\checkmark$ ore Kitzbühel-Kelchalm

bronze objects Fliess (Early Iron Age, Ha C-D)

Fig. 14. Concentrations of silver and antimony in fahlores from the Inn valley Schwaz/Brixlegg) and in chalcopyrite ores from Mitterberg, Kitzbühel and Viehhofen compared with LBA ingots and bronze objects from Tyrol, Salzburg and southern Bavaria (a) and Early Iron Age bronze objects from Fliess (b). While the ingots largely reflect the different compositions of the ores, the bronze objects predominantly plot between the two clusters of copper ores indicating mixing (CEZA, Mannheim).

The effect of mixing is seen in Figure 14a. The copper ingots with a fahlore signature (black copper) contain less antimony than the ores, which is due to the fact that substantial parts of arsenic and antimony are lost on smelting fahlores..$^{70}$ Otherwise, only a few of the ingots show mixed signatures. Quite the opposite is true for the bronze objects, which exhibit predominantly mixed compositions.

This pattern is retained in the Early Iron Age hoard of Fliess as shown in Figure 14b. This hoard was discovered in 1990 during construction works in the town of Fliess and comprises 385 bronze objects dated to the $7^{\text {th }}$ and $6^{\text {th }}$ centuries $\mathrm{BC} .^{71}$ It was investigated because little evidence existed for mining and extractive metallurgy in the east Alpine region in this period. It is unknown whether the decline at the end of the Bronze Age is real or merely a gap in archaeometallurgical research. The hoard contains many types such as brooches that can be identified as imports from distant regions, but also implements like winged axes, chisels, saws, and files that can be attributed to local production. The latter are plotted in Figure 14b and again show predominantly mixed compositions between fahlore signature and low-impurity copper.

70 Pernicka 1999.

71 Sydow 1995.

\subsection{Transregional Distribution of Mitterberg Copper}

The Early Bronze Age Nebra hoard, which comprises the Nebra Sky Disk, two bronze swords decorated with gold cuffs, two flanged bronze axes, two bronze arm spirals and one bronze chisel, was discovered during an illegal excavation in 1999 on the Mittelberg in southern Sachsen-Anhalt, central Germany. Scientific investigations of the hoard and particularly of the Sky Disk initially concentrated on authentication by mineralogical, trace element and lead isotope analyses of the bronze, the mineralogical and chemical composition of the corrosion layer and soil adhesions, and the technology of manufacture. ${ }^{72}$ More detailed investigations on the manufacturing technique were published by Berger and colleagues ${ }^{73}$ including the study of the $0.1-0.4 \mathrm{~mm}$ thin gold sheets that had been plated and punched onto the bronze disk, which measures about $32 \mathrm{~cm}$ in diameter. The gold inlays have been interpreted as a sun or full moon, a crescent-shaped moon, and 32 stars. Two of the stars were removed and the position of a third was changed when two horizon arches were later attached to the disk, followed by

72 Pernicka, Wunderlich 2002. - Pernicka et al. 2008. - PerNICKA 2010

73 Berger, Schwab, Wunderlich 2010. 

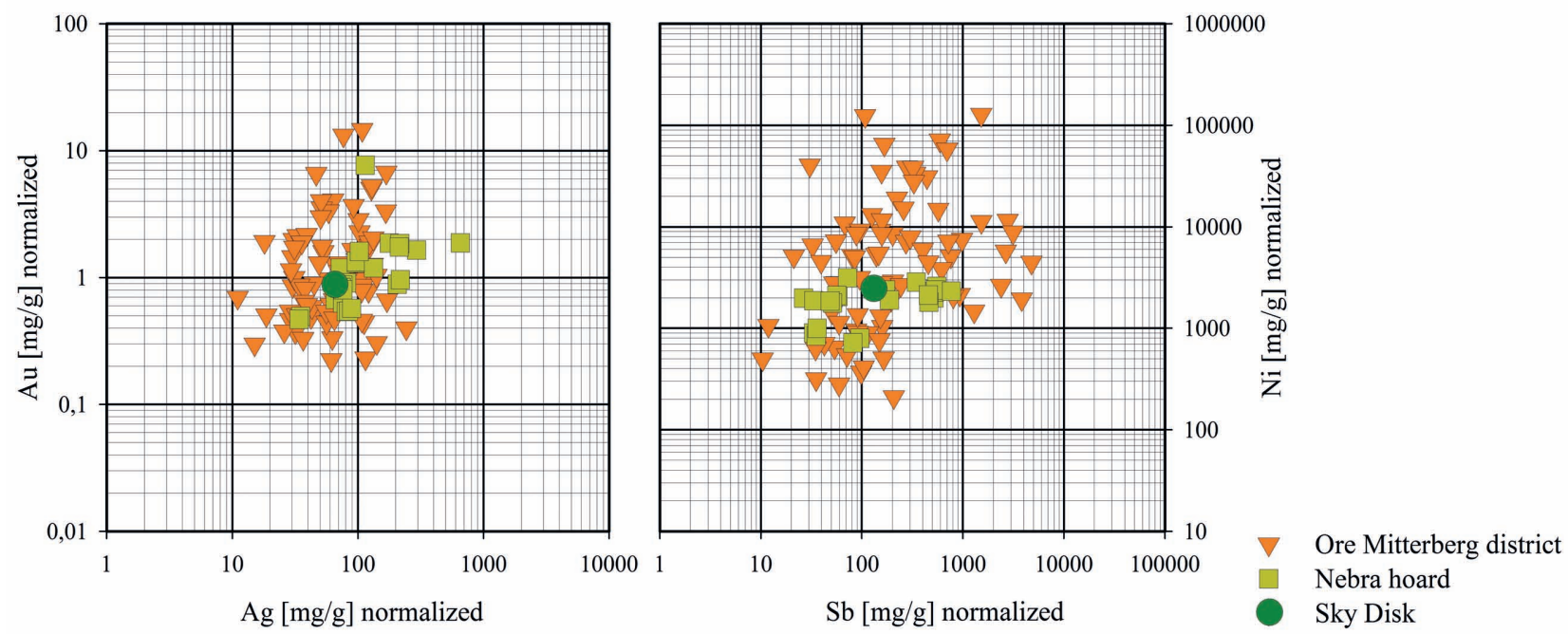

Fig. 15. Trace elements in ores from the Mitterberg region and in finds from the Nebra hoard (CEZA, Mannheim).

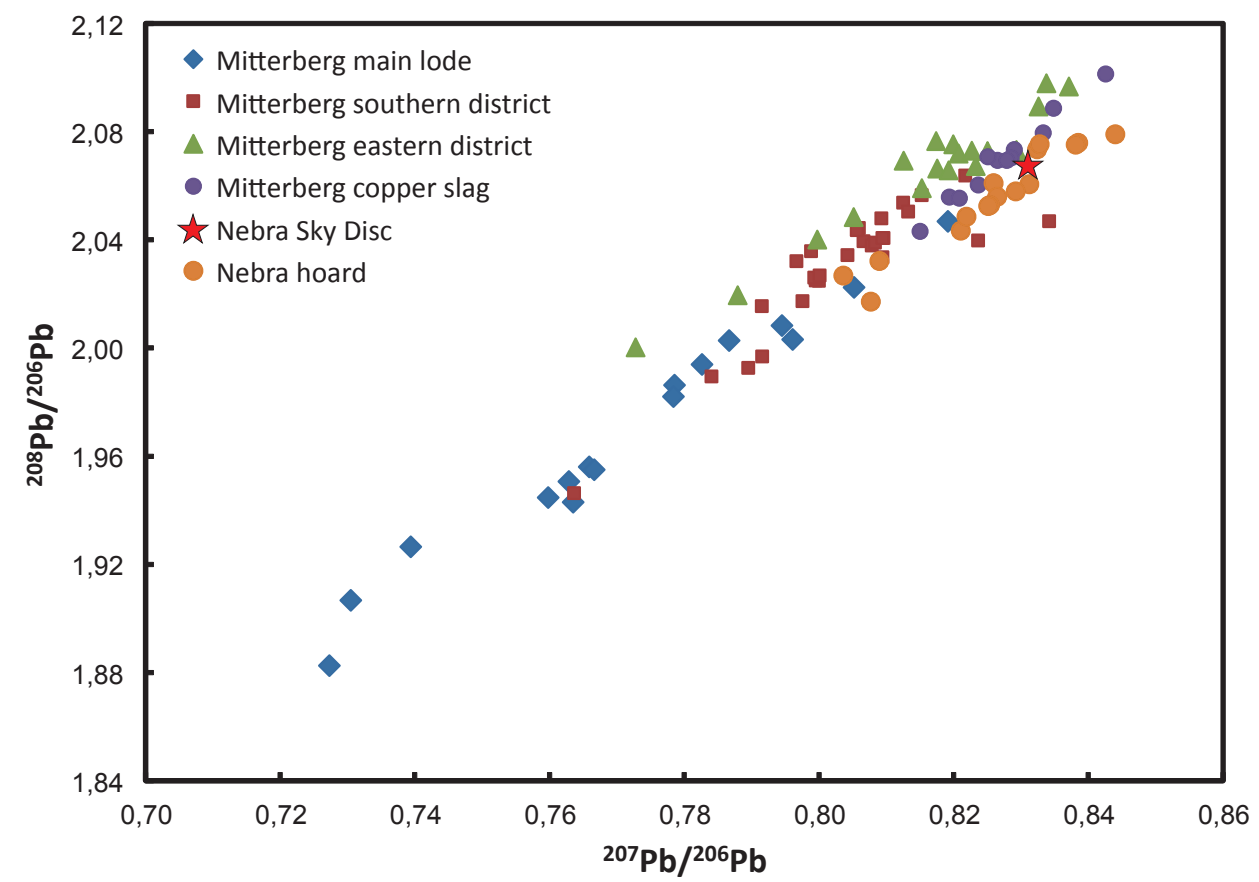

Fig. 16. Lead isotope ratios in ores and prehistoric slag from the Mitterberg region compared with the Nebra hoard and the Sky Disk of Nebra (CEZA, Mannheim).

the final attachment of a boat or barge. ${ }^{74}$ The constellation of the gold inlays suggests that the disk initially may have been used for calendrical purposes, ${ }^{75}$ making the Nebra Sky Disk the earliest astronomical representation of the night sky.

The archaeological context of the Sky Disk can be deduced from the accompanying finds in the hoard, which can all be dated to the developed Early Bronze Age in central Europe around $1600 \mathrm{BC}$, the end of the classical Únětice

74 Meller 2010.

75 SChlosser 2003.
Culture. This date of burial of the hoard was confirmed by ${ }^{14} \mathrm{C}$ analyses of a small piece of birch bark found in the handle of a sword. However, the date of manufacture of the $\mathrm{Ne}$ bra Sky Disk remains unknown due to the lack of a suitable physical method for dating metal objects.

The trace element patterns of all objects of the Nebra hoard exhibit an excellent match with the new data of the ores from the Mitterberg (Figs. 15-16). The lead isotope ratios of the metal finds also correspond very well with the slag samples from the Mitterberg area. There is a marginal 


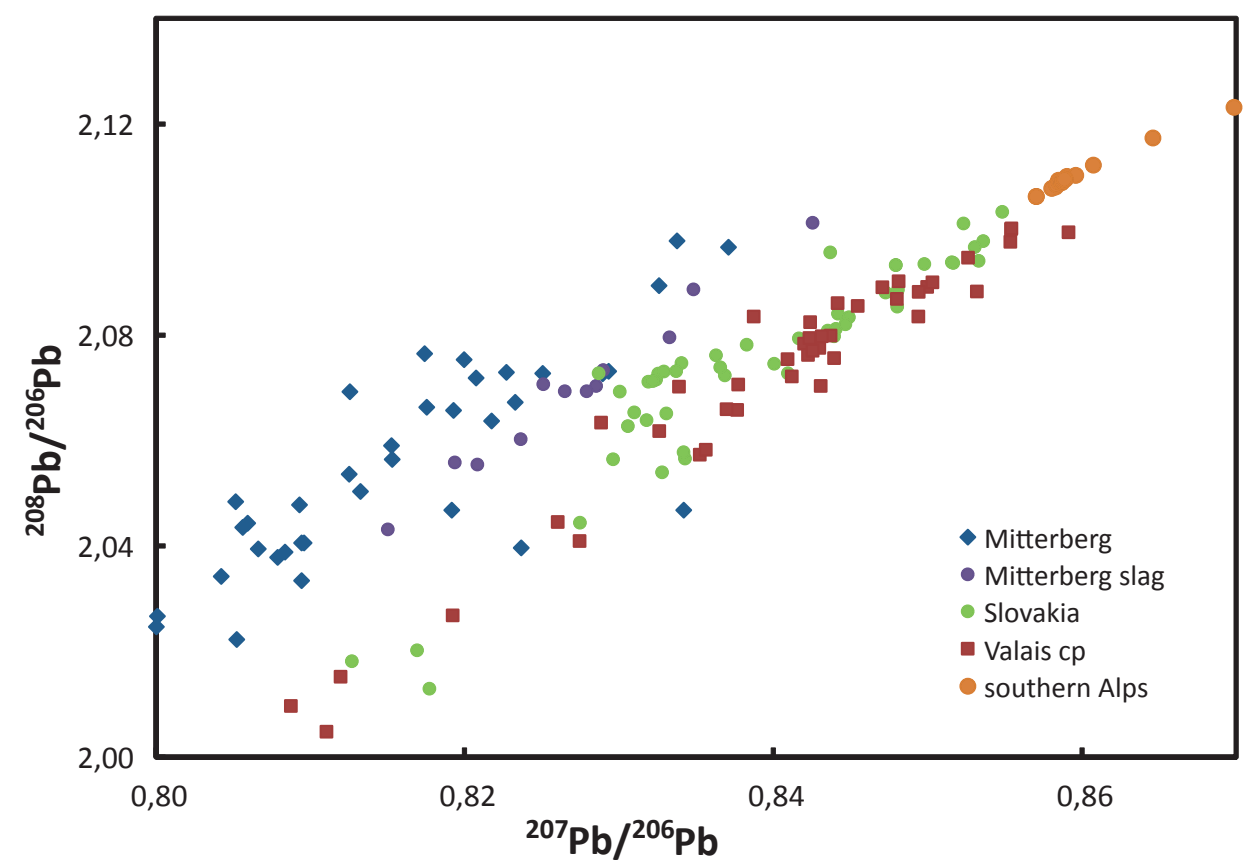

Fig. 17. Lead isotope ratios of the Mitterberg region (eastern Alps) compared with copper ores from the Hron Valley in Slovakia (SCHreIner 2007), Eneolithic copper smelting slags from Trentino and Alto Adige (Artioli et al. 2015) chalcopyrite ores from the Valais in Switzerland (CATTIN et al. 2011). The latter two data sets could be further differentiated by the ${ }^{206} \mathrm{~Pb} /{ }^{204} \mathrm{~Pb}$ ratio but this is not relevant in this context (CEZA, Mannheim).

systematic difference between the lead isotope ratios of the ores and the slag samples (Tabs. 5-6 $)^{76}$. The reason might be a different lead isotopic signature of additional fluxes used in the smelting process, or the separation of uranium phases and radiogenic lead while processing the ores (milling, washing). Furthermore, the validity of the relationship between copper ores from the Mitterberg region and the $\mathrm{Ne}$ bra hoard is strongly corroborated by the finding that most copper deposits in Germany and the Czech Republic have different lead isotope ratios as was shown by Frotzscher. ${ }^{77}$ Recently published results of lead isotope analyses of copper ores from the Valais in Switzerland, ${ }^{78}$ the Hron Valley in Slovakia ${ }^{79}$ and the Trentino in Italy ${ }^{80}$ are also different (Fig. 17). Accordingly, the combination of trace-element pattern and lead isotope ratios of the Mitterberg ores can be considered more or less unique among the copper deposits in central Europe. It is characterised by nickel and arsenic as major impurities that usually occur in roughly equal concentrations and by generally low silver concentrations below $0.05 \%$.

76 Tables 5-6 can be found on pp. 54-55 at the end of this paper.

77 Frotzscher 2009.

78 CATtin et al. 2011.

79 SCHREINER 2007.

80 Artioli et al. 2015.
The wider distribution of the Mitterberg copper was investigated by comparing the trace element pattern of the ores with a large database of chemical analyses of prehistoric metal objects in Europe and the Mediterranean region, dating mainly from the early metal ages, i. e. earlier than roughly $1500 \mathrm{BC}$. The core of this database is formed of the analyses performed at the Württembergisches Landesmuseum in Stuttgart with atomic emission spectrometry, ${ }^{81}$ to which analyses performed with neutron activation and X-ray fluorescence were added. It was shown that the Stuttgart data are essentially accurate and can, therefore, be pooled and classified together. ${ }^{82}$ Cluster analysis of some 25,000 datasets based on the element concentrations of $\mathrm{As}, \mathrm{Sb}, \mathrm{Ni}, \mathrm{Ag}$, and $\mathrm{Bi}$ has largely confirmed the earlier classification of the Stuttgart team..$^{83}$ In the present context, this database was used in a different way in that similar patterns in mean values of $\mathrm{As}, \mathrm{Sb}, \mathrm{Ni}$, and $\mathrm{Ag}$ in the objects from the Nebra hoard were searched for. Two search intervals were used. First, the mean values were multiplied by a factor of \pm 2 , and in a second run by a factor of \pm 4 as already successfully applied by

81 Junghans, SAngmeister, Schröder 1960. - Junghans, SAngMEISTER, SCHröDER 1968a, b, c. - Junghans, SANgmeISTER, SchröDER 1974.

82 Pernicka 1984.

83 Pernicka 1990. 


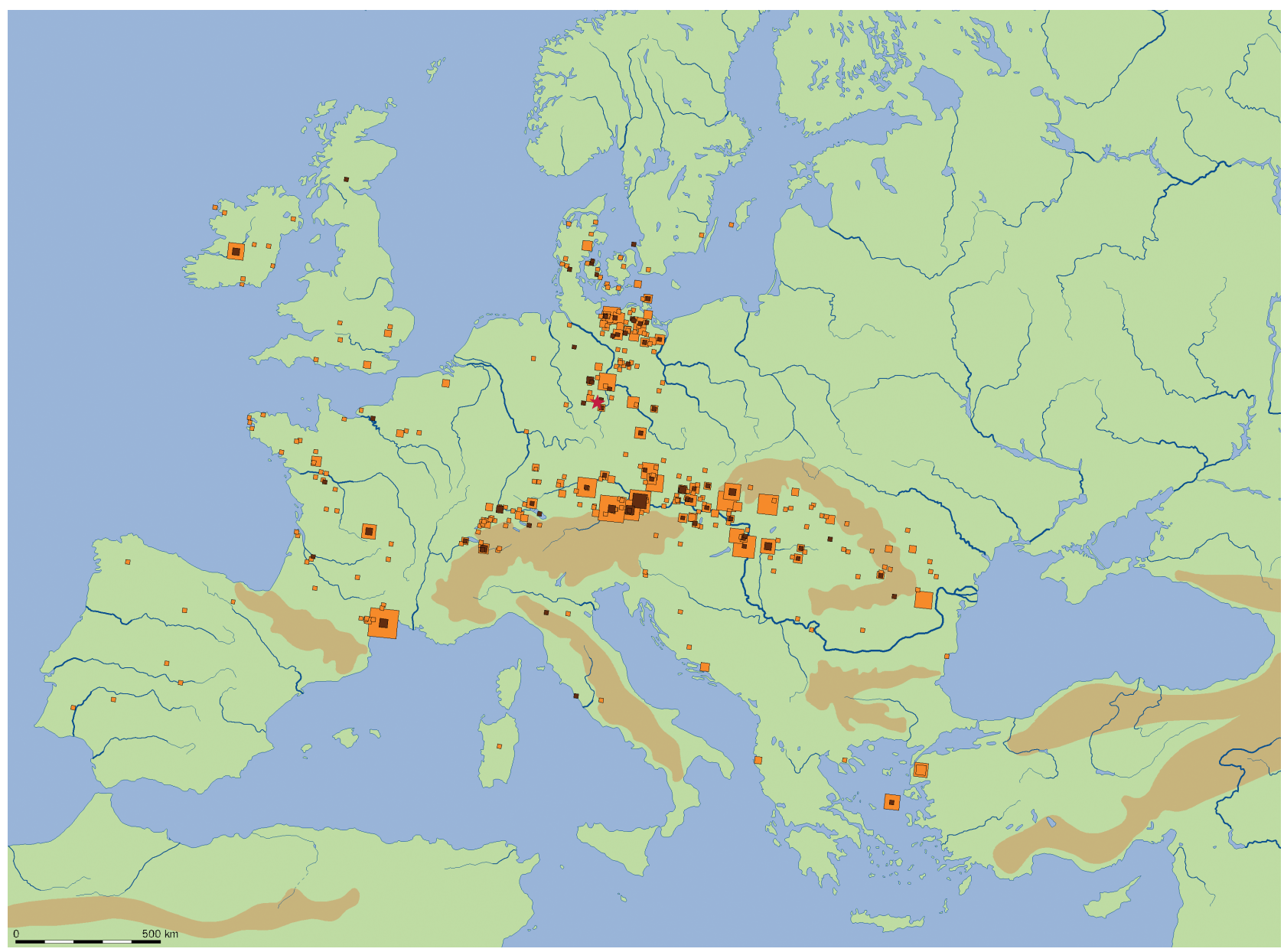

Fig. 18. Distribution of metal objects dating to the Early Bronze Age with similar trace element patterns as the Nebra hoard. The size of the symbols relates to the number of objects at each site. The red symbols indicate the smaller search interval and the yellow symbols the larger one (see text for explanation) (CEZA, Mannheim).

Klassen and Pernicka. ${ }^{84}$ The narrow interval represents the rather low precision of the Stuttgart data of around $\pm 30 \%$ relatively. ${ }^{85}$ Thus, if the mean value of e.g. arsenic is $0.214 \%$, then the search interval was between 0.107 and $0.428 \%$ and similarly for the remaining elements. With this interval, objects which had exactly the same trace element pattern as the Nebra hoard (that derived its copper from the Mitterberg region as has been shown above) would be identified. The larger interval allows a difference of a factor of 16 between the lower and upper limit. However, since the trace element concentrations in ore deposits usually range over more than one order of magnitude, this filter would still detect objects that may derive from the same type of copper deposit. The result for roughly contemporary finds to the Nebra hoard is shown in Figure 18.

84 Klassen, Pernicka 1998.

85 PERNICKA 1984
It may be noted in passing that such a result would not have been possible with the classification method that was suggested by Bray et al., ${ }^{86}$ who simply regard the 'presence' or 'absence' of the elements $\mathrm{As}, \mathrm{Sb}, \mathrm{Ag}, \mathrm{Ni}$ as important. As a dividing line, they arbitrarily define a concentration of $0.1 \%$ for all these elements. With this approach, the Mitterberg ores would be divided into two or three different compositional groups. It is interesting that this concept was already unsuccessfully proposed by Richard Pittioni $i^{87}$ who used semiquantitative analyses with a detection limit of about $0.001 \%$ for these elements, which is geochemically and metallurgically more justified. Nevertheless, numerous studies, not least the one by the Stuttgart team themselves, have shown that it is not only worthwhile but essential to use multivariate statistics to extract usable information

86 Bray et al. 2015.

87 Pittioni 1959. 


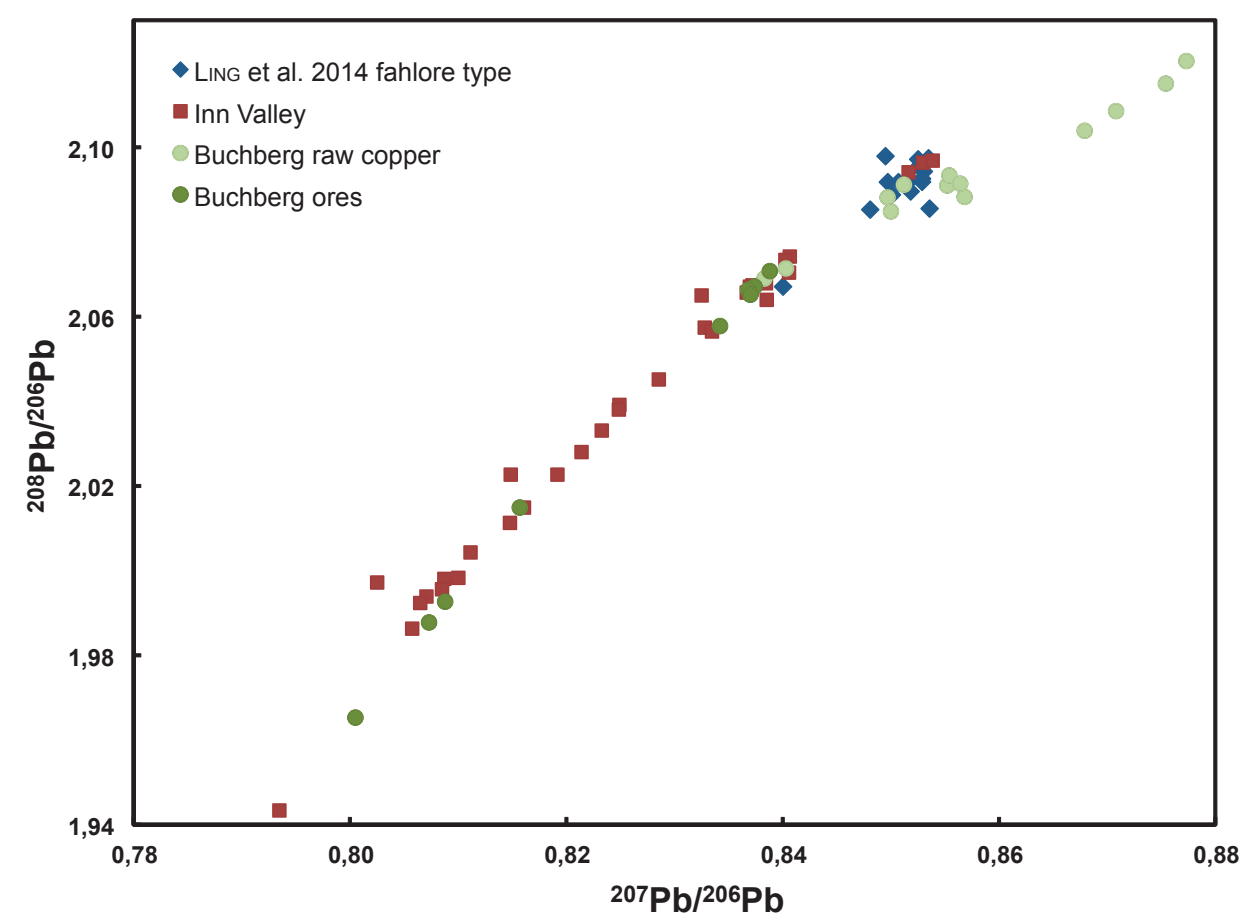

Fig. 19. Lead isotope ratios of Swedish copper objects with a fahlore signature (Ling et al. 2014) compared with fahlore samples from the Inn Valley between Innsbruck and Brixlegg (HöppNER et al. 2005) and copper ores and raw copper from the Early Bronze Age site of Buchberg near Brixlegg (SCHUBERT, Pernicka 2013) (CEZA, Mannheim).

from quantitative multi-element analyses. Equally so, the compositional classification by Bray et al..$^{88}$ does not stand up to the complexity of the data with the simplified yes/no presence of trace-element concentrations and an unsubstantiated threshold arbitrarily set at $0.1 \mathrm{wt} \%$ without any geochemical or metallurgical justification. Moreover, it proves the case that classification of continuous data with a discontinuous method is inappropriate and does not advance the scientific interpretation of an existing set of archaeometallurgical data. Last but not least, it is impossible to identify metal recycling patterns with such a method, and in effect the models based on this methodology are producing incorrect patterns of human behaviour. The weakness of this approach is also exemplified by Perucchetti et al., ${ }^{89}$ which produced a much more confused distribution of compositionally different Chalcolithic and Bronze Age copper objects from the distribution maps by Junghans et al. and Spindler, ${ }^{90}$ and practically without any new insights.

Although the comparisons are based only on the trace-element patterns, it is evident from Figure 18 that there can be no doubt that the Mitterberg region was an im-

88 Bray et al. 2015.

89 Perucchetti et al. 2015.

90 Junghans et al. 1968. - SPINDLER 1971. portant source for copper in prehistoric central Europe. A detailed discussion of this distribution map is still pending but the two large symbols in Hungary east of the Danube and in northwest Romania are the hoards of Hajdúsámson and Apa, which are consistent with Mitterberg copper in their trace element patterns as well as in their lead isotope ratios ${ }^{91}$ indicating the flow of this metal type from the Alpine piedmont into the Carpathian basin in the east and into western France along the Saone River in the west.

A second agglomeration of data points along a route towards the north to southern Scandinavia is also prominent.

There are very few lead isotope ratios available for Bronze Age metal objects from this region, but a few dozens were published by Ling and colleagues in 2013 and again with some additional analyses in $2014^{92}$ together with major and trace element compositions obtained with electron microprobe analysis. The dates of this sample suite range from the Late Neolithic II to Period V according to the relative chronology of northern Europe, ${ }^{93}$ i. e. from about 2000 to $700 \mathrm{BC}$ in absolute terms. These authors have attempted to identify the ore sources of the prehistoric metal objects

91 Pernicka 2013. - Pernicka et al. 2016.

92 Ling et al. 2013. - LiNg et al. 2014.

93 Kristiansen 1998. 
found in Sweden based only on lead isotope ratios, and came to the conclusion that the majority of the objects derived their copper from Mediterranean sources (southern Iberia, Sardinia, Laurion in Attika, Greece, and Cyprus) but 17 out of 71 objects were attributed to North Tyrol, while Swedish copper ores could be excluded.

The problem with such affirmative assignments is that there are many copper mineralisations in such a large area like the whole of Europe and the Mediterranean, so there is bound to exist an overlap of the lead isotope ratios of various ore deposits. It would therefore be necessary to check if the chemical composition of the proposed ore sources were also consistent with such assignments. For the objects related to Brixlegg in North Tyrol it is mentioned that, in addition to matching lead isotope ratios, the objects contain high percentages of silver, arsenic and antimony, i. e. a fahlore signature that resembles the Ösenring copper of the central European Early Bronze Age. ${ }^{94}$ However, this chemical match is by no means perfect as the Ösenring copper typically also contains $0.1 \% \mathrm{Bi}$, which should be measurable with an electron microprobe. However, this element is not reported. Instead, gold concentrations between 0.01 and $0.12 \%$ are listed in Ling and colleagues in 2013 but not in 2014, ${ }^{95}$ while Höppner et al. ${ }^{96}$ did not detect any gold in the Ösenring samples analysed. Moreover, $96 \%$ of about 2700 analyses of Ösenringe in the Stuttgart project contain less than $0.1 \%$ lead, which is corroborated by Höppner et al. who reported less than $0.01 \%$ lead in all the Ösenring samples analysed from Gammersham, Bavaria. ${ }^{97}$ On the other hand, only two out of sixteen Swedish copper objects with a fahlore signature contain less than $0.1 \% \mathrm{~Pb}$, while the others contain between 0.2 and $1.3 \% \mathrm{~Pb}$. One rod of lead is even assigned to the Tyrol, although there are no lead deposits in the Inn Valley. There is nevertheless a chance that this type of copper derives from the Tyrol, because there is a match with three ore samples from the Triassic limestone unit, which has been much less investigated than the regional dolomite ores and with copper spills from the Early Bronze Age smelting site at Buchberg in the Inn Valley (Fig. 19). ${ }^{98}$

If we accept for the moment that copper from central Europe reached Sweden in the second millennium BC, then the question is why this should not also be true for Mitterberg copper, especially because the pattern of metal supply within this period is rather similar in central Europe and

94 LiNG et al. 2014.

95 LiNG et al. 2013. - LiNG et al. 2014.

96 HöPPNER et al. 2005.

97 HöPPNER et al. 2005.

98 Martinek 1996. - Sydow 1996. - Schubert, Pernicka 2013.
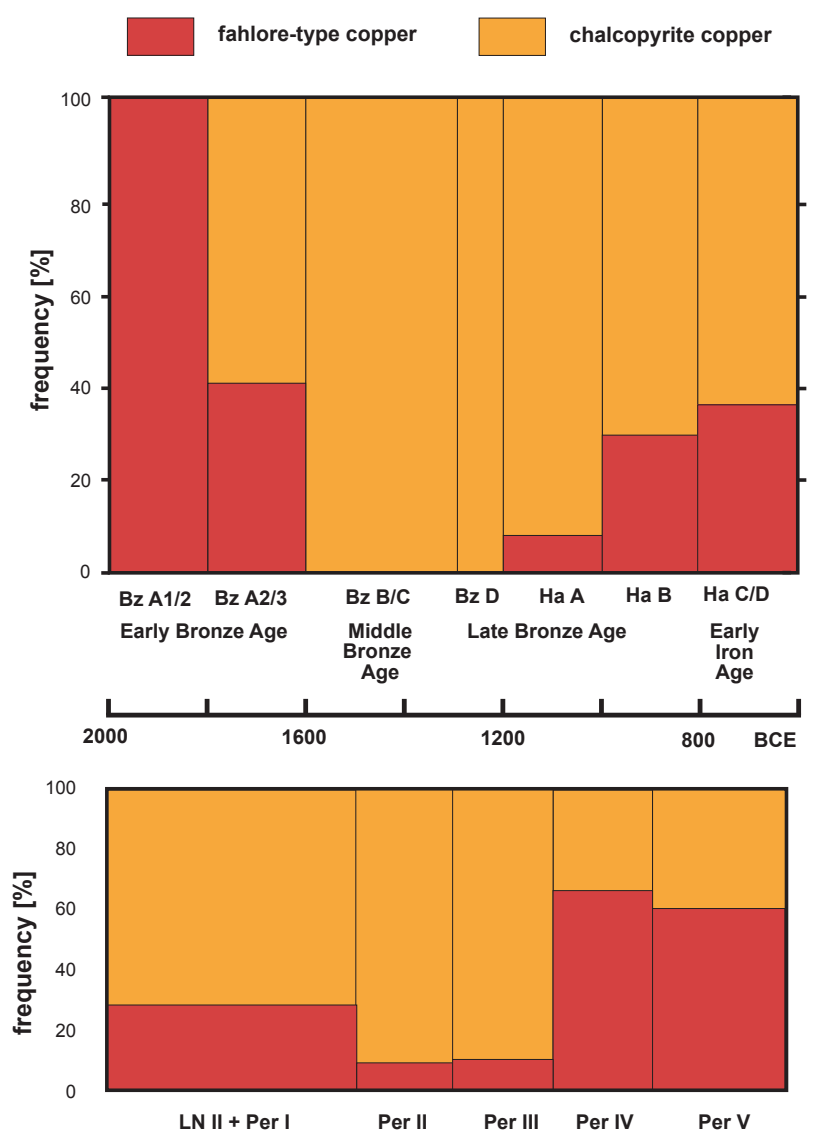

Fig. 20. - Top: Abundances of copper with fahlore and chalcopyrite signatures produced in the eastern Alps from the beginning of the Bronze Age into the Hallstatt period based on the compositions of some 1200 prehistoric metal artefacts from Tyrol, Salzburg and southern Bavaria. - Bottom: Abundances of copper with fahlore and chalcopyrite signatures in 70 metal artefacts from Sweden (LING et al. 2014) in roughly the same time range (CEZA, Mannheim).

in southern Sweden (Fig. 20). Therefore, one would expect that both metal types could have been supplied from this very active mining region in the Bronze Age. However, only two out of fifteen Swedish copper objects with a chemical signature that matches the Mitterberg ores and the Nebra hoard respectively match the Mitterberg lead isotope signature (Fig. 21).

Before accepting the Mediterranean provenance of the Swedish artefacts one should check archaeologically more reasonable possibilities like the Slovakian Ore Mountains that most likely were also exploited for copper in the central European Bronze Age, ${ }^{99}$ supplied the eastern parts of Austria, ${ }^{100}$ and certainly also the Carpathian Basin with copper. ${ }^{101}$ Furthermore, there are typological links between

99 Recently Garner et al. 2014.

100 Duberow, Pernicka, Krenn-Leeb 2009.

101 Pernicka et al. 2016. 


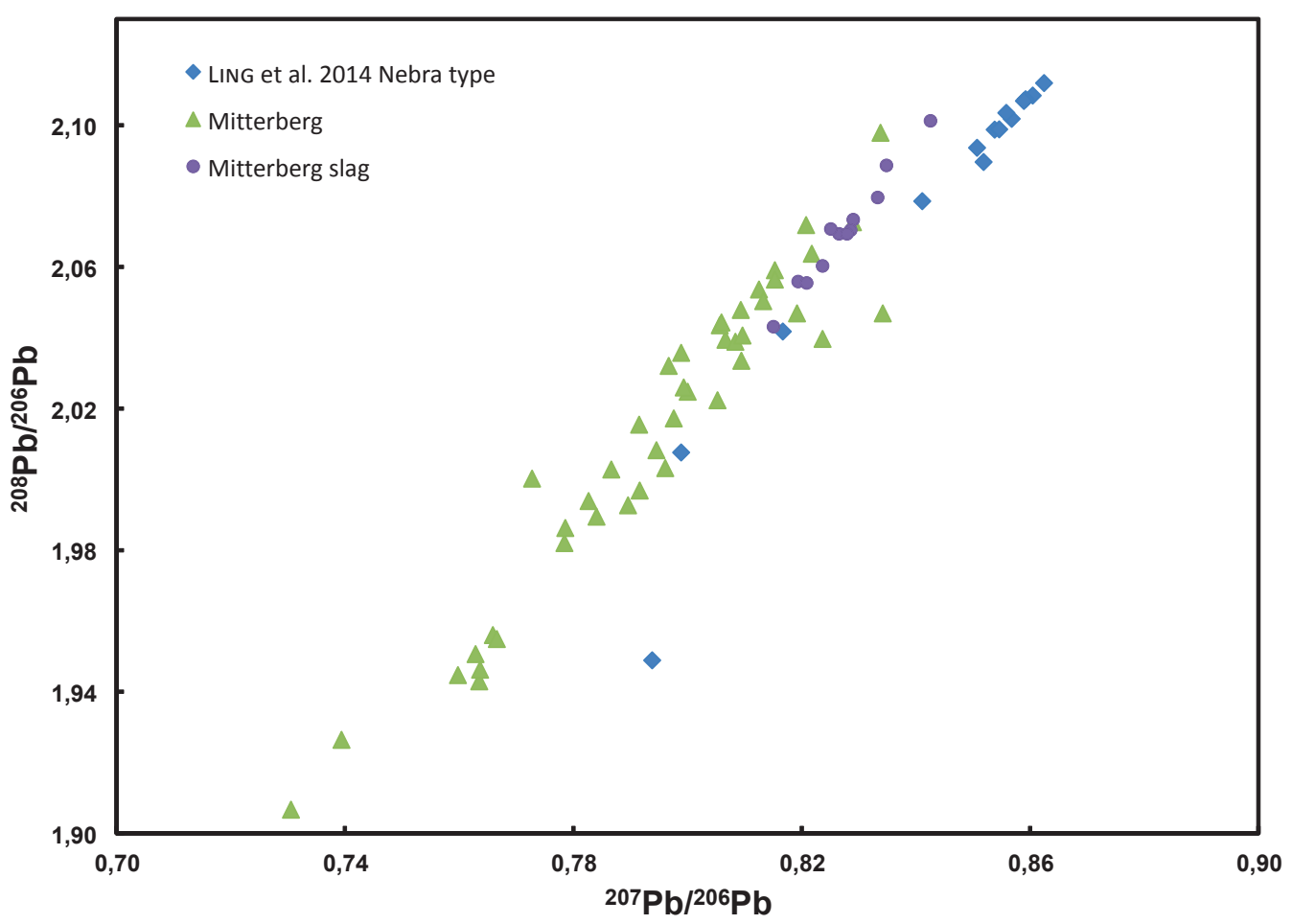

Fig.21. Lead isotope ratios of Swedish copper objects (Ling et al. 2014) with a chemical signature that matches the Mitterberg ores and the Nebra hoard compared with copper ores from the Mitterberg region (CEZA, Mannheim).

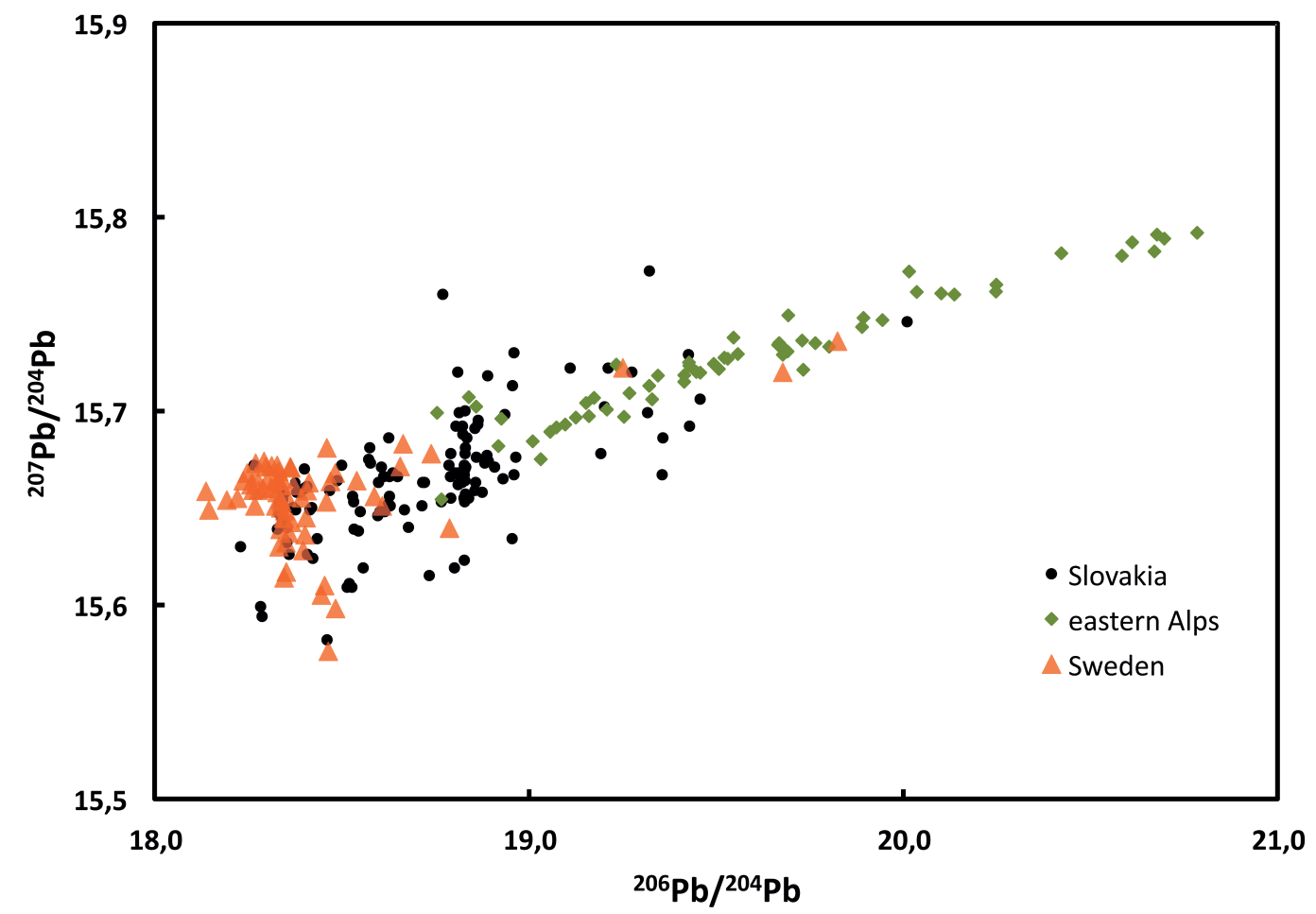

Fig. 22. Alternative lead isotope diagram to compare the ratios of prehistoric metal objects from southern Sweden (LiNG et al. 2014) with copper ores from the Mitterberg region and from the Hron Valley in southern Slovakia (Schreiner 2007) (CEZA, Mannheim). 


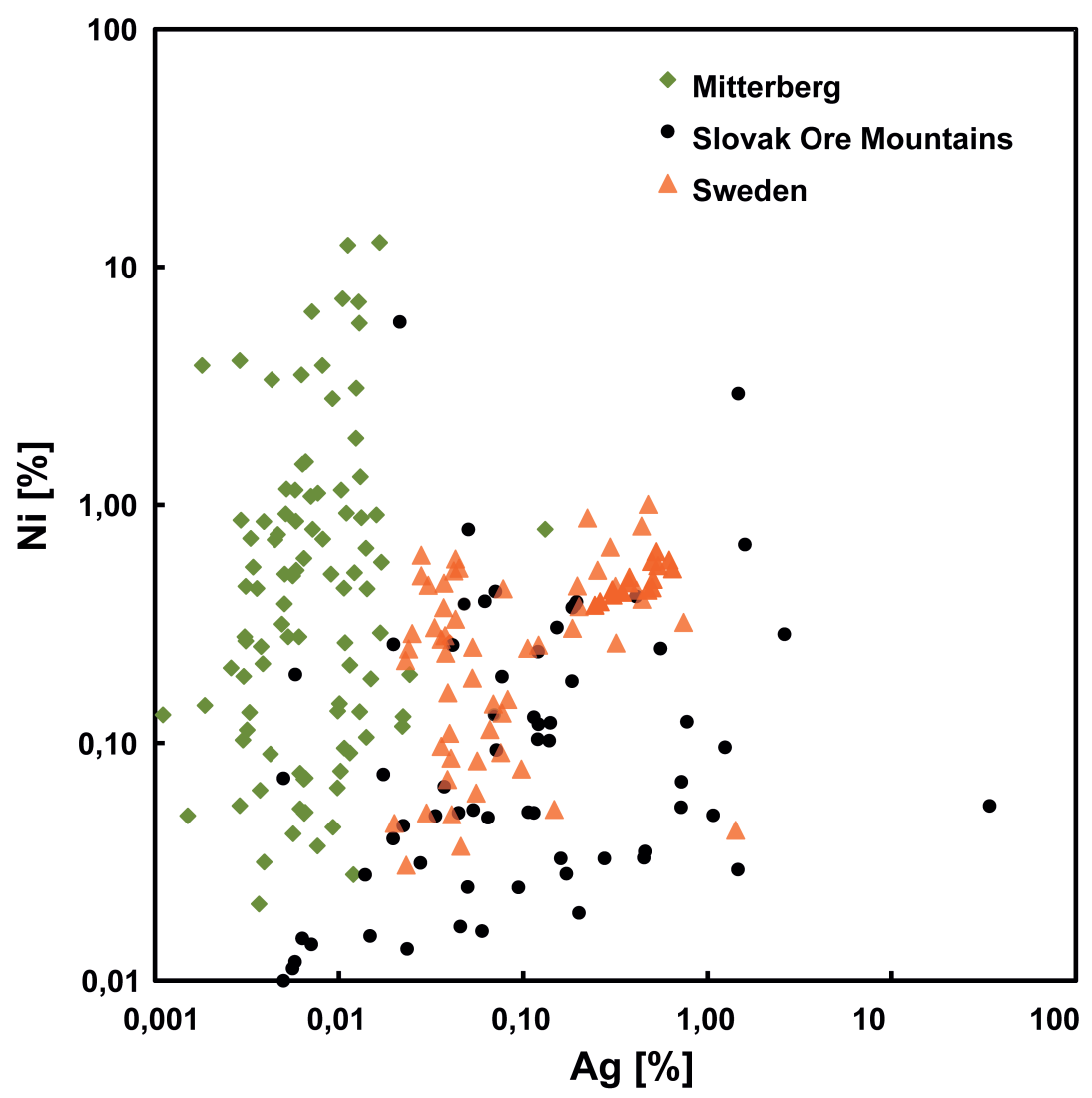

Fig. 23. Concentrations of silver and nickel in prehistoric metal objects from southern Sweden (Ling et al. 2014) compared with copper ores from the Mitterberg region and from the Hron valley in southern Slovakia (SCHREINER 2007). The concentration of the ore samples was recalculated assuming that the siderophile and chalcophile elements including copper add up to $100 \%$. Only ore samples with more than $10 \%$ copper were considered (CEZA, Mannheim).

the Carpathian basin and southern Sweden as exemplified by the Apa-type swords ${ }^{102}$ and the enigmatic objects of Balkåkra and Haschendorf/Hasfalva. ${ }^{103}$ In Figure 22 all lead isotope ratios of Ling et al. ${ }^{104}$ are plotted together with copper ores from the Mitterberg region and from the Hron Valley in southern Slovakia. ${ }^{105}$ The latter are much less radiogenic than the Mitterberg ores and largely overlap with the Swedish metal objects. The chemical composition of the Slovakian copper ores also matches the bulk of the objects (Fig. 23) so that there is no need to postulate a Mediterranean provenance for Bronze Age copper in southern Sweden. In this context it is worthwhile to note that fahlores also occur in the Slovakian Ore Mountains.

We may now conclude that low-impurity copper and copper with a fahlore signature reached southern Scandi-

102 Meller 2010.

103 Pernicka 2010.

104 LING et al. 2014.

105 SCHREINER 2007. navia in periods I and II according to the Nordic chronology, whereby copper from Slovakia seems to predominate. However, the number of analyses is probably too small to draw final conclusions. For the later periods, especially the central European Late Bronze Age coinciding with period III, the situation is substantially complicated by the observation that copper from various sources was apparently mixed. This has long been assumed by the appearance of hoards of broken tools, implements, and fragments of ingots that are commonly interpreted as scrap metal.

\section{Conclusion (T. Stöllner, E. Pernicka, J. Lutz)}

According to the data now available for the 'Mitterberg' mining region, there is no doubt that this region was a major producer of copper in Europe during the $18^{\text {th }}$ and $8^{\text {th }}$ centuries BC. Although the importance of Mitterberg was certainly recognised very early on, for a long time there was no possibility to discuss the distribution of this copper in more detail. Better understanding became possible thanks to 
extensive analytical programmes on the trace element patterns of Bronze Age metal objects ${ }^{106}$ that identified a chemically distinct 'east Alpine copper' that seemed to derive from chalcopyrite deposits in the Greywacke Zone. But it was not possible to differentiate between various mining sectors. This was, however, necessary to unfold the social dynamics behind the mining, trading and consumption practices resulting in a new quality of discussion. For the first time it is now possible to separate the different east Alpine mining districts according to their lead isotope and trace element characteristics in more detail, particularly those producing copper from chalcopyrite deposits. In comparison with the chemically more distinct fahlore deposits, such copper is more difficult to identify in prehistoric artefacts. Although this achievement still does not exclude other chalcopyrite deposits (Slovakian Ore Mountains, Mediterranean deposits) in general, good arguments can be found to securely identify the Mitterberg deposit copper either in artefacts from central Germany (e.g. the Nebra hoard), from the Alps (e.g. the Piller hoard ${ }^{107}$ but also from the Carpathian basin like the Apa and the Hajdúsámson hoards. ${ }^{108} \mathrm{It}$ is noteworthy that apart from the east Alpine deposits, the Slovakian Ore Mountains also come into consideration as a source of copper to the Nordic Bronze Age and to Sweden respectively. This has long been suspected by typological studies that seem to suggest a link between the Carpathian basin and southern Scandinavia in the Bronze Age. Therefore, it is not necessary to claim that there was an influx of Mediterranean copper to southern Scandinavia in the Bronze Age. Indeed, most of the published analyses of Scandinavian copper and bronze objects can be attributed to a source from central Europe.

Concerning the amount of copper produced at Mitterberg, especially between the $16^{\text {th }}$ and $12^{\text {th }}$ centuries BC, it is not surprising that this mining region dominated the metal exchange of so-called east Alpine copper during the Middle and Early Late Bronze Age, the period of the peak production. It is most likely that the largest part of the estimated overall production was achieved during this time (Fig. 6). Although we still have only a very rough idea about the quantities that were consumed in the key market regions, such as southern Germany and the Middle Danube area, central and northern Germany, and the Carpathian basin, it is obvious that the Mitterberg mines alone could not meet demand in later periods. It is known that the early phases

106 Pittioni 1957. - Pittioni 1959. - Junghans, SAngmeister, Schröder 1968a, b, c. - Junghans, SANGmeister, Schröder 1974. 107 See above and other regional examples such as the hoard from Pass Lueg (Lutz 2011). - See also STÖLLnER et al. 2016. 108 Pernicka 2013. - Pernicka et al. 2016. of the Late Bronze Age saw the rise of many production regions that mined and processed chalcopyrite and also the fahlores for copper, ${ }^{109}$ while the Mitterberg mining region began to decline, which as yet cannot be fully explained. As the ${ }^{14} \mathrm{C}$ dates and their correlation with the vegetation history indicates, ${ }^{110}$ it was probably a slow process with ups and downs even with the opening of new mining fields (Mitterberg eastern lodes) during the Urnfield period ${ }^{111}$ and the Early Iron Age. It is, however, difficult to trace the Mitterberg copper during this period because of the seemingly regular practice of metal mixing that dominated metal production in the eastern Alps. ${ }^{12}$

\section{Acknowledgements}

We would like to thank Michael Brauns, Bernd Höppner and Thorsten Schifer (all Curt-Engelhorn-Zentrum Archäometrie, Mannheim) for carrying out isotope and neutron activation analyses. We are also indebted to Gerhard Tomedi (Universität Innsbruck, Institut für Archäologien) and Walter Stephan (Museum Fliess) for access to prehistoric copper and bronze objects and to Robert Pils (Verein Montandenkmal Arthurstollen, Bischofshofen) and Franz Vavtar (Universität Innsbruck, Institut für Mineralogie und Petrographie) for supporting the field survey and sampling of ores. Mapping and statistical evaluation was supported by Annette Hornschuch and Jona Schröder (DBM); insight into new dendrodates was provided by K. Nicolussi, University of Innsbruck. This project was funded by the Austrian Science Fund (FWF, SFB F 31) and by the Deutsche Forschungsgemeinschaft (DFG).

\section{References}

Artioli et al. 2015

G. Artioli, I. Angelini, U. Tecchiati, A. Pedrotti, Eneolithic copper smelting slags in the eastern Alps: local patterns of metallurgical exploitation in the Copper Age, Journal of Archaeological Science 63, 2015, 78-83.

BATH-BílKová 1973

B. BATH-BílkovÁ, K problému původu hřiven-Zur Herkunftsfrage der Halsringbarren, Památky archeologické 64, 1973, 24-41.

BERNHARD 1965

J. Bernhard, Die Mitterberger Kupferkieslagerstätte: Erzführung und Tektonik, Jahrbuch der Geologischen Bundesanstalt 109, 1965, 3-90.

Berger, Schwab, Wunderlich 2010

D. Berger, R. Schwab, C.-H. Wunderlich, Technologische Untersuchungen zu bronzezeitlichen Metallziertechniken nördlich der Alpen vor dem Hintergrund des Hortfundes von Nebra. In: H. Meller, F. Bertemes (Eds.), Der Griff nach den Sternen: Wie Europas Eliten zu Macht und Reichtum kamen. Internationales Symposium in Halle (Saale) 16.-21. Februar 2005. Tagungen des Landesmuseums für Vorgeschichte 5/2, Halle (Saale) 2010, 751-778.

109 STÖLLNER 2009.

110 BREITENLECHNER et al. 2014.

111 Gstrein, Lippert 1988.

112 See above. - Also recently STÖLLNER et al. 2016. 
BONI, KÖPPEL 1985

M. BonI, V. KöppeL, Ore-lead isotope pattern from the Iglesiente-Sulcis Area (SW Sardinia) and the problem of remobilization of metals, 1985, 185-193.

BrAY et al. 2015

P. Bray, A. Cuenod, C. Gosden, P. Hommel, R. Liu, A.-M. PolLARD, Form and flow: the 'karmic cycle' of copper, Journal of Archaeological Science 56, 2015, 202-209.

BREITENLECHNER et al. 2014

E. Breitenlechner, T. StÖllner, P. Thomas, J. Lutz, K. Oeggl, An disciplinary study on the environmental reflection of prehistoric mining activities at the Mitterberg Main Lode (Salzburg, Austria), Archaeometry 56/1, 2014, 102-128.

CATtin et al. 2011

F. Cattin, B. Guénette-Beck, P. Curdy, N. Meisser, S. Ansermet, B. Hofmann, R. Kündig, V. Hubert, M. Wörle, K. Hametner, D. Günther, A. Wichser, A. Ulrich, I. M. Villa, M. Besse, Provenance of Early Bronze Age metal artefacts in western Switzerland using el-emental and lead isotopic compositions and their possible relation with copper minerals of the nearby Valais, Journal of Archaeological Science 38, 2011, 1221-1233.

Christoforidis, Pernicka, SCHickLer 1988

A. Christoforidis, E. Pernicka, H. Schickler, Ostalpine Kupferlagerstätten und ihre Bedeutung für die prähistorische Metallgewinnung in Mitteleuropa. Jahrbuch des Römisch-Germanischen Zentralmuseums Mainz 35, 1988, 533-536.

Clasen 1974

D. Clasen, Prätektonisches Sulfiderz aus dem Pinzgauer Phyllit westlich Mitterberg (Salzburg), Geologische Rundschau, 63, 1974, 124-135.

Duberow, Pernicka, Krenn-Leeb 2009

E. Duberow, E. Pernicka, A. Krenn-Leeb, Eastern Alps or western Carpathians: Early Bronze Age metal within the Wieselburg Culture. In: T. L. Kienlin, B. W. Roberts (Eds.), Metals and Societies. Studies in Honour of Barbara S. Ottaway. Universitätsforschungen zur prähistorischen Archäologie 169, Bonn 2009, 336-349.

Eibner-Persy, Eibner 1970

A. Eibner-Persy, C. Eibner, Erste Großgrabung auf dem bronzezeitlichen Bergbaugelände von Mitterberg, Der Anschnitt 22, $1970,12-19$.

EIBNER 1972

C. Eibner, Mitterberg-Grabung 1971, Der Anschnitt 24, 1972, 3-15. EIBNER 1973

C. Eibner, Mitterberg-Grabung 1972, Der Anschnitt 26, 1973, 14-22. EIBNER 1982

C. EIBNER, Kupfererzbergbau in Österreichs Alpen. In: B. HÄNSEL (Ed.), Südosteuropa zwischen 1600 und 1000 v. Chr. Prähistorische Archäologie in Südosteuropa 1, Berlin 1982, 399-408.

EIBNER 1994

C. EIbner, Die Pongauer Siedlungskammer und der Kupferbergbau in der Urzeit. In: W. Günther, C. Eibner, A. Lippert, W. PAar, 5000 Jahre Kupferbergbau Mühlbach am Hochkönig - Bischofshofen. Mühlbach am Hochkönig 1994, 11-26.

EIBNER 2016

C. Eibner, Ost und West, West und Ost, Mobilität und Technologietransfer. In: M. Bartelheim, B. Horejs, R. Krauss (Eds.), Von Baden bis Troia: Ressourcennutzung, Metallurgie und Wissenstransfer. Oriental and European Archaeology 3, Rahden/Westf. 2016, 439-451.
FAURe, Mensing 2005

G. Faure, T. M. Mensing, Isotopes: Principles and Applications (3 $3^{\text {rd }}$ edition). Hoboken NJ, 2005.

FROTZSCHER 2009

M. Frotzscher, Geochemische Charakterisierung von mitteleuropäischen Kupfervorkommen zur Herkunftsbestimmung des Kupfers der Himmelsscheibe von Nebra. PhD Dissertation, Martin-Luther-Universität Halle-Wittenberg 2009.

GARNER et al. 2014

J. Garner, M. Cheben, D. Demant, U. Enke, R. Herd, J. Labuda, D. Modarressi-Tehrani, T. Stöllner, P. Tóth, Neue montanarchäologische Untersuchungen im Slowakischen Erzgebirge, Der Anschnitt 66/2-3, 2014, 66-77.

Goldenkerg 2004

G. Goldenberg, Ein Verhüttungsplatz der mittleren Bronzezeit bei Jochberg (Nordtirol). In: G. Weisgerber, G. GoldenberG (Eds.), Alpenkupfer - Rame delle Alpi, Der Anschnitt Beiheft 17. Veröffentlichungen aus dem Deutschen Bergbau-Museum 122, Bochum 2004, 165-176.

GolDENBERg et al. 2012

G. Goldenberg, U. Töchterle, K. Oeggl, A. Krenn-Leeb (Eds.), Forschungsprogramm HiMAT - Neues zur Bergbaugeschichte der Ostalpen. Archäologie Österreichs Spezial 4, Vienna 2012.

GSTREIN 1988

P. Gstrein, Geologie, Mineralogie und Bergbau des Gebietes um Brixlegg. In: Marktgemeinde BrixlegG (Ed.), Brixlegg, eine Tiroler Gemeinde im Wandel der Zeiten. Brixlegg 1988, 11-62.

Gstrein 1989

P. Gstrein, Die Silberkammern von Schwaz, Tirol, Emser Hefte 10/3, 1989, 1-56.

Gstrein, LipPert 1988

P. Gstrein, A. Lippert, Untersuchungen bronzezeitlicher Pingen am Hochmoos bei Bischofshofen, Salzburg, Archaeologia Austriaca 71/1987, 1988, 89-100.

HANNING et al. 2013

E. Hanning, T. StÖllner, A. Hornschuch, B. Sikorski, Quantifying Bronze Age smelting sites in the Mitterberg mining district. In: P. Anreiter, K. Brandstätter, G. Goldenberg, K. Hanke, W. Leitner, K. Nicolussi, K. Oeggl, E. Pernicka, V. Schaffer, T. Stöllner, G. Tomedi, P. Tropper (Eds.), Mining in European History and its Impact on Environment and Human Societies - Proceedings for the $2^{\text {nd }}$ Mining in European History Conference of the FZ HiMAT, 7.-10. November 2012. Conference Series, Innsbruck 2013, 67-72.

HauptMann et al. 1992

A. Hauptmann, F. Beggemann. E. Heitkemper, E. Pernicka, S. Schmitt-STRecker, Early copper produced at Feinan, Wadi Araba, Jordan: the composition of ores and copper, Archaeomaterials $6 / 1,1992,1-33$.

Hauptmann, A. 2007

A. Hauptmann, The early metallurgy of copper: evidence from Faynan, Jordan. In: G. A. Wagner, B. Herrmann (Eds.), Natural Science in Archaeology. Heidelberg - Berlin-New-York 2007.

HÖPPNER et al. 2005

B. Höppner, M. Bartelheim, M. Huijsmans, R.Krauss, K.-P. Martinek, E. Pernicka, R. Schwab, Prehistoric copper production in the Inn Valley (Austria), and the earlierst copper in central Europe, Archaeometry 47, 2005, 295-318. 
Junghans, SANGMEISTER, SCHRÖDER 1960

S. Junghans, E. SAngmeister, M. Schröder, Metallanalysen kupferzeitlicher und frühbronzezeitlicher Bodenfunde aus Europa. Studien zu den Anfängen der Metallurgie 1, Berlin 1960.

Junghans, SANgmeister, Schröder 1968a

S. Junghans, E. Sangmeister, M. Schröder, Kupfer und Bronze in der frühen Metallzeit Europas: Die Metallgruppen beim Stand von 12000 Analysen. Studien zu den Anfängen der Metallurgie 2/1, Berlin 1968.

Junghans, SANGMEISTER, SCHrÖDER 1968 b

S. Junghans, E. Sangmeister, M. Schröder, Kupfer und Bronze in der frühen Metallzeit Europas: Tafeln, Tabellen, Diagramme, Karten. Studien zu den Anfängen der Metallurgie 2/2, Berlin 1968.

Junghans, SANGMEISTER, SCHRÖDER 1968c

S. Junghans, E. Sangmeister, M. Schröder, Kupfer und Bronze in der frühen Metallzeit Europas: Katalog der Analysen Nr. 985-10 040. Studien zu den Anfängen der Metallurgie 2/3, Berlin 1968.

JUNGHANS, SANGMEISTER, SCHRÖDER 1974

S. Junghans, E. Sangmeister, M. Schröder, Kupfer und Bronze in der frühen Metallzeit Europas: Katalog der Analysen Nr. $10041-$ 22000 (mit Nachuntersuchungen der Analysen Nr. 1-10 040). Studien zu den Anfängen der Metallurgie 2/4, Berlin 1974.

Klassen, Pernicka 1998

L. Klassen, E., Pernicka, Eine kreuzschneidige Axthacke aus Südskandinavien: Ein Beispiel für die Anwendungsmöglichkeiten der Stuttgarter Datenbank, Archäologisches Korrespondenzblatt 28, 35-45.

KLOSE 1918

O. Klose, Die prähistorischen Funde vom Mitterberge bei Bischofshofen im städtischen Museum Carolino-Augusteum zu Salzburg und zwei prähistorische Schmelzöfen auf dem Mitterberge. (Erschienen Oktober 1916). In: G. KyrLE, Österreichische Kunsttopographie 17: Urgeschichte des Kronlandes Salzburg. Wien 1918, Beitrag II/Prähistorische Funde und Schmelzöfen von Mitterberg, 1-40.

Koch-Waldner, Klaunzer 2015

T. Koch-Waldner, M. Klaunzer, Das prähistorische Bergbaugebiet in der Region Kitzbühel. In: T. STÖllner, K. OEgGL (Eds.), Bergauf Bergab: 10.000 Jahre Bergbau in den Ostalpen. Wissenschaftlicher Beiband zur Ausstellung im Deutschen BergbauMuseum Bochum vom 31.10.2015 - 24.04.2016. Im Vorarlberg Museum Bregenz vom 11.06.2016 - 26.10.2016. Veröffentlichungen des Deutschen Bergbau-Museums 207, Rahden/Westf. 2015, 165-173.

KRISTIANSEN 1998

K. Kristiansen, Europe before History. Cambridge 1998.

KYRLE 1918

G. Kyrle, Der prähistorische Bergbaubetrieb in den Salzburger Alpen. (Abgeschlossen Ende 1913, erschienen Oktober 1916). In: G. KyrLe, Österreichische Kunsttopographie 17: Urgeschichte des Kronlandes Salzburg. Wien 1918, Beitrag I/Bergbaubetrieb in den Salzburger Alpen, 1-70.

LiNG et al. 2013

J. Ling, E. Hjärthner-Holdar, L. Grandin, K. Billström, P.-O. Persson, Moving metals or indigenous mining? Provenancing Scandinavian Bronze Age artefacts by lead isotopes and trace elements, Journal of Archaeological Science 40, 2013, 291-304.
LiNG et al. 2014

J. Ling, Z. Stos-Gale, L. Grandin, K. Billström, E. HJärthner-Holdar, P.-O. Persson, Moving metals II: provenancing Scandinavian Bronze Age artefacts by lead isotope and elemental analyses, Journal of Archaeological Science 41, 2014, 106-132.

LIPPERT 1992

A. LIPPERT, Der Götschenberg bei Bischofshofen: Eine ur- und frühgeschichtliche Höhensiedlung im Salzachpongau. Mitteilungen der prähistorischen Kommission 27, Wien 1992.

LiPPERT, STADLER 2009

A. Lippert, P. Stadler, Das spätbronze- und früheisenzeitliche Gräberfeld von Bischofshofen-Pestfriedhof. Universitätsforschungen zur Prähistorischen Archäologie 168, Bonn 2009.

LUTz 2011

J. LuTz, Materialanalytische Untersuchungen an den Helmen vom Pass Lueg, Anlauftal und Moosbruckschrofen. In: A. LIPPERT (Ed.), Die zweischaligen ostalpinen Kammhelme und verwandte Helmformen der späten Bronze- und frühen Eisenzeit. Archäologie in Salzburg 6, Salzburg 2011, 113-117.

LuTz 2016

J. Lutz, Alpenkupfer: Die Ostalpen als Rohstoffquelle in vorgeschichtlicher Zeit. In: M. Bartelheim, B. Horejs, R. Krauss (Eds.), Von Baden bis Troia: Ressourcennutzung, Metallurgie und Wissenstransfer. Oriental and European Archaeology 3, Rahden/Westf. 2016, 333-358.

LuTz et al. 2010

J. Lutz, E. Pernicka, R. Pils, G. Tomedi, F. Vavtar, Geochemical characteristics of copper ores from the Greywacke Zone in the Austrian Alps and their relevance as a source of copper in prehistoric times. In: P. Anreiter, G. Goldenberg, K. Hanke, R. Krause, W. Leitner, F. Mathis, K. Nicolussi, K. Oeggl, E. Pernicka, M. Prast, J. Schibler, I. Schneider, H. Stadler, T. Stöllner, G. Tomedi, P. Tropper (Eds.), Mining in European History and its Impact on Environment and Human Societies - Proceedings for the $1^{\text {st }}$ Mining in European History-Conference of the SFB-HiMAT, 12.-15. November 2009, Innsbruck. Conference Series, Innsbruck 2010, 145-150.

MARTINEK 1996

K.-P. Martinek, Archäometallurgische Untersuchungen zur frühbronzezeitlichen Kupferproduktion und -verarbeitung auf dem Buchberg bei Wiesing, Tirol. Fundberichte aus Österreich 34/1995, 1996, 575-584.

Meller 2010

H. Meller, Nebra: Vom Logos zum Mythos - Biographie eines Himmelsbildes. . In: H. Meller, F. Bertemes (Eds.), Der Griff nach den Sternen: Wie Europas Eliten zu Macht und Reichtum kamen. Internationales Symposium in Halle (Saale) 16.-21. Februar 2005. Tagungen des Landesmuseums für Vorgeschichte 5/1, Halle (Saale) 2010, 23-73.

Menke 1982

M. Menke, Studien zu den Frühbronzezeitlichen Metalldepots Bayerns. Jahresbericht der Bayerischen Bodendenkmalpflege 19-20/1978-1979, Bonn 1982.

Much 1878

M. Much, Das vorgeschichtliche Kupferbergwerk auf dem Mitterberg (Salzburg). I., Mittheilungen der K. K. Central-Commission zur Erforschung und Erhaltung der Kunst- und historischen Denkmale N. F. 4, 1878, 146-152. 
Much 1879

M. Much, Das vorgeschichtliche Kupferbergwerk auf dem Mitterberg (Salzburg). (Schluß), Mittheilungen der K. K. CentralCommission zur Erforschung und Erhaltung der Kunst- und historischen Denkmale N. F. 5, 1879, 18-36.

Nicolussi, Pichler, Thurner 2015

K. Nicolussi, T. Pichler, A. Thurner, Dendro-Daten zum prähistorischen Kupferbergbau in Westösterreich. In: T. STÖLLNER, K. OegGL (Eds.), Bergauf Bergab: 10.000 Jahre Bergbau in den Ostalpen. Wissenschaftlicher Beiband zur Ausstellung im Deutschen Bergbau-Museum Bochum vom 31.10.2015 - 24.04.2016. Im Vorarlberg Museum Bregenz vom 11.06.2016 - 26.10.2016. Veröffentlichungen des Deutschen Bergbau-Museums 207, Rahden/Westf. 2015, 239-246.

Niederschlag et al. 2003

E. Niederschlag, E. Pernicka, T. Seifert, M. Bartelheim, Determination of lead isotope ratios by Multiple Collector ICPMS: a case study of Early Bronze Age artefacts and their possible relation with ore deposits of the Erzgebirge, Archaeometry 45, 2003, 61-100.

Northover 2009

P. NoRThover, Analysis and metallography of copper alloy metalwork. In: A. Lippert, P. STAdLer, Das spätbronze- und früheisenzeitliche Gräberfeld von Bischofshofen-Pestfriedhof. Universitätsforschungen zur Prähistorischen Archäologie 168, Bonn 2009, 351-384.

Neuninger, Pittioni 1962

H. Neuninger, R. Pittioni, Bemerkungen über zwei Methoden der spektralanalytischen Untersuchung urzeitlicher Kupfer- und Bronzeobjekte, Archaeologia Austriaca 31, 1962, 96-102.

Neuninger, Pittioni 1963

H. Neuninger, R. Pittioni, Frühmetallzeitlicher Kupferhandel im Alpenvorland: Zur Frage der Herkunft des Ringbarrenkupfers, Archaeologia Austriaca Beiheft 6. Archiv für ur- und frühgeschichtliche Bergbauforschung 22, Vienna 1963.

Oeggl et al. 2008

K. Oeggl, F. Mathis, J. Moser, I. Schneider, W. Leitner, G. Tomedi, T. Stöllner, R. Krause, E. Pernicka, P. Tropper, J. Schibler, K. Nicolussi, K. Hanke, The history of mining activities in the Tyrol and adjacent areas: impact on environment and human societies (HiMAT), Antiquity 82, 2008. Project gallery: http://www.antiquity.ac.uk/projgall/oeggl/ (last accessed 7.11.2016).

Pernicka 1984

E. Pernicka, Instrumentelle Multi-Elementanalyse archäologischer Kupfer- und Bronzeartefakte: Ein Methodenvergleich, Jahrbuch des Römisch-Germanischen Zentralmuseums Mainz 31, 1984, 517-531.

Pernicka 1990

E. Pernicka, Gewinnung und Verbreitung der Metalle in prähistorischer Zeit, Jahrbuch des Römisch-Germanischen Zentralmuseums Mainz 37, 1990, 21-129.

Pernicka 1999

E. Pernicka, Trace element fingerprinting of ancient copper: a guide to technology or provenance? In: S. M. M. Young, A. M. PoLLARD, P. Budd, R. A. Ixer (Eds.), Metals in Antiquity. BAR International Series 792, Oxford 1999, 163-171.
Pernicka 2010

E. Pernicka, Archäometallurgische Untersuchungen am und zum Hortfund von Nebra. In: H. Meller, F. Bertemes (Eds.), Der Griff nach den Sternen: Wie Europas Eliten zu Macht und Reichtum kamen. Internationales Symposium in Halle (Saale) 16.-21. Februar 2005. Tagungen des Landesmuseums für Vorgeschichte 5/2, Halle (Saale) 2010, 719-734.

Pernicka 2013

E. Pernicka, Analyses of Early Bronze Age metal objects from the Museum in Debrecen, Hungary, Gesta XII, 48-55.

Pernicka, Wunderlich 2002

E. Pernicka, C. H. Wunderlich, Naturwissenschaftliche Untersuchungen an den Funden von Nebra, Archäologie in SachsenAnhalt 1, 17-22.

Pernicka et al. 1993

E. Pernicka, F. Begemann, S. Schmitt-Strecker, G. A. Wagner, Eneolithic and Early Bronze Age artefacts from the Balkans and their relation to Serbian copper ores, Praehistorische Zeitschrift 68, 1993, 1-54.

Pernicka et al. 2008

E. Pernicka, C.-H. Wunderlich, A. Reichenberger, H. Meller, G. Borg, Zur Echtheit der Himmelsscheibe von Nebra - eine kurze Zusammenfassung der durchgeführten Untersuchungen, Archäologisches Korrespondenzblatt, 38, 2008, 331-352.

Pernicka et al. 2016

E. Pernicka, B. Nessel, M. Mehofer, E. Safta, Lead isotope analyses of metal objects from the Apa Hoard and other Early and Middle Bronze Age items from Romania, Archaeologia Austriaca 100, 2016, 57-86.

Perucchetti et al. 2015

L. Perucchetti, P. Bray, A. Dolfini, A. M. Pollard, Physical barriers, cultural connections: prehistoric metallurgy across the Alpine region, European Journal of Archaeology 18, 2015, 599-632.

Pittioni 1947

R. PitTioni, Untersuchungen im Bergbaugebiete Kelchalpe bei Kitzbühel, Tirol: Zweiter Bericht über die Arbeiten 1937/1938 zur Urgeschichte des Kupferbergwesens in Tirol. Mitteilungen der Prähistorischen Kommission der Akademie der Wissenschaften 5/2-3, Vienna 1947.

PitTioni 1957

R. Pittioni, Urzeitlicher Bergbau auf Kupfererz und Spurenanalyse: Beiträge zum Problem der Relation Lagerstätte-Fertigobjekt, Archaeologia Austriaca Beiheft 1. Archiv für ur- und frühgeschichtliche Bergbauforschung 10, Vienna 1957.

Pittioni 1959

R. Pittioni, Zweck und Ziel spektralanalytischer Untersuchungen für die Urgeschichte des Kupferbergwesens, Archaeologia Austriaca 26, 1959, 67-95.

Preuschen, Pittioni 1937

E. Preuschen, R. Pittioni, Untersuchungen im Bergbaugebiete Kelchalpe bei Kitzbühel, Tirol: Erster Bericht über die Arbeiten 1931-1936 zur Urgeschichte des Kupferbergwesens in Tirol. Mitteilungen der Prähistorischen Kommission der Akademie der Wissenschaften 3/1-3, Vienna 1937.

Preuschen, Pittioni 1954

E. Preuschen, R. Pittioni, Untersuchungen im Bergbaugebiet Kelchalm bei Kitzbühel, Tirol: Dritter Bericht über die Arbeiten 1946-1953 zur Urgeschichte des Kupferbergwesens in Tirol, Archaeologia Austriaca 15. Archiv für ur- und frühgeschichtliche Bergbauforschung 7, 1954, 3-97. 
RIESER, SCHRATTENTHALER 1998-1999

B. Rieser, H. Schrattenthaler, Urgeschichtlicher Kupferbergbau im Raum Schwaz-Brixlegg, Tirol, Archaeologia Austriaca 82-83, 1998-1999, 135-179.

SCHLOSSER 2003

W. Schlosser, Astronomische Deutung der Himmelsscheibe von Nebra, Sterne und Weltraum 12, 2003, 34-38.

SCHREINER 2007

M. Schreiner, Erzlagerstätten im Hrontal, Slowakei: Genese und prähistorische Nutzung. Forschungen zur Archäometrie und Altertumswissenschaft 3, Rahden/Westf. 2007.

Schubert, Pernicka 2013

M. Schubert, E. Pernicka, Die frühbronzezeitliche Kupferverarbeitung auf dem Buchberg im Unterinntal, Tirol. In: Montanwerke Brixlegg AG, K. Oeggly, V. Schaffer (Eds.), Cuprum Tyrolense: 5550 Jahre Bergbau und Kupferverhütung in Tirol. Brixlegg 2013, 123-152.

SHENNAN 1995

S. Shennan, Bronze Age Copper Producers of the Eastern Alps. Universitätsforschungen zur prähistorischen Archäologie 27, Bonn 1995.

SORMAZ, STÖLLNER 2009

T. Sormaz, T. STÖLlner, Der bronzezeitliche Bergbau im Südrevier des Mitterberggebietes: Bericht zu den Forschungen der Jahre 2002 bis 2006 - Dendrochronologie und Radiokarbonuntersuchungen: Die Datierung des bronzezeitlichen Bergwerkes im Arthurstollen, Archaeologia Austriaca 90/2006, 2009, 112-114.

SPERBER 2004

L. Sperber, Zur Bedeutung des nördlichen Alpenraumes für die spätbronzezeitliche Kupferversorgung in Mitteleuropa: Mit besonderer Berücksichtigung Nordtirols. In: G. WeIsGERBER, G. Goldenberg (Eds.), Alpenkupfer - Rame delle Alpi, Der Anschnitt Beiheft 17. Veröffentlichungen aus dem Deutschen Bergbau-Museum 122, Bochum 2004, 303-345.

SPINDLER 1971

K. Spindler, Zur Herstellung der Zinnbronze in der frühen Metallurgie Europas, Acta Praehistorica et Archaeologica 2, 1971, 199-253.

SPINDLER 2006

K. Spindler, Die beiden frühbronzezeitlichen Flügelnadeln aus dem Tempelschatz vom Piller bei Fließ im Tiroler Oberland, ArchaeoTirol Kleine Schriften 5, 2006, 43-64.

STÖLLNER 2003

T. STÖLlner, Mining and economy: a discussion of spatial organisations and structures of early raw material exploitation. In: T. Stöllner, G. Körlin, G. Steffens, J. Cierny (Eds.), Man and Mining: Studies in Honour of Gerd Weisgerber, Der Anschnitt Beiheft 16. Veröffentlichungen aus dem Deutschen Bergbau-Museum 114, Bochum 2003, 415-446.

STÖLLNER 2009

T. STÖllner, Prähistorische Montanreviere in den Ost- und Südalpen: Anmerkungen zu einem Forschungsstand. In: K. OEGGL, M. Prast (Eds.), Die Geschichte des Bergbaues in Tirol und seinen angrenzenden Gebieten. Proceedings zum 3. MilestoneMeeting des SFB HiMAT vom 23.-26.10.2008 in Silbertal. Conference Series, Innsbruck 2009, 37-60.

STÖLlnER 2011

T. STÖllner, Das Alpenkupfer der Bronze- und Eisenzeit: Neue Aspekte der Forschung. In: K. Sснмотz (Ed.), Vorträge des 29. Niederbayerischen Archäologentages. Rahden/Wetsf. 2011, 25-70.
STÖLLNER 2015

T. STÖLlner, Der Mitterberg als Großproduzent für Kupfer in der Bronzezeit. In: T. Stöllner, K. Oeggl (Eds.), Bergauf Bergab: 10.000 Jahre Bergbau in den Ostalpen. Wissenschaftlicher Beiband zur Ausstellung im Deutschen Bergbau-Museum Bochum vom 31.10.2015 - 24.04.2016. Im Vorarlberg Museum Bregenz vom 11.06.2016 - 26.10.2016. Veröffentlichungen des Deutschen Bergbau-Museums 207, Rahden/Westf. 2015, 175-185.

Stöllner, Eibner, Cierny 2004

T. Stöllner, C. Eibner, J. Cierny, Prähistorischer Kupferbergbau Arthurstollen: ein neues Projekt im Südrevier des MitterbergGebietes (Salzburg). In: G. Weisgerber, G. Goldenberg (Eds.), Alpenkupfer - Rame delle Alpi, Der Anschnitt Beiheft 17. Veröffentlichungen aus dem Deutschen Bergbau-Museum 122, Bochum 2004, 95-106.

StÖllner, Hanning, Hornschuch 2011

T. Stöllner, E. Hanning, A. Hornschuch, Ökonometrie des Kupferproduktionsprozesses am Mitterberger Hauptgang. In: K. Oeggl, G. Goldenberg, T. Stöllner, M. Prast (Eds.), Die Geschichte des Bergbaues in Tirol und seinen angrenzenden Gebieten. Proceedings zum 5. Milestone-Meeting des SFB HiMAT vom 07.-10.10.2010 in Mühlbach. Conference Series, Innsbruck 2011, 115-128.

StÖllner, OEgGl 2015

T. Stöllner, K. OegGl (Eds.), Bergauf Bergab: 10.000 Jahre Bergbau in den Ostalpen. Wissenschaftlicher Beiband zur Ausstellung im Deutschen Bergbau-Museum Bochum vom 31.10.2015 - 24.04.2016. Im Vorarlberg Museum Bregenz vom 11.06.2016 - 26.10.2016. Veröffentlichungen des Deutschen Bergbau-Museums 207, Rahden/Westf. 2015.

STÖLlNER, SCHWAB 2009

T. Stöllner, R. Schwab, Hart oder weich? Worauf es ankommt: Pickel aus dem prähistorischen Bergbau in den Ostalpen. Festschrift Fritz Eckart Barth zum 70. Geburtstag, Mitteilungen der Anthropologischen Gesellschaft in Wien 139, 2009, 149-166.

STÖLLNER et al. 2009

T. Stöllner, J. Cierny, C. Eibner, N. Boenke, R. Herd, A. MaAss, K. Röttger, T. Sormaz, G. Steffens, P. Thomas, Der bronzezeitliche Bergbau im Südrevier des Mitterberggebietes: Bericht zu den Forschungen der Jahre 2002 bis 2006, Archaeologia Austriaca 90/2006, 2009, 87-137.

STÖLLNER et al. 2012

T. Stöllner, E. Breitenlechner, C. Eibner, R. Herd, T. Kienlin, J. Lutz, A. Maass, K. Nicolussi, T. Pichler, R. Pils, K. RötTger, B. Song, N. Taube, P. Thomas, A. Thurner, Der Mitterberg - Der Großproduzent für Kupfer im östlichen Alpenraum der Bronzezeit. In: G. Goldenberg, U. Töchterle, K. Oeggl, A. Krenn-Leeb (Eds.), Forschungsprogramm HiMAT - Neues zur Bergbaugeschichte der Ostalpen. Archäologie Österreichs Spezial 4, Vienna 2012, 113-144.

STÖLLNER et al. 2016

T. Stöllner, C. von Rüden, E. Hanning, J. Lutz, S. Kluwe, E. Pernicka, The enmeshment of eastern Alpine mining communities in the Bronze Age: from economic networks to communities of practice. In: G. Körlin, M. Prange, T. STöllner, Ü. Yalcin (Eds.), From Bright Ores to Shiny Metals. Festschrift for Andreas Hauptmann on the Occasion of 40 Years Research in Archaeometallurgy and Archaeometry, Der Anschnitt Beiheft 29. Veröffentlichungen aus dem Deutschen Bergbau-Museum Bochum 210, Bochum 2016, 75-107. 
SYDOW 1995

W. Sydow, Der hallstattzeitliche Bronzehort von Fließ im Oberinntal. Fundberichte aus Österreich, Materialhefte A3, Horn 1995.

SyDOW 1996

W. Sydow, Eine frühbronzezeitliche Fundstelle am Buchberg, Gemeinde Wiesing (Tirol), Fundberichte aus Österreich 34/1995, 1996, 567-573.

Tomedi 2001

G. TomedI, Gedanken zur Interpretation des Schatzfundes vom Moosbruckschrofen am Piller, ArchaeoTirol Kleine Schriften 3, 2001, 76-90.

Tomedi 2002

G. Tomedi, Zur Datierung des Depotfundes vom Piller, ArchaeoTirol Kleine Schriften 4, 2002, 43-46.

Tomedi, Nicolussi Castellan, Pöll 2001

G. Tomedi, S. Nicolussi Castellan, J. Pöll, Die Bergung des Schatzfundes vom Mossbruckschrofen am Piller, Ge. Fliess, ArchaeoTirol Kleine Schriften 3, 2001, 37-52.

Weber, Pausweg, Medwenitsch 1972

L. Weber, F. Pausweg, W. Medwenitsch, Zur Mitterberger Kupfervererzung im Südrevier (Arthurstollen): ein Diskussionsbeitrag, Mitteilungen der Geologischen Gesellschaft in Wien 64/1971, 1972, 209-218.

Weber, Pausweg, Medwenitsch 1973

L. Weber, F. Pausweg, W. Medwenitsch, Zur Mitterberger Kupfervererzung (Mühlbach/Hochkönig): zweiter Diskussionsbeitrag, Mitteilungen der Geologischen Gesellschaft in Wien 65/1972, 1973, 137-158.

WEBER 1997

L. Weber (Ed.), Handbuch der Lagerstätten der Erze, Industrieminerale und Energierohstoffe Österreichs: Erläuterungen zur metallogenetischen Karte von Österreich 1:500 000 unter Einbeziehung der Industrieminerale und Energierohstoffe. Archiv für Lagerstättenforschung der Geologischen Bundesanstalt 19, Vienna 1997.

Zschocke, Preuschen 1932

K. Zschocke, E. Preuschen, Das urzeitliche Bergbaugebiet von Mühlbach-Bischofshofen. Materialien zur Urgeschichte Österreichs 6, Wien 1932.
Ernst Pernicka

Curt-Engelhorn-Zentrum Archäometrie

D6, 3

68159 Mannheim

Germany

ernst.pernicka@cez-archaeometrie.de

Institute of Earth Sciences

University of Heidelberg

Im Neuenheimer Feld 234-236

69120 Heidelberg

Germany

ernst.pernickageow.uni-beidelberg.de

Joachim Lutz

Curt-Engelhorn-Zentrum Archäometrie

D6, 3

68159 Mannbeim

Germany

joachim.lutz@cez-archaeometrie.de

Thomas Stöllner

Deutsches Bergbau-Museum

Herner Straße 45

44787 Bochum

Germany

thomas.stoellner@bergbaumuseum.de

Rubr-University Bochum

Institute of Archaeological Studies

Pre-and Protohistory

Am Bergbaumuseum 31

44791 Bochum

thomas.stoellner@rub.de 
Tab. 3. Sampling sites and laboratory numbers.

\begin{tabular}{|c|c|c|c|c|}
\hline Lab no. & Field label & Location & $\mathbf{N}$ & $\mathrm{E}$ \\
\hline MA-080582 & Mitterberg 07-1 & main lode, Annastollen & - & - \\
\hline MA-080583 & Mitterberg 07-2 & Brander lode, Arthurstollen, Nordgang (compressor room) & - & - \\
\hline MA-080584 & MS 1 & Brander lode & - & - \\
\hline MA-080585 & MS 4d & Brander lode & - & - \\
\hline MA-080586 & MS 6b & Brander lode & - & - \\
\hline MA-080587 & MS 7 & Brander lode & - & - \\
\hline MA-080588 & MS $8 b$ & Brander lode & - & - \\
\hline MA-080589 & MS 9 & Brander lode & - & - \\
\hline MA-081367 & MB 12-1 & Birkstein lode, Halde Josef-/Ederstollen & $47^{\circ} 21.877^{\prime}$ & $13^{\circ} 11.249^{\prime}$ \\
\hline MA-081368 & MB 12-2 & Birkstein lode, Halde Josef-/Ederstollen & $47^{\circ} 21.877^{\prime}$ & $13^{\circ} 11.249^{\prime}$ \\
\hline MA-081369 & MB 12-3 & Birkstein lode, Halde Josef-/Ederstollen & $47^{\circ} 21.877^{\prime}$ & $13^{\circ} 11.249^{\prime}$ \\
\hline MA-081370 & MB 12-4 & Birkstein lode, Halde Josef-/Ederstollen & $47^{\circ} 21.877^{\prime}$ & $13^{\circ} 11.249^{\prime}$ \\
\hline MA-081371 & MB 12-5 & Birkstein lode, Halde Josef-/Ederstollen & $47^{\circ} 21.877^{\prime}$ & $13^{\circ} 11.249^{\prime}$ \\
\hline MA-081372 & MB 12-6 & Birkstein lode, Halde Josef-/Ederstollen & $47^{\circ} 21.877^{\prime}$ & $13^{\circ} 11.249^{\prime}$ \\
\hline MA-081373 & MB 12-7 & Birkstein lode, Halde Josef-/Ederstollen & $47^{\circ} 21.877^{\prime}$ & $13^{\circ} 11.249^{\prime}$ \\
\hline MA-081374 & MB 12-8 & Birkstein lode, Halde Josef-/Ederstollen & $47^{\circ} 21.877^{\prime}$ & $13^{\circ} 11.249^{\prime}$ \\
\hline MA-081375 & MB 12-9 & Birkstein lode, Halde Josef-/Ederstollen & $47^{\circ} 21.877^{\prime}$ & $13^{\circ} 11.249^{\prime}$ \\
\hline MA-081376 & MB 12-10 & Birkstein lode, Halde Josef-/Ederstollen & $47^{\circ} 21.877^{\prime}$ & $13^{\circ} 11.249^{\prime}$ \\
\hline MA-081377 & MB 13 & Brander lode, Arthurstollen, Südgang (Stollenmeter 502) & - & - \\
\hline MA-081378 & MB 14 & Brander lode, Arthurstollen, Nordgang (Stollenmeter 490) & - & - \\
\hline MA-081379 & MB 15 & Brander lode, Arthurstollen, Nordgang (Stollenmeter 946) & - & - \\
\hline MA-081380 & MB 16 & Brander lode, Arthurstollen, Nordgang (compressor room) & - & - \\
\hline MA-081381 & MB 17-1 & Brander lode, Arthurstollen, Nordgang (Tiefbau) & - & - \\
\hline MA-081382 & MB 17-2 & Brander lode, Arthurstollen, Nordgang (Tiefbau) & - & - \\
\hline MA-081383 & MB 23 & Brander lode, Höchstollen & - & - \\
\hline MA-081384 & MB 24 & Brander lode, Arthurstollen & - & - \\
\hline MA-081385 & MB 1-1 & main lode, mining dump Annastollen & $47^{\circ} 24.546^{\prime}$ & $13^{\circ} 08.666^{\prime}$ \\
\hline MA-081386 & MB 1-2 & main lode, mining dump Annastollen & $47^{\circ} 24.546^{\prime}$ & $13^{\circ} 08.666^{\prime}$ \\
\hline MA-081387 & MB 1-3 & main lode, mining dump Annastollen & $47^{\circ} 24.546^{\prime}$ & $13^{\circ} 08.666^{\prime}$ \\
\hline MA-081388 & MB 1-4 & main lode, mining dump Annastollen & $47^{\circ} 24.546^{\prime}$ & $13^{\circ} 08.666^{\prime}$ \\
\hline MA-081389 & MB 1-5 & main lode, mining dump Annastollen & $47^{\circ} 24.546^{\prime}$ & $13^{\circ} 08.666^{\prime}$ \\
\hline MA-081390 & MB 1-6 & main lode, mining dump Annastollen & $47^{\circ} 24.546^{\prime}$ & $13^{\circ} 08.666^{\prime}$ \\
\hline MA-081391 & MB 1-7 & main lode, mining dump Annastollen & $47^{\circ} 24.546^{\prime}$ & $13^{\circ} 08.666^{\prime}$ \\
\hline MA-081392 & MB 1-8 & main lode, mining dump Annastollen & $47^{\circ} 24.546^{\prime}$ & $13^{\circ} 08.666^{\prime}$ \\
\hline MA-081393 & MB 2-1 & main lode, mining dump Danielstollen & $47^{\circ} 24.696^{\prime}$ & $13^{\circ} 09.009^{\prime}$ \\
\hline MA-081394 & MB 2-2 & main lode, mining dump Danielstollen & $47^{\circ} 24.696^{\prime}$ & $13^{\circ} 09.009^{\prime}$ \\
\hline MA-081395 & MB 2-3 & main lode, mining dump Danielstollen & $47^{\circ} 24.696^{\prime}$ & $13^{\circ} 09.009^{\prime}$ \\
\hline MA-081396 & MB 2-4 & main lode, mining dump Danielstollen & $47^{\circ} 24.696^{\prime}$ & $13^{\circ} 09.009^{\prime}$ \\
\hline MA-081397 & MB 2-5 & main lode, mining dump Danielstollen & $47^{\circ} 24.696^{\prime}$ & $13^{\circ} 09.009^{\prime}$ \\
\hline MA-081398 & MB 2-6 & main lode, mining dump Danielstollen & $47^{\circ} 24.696^{\prime}$ & $13^{\circ} 09.009^{\prime}$ \\
\hline MA-081399 & MB 18 & Winkel lode, mining dump Im Naglgraben & $47^{\circ} 23.680^{\prime}$ & $13^{\circ} 14.583^{\prime}$ \\
\hline MA-081400 & MB 19 & Winkel lode, mining dump & $47^{\circ} 23.682^{\prime}$ & $13^{\circ} 14.683^{\prime}$ \\
\hline MA-081401 & MB 20-1 & Burgschwaig lode, mining dump Oberer Palfner-Schurfstollen & $47^{\circ} 22.792^{\prime}$ & $13^{\circ} 10.561^{\prime}$ \\
\hline MA-081402 & MB 20-2 & Burgschwaig lode, mining dump Oberer Palfner-Schurfstollen & $47^{\circ} 22.792^{\prime}$ & $13^{\circ} 10.561^{\prime}$ \\
\hline
\end{tabular}


Tab. 3. continued.

\begin{tabular}{|c|c|c|c|c|}
\hline Lab no. & Field label & Location & $\mathbf{N}$ & E \\
\hline MA-081403 & MB 20-3 & Burgschwaig lode, mining dump Oberer Palfner-Schurfstollen & $47^{\circ} 22.792^{\prime}$ & $13^{\circ} 10.561^{\prime}$ \\
\hline MA-081404 & MB 20-4 & Burgschwaig lode, mining dump Oberer Palfner-Schurfstollen & $47^{\circ} 22.792^{\prime}$ & $13^{\circ} 10.561^{\prime}$ \\
\hline MA-081405 & MB 21-1 & Buchberg lode, mining dump Oberer Buchbergstollen & $47^{\circ} 24.327^{\prime}$ & $13^{\circ} 14.339^{\prime}$ \\
\hline MA-081406 & MB 21-2 & Buchberg lode, mining dump Oberer Buchbergstollen & $47^{\circ} 24.327^{\prime}$ & $13^{\circ} 14.339^{\prime}$ \\
\hline MA-081407 & MB 21-3 & Buchberg lode, mining dump Oberer Buchbergstollen & $47^{\circ} 24.327^{\prime}$ & $13^{\circ} 14.339^{\prime}$ \\
\hline MA-081408 & MB 21-4 & Buchberg lode, mining dump Oberer Buchbergstollen & $47^{\circ} 24.327^{\prime}$ & $13^{\circ} 14.339^{\prime}$ \\
\hline MA-081409 & MB 7-1 & main lode, stream bed near Maria-Hilf-Stollen & $47^{\circ} 24.165^{\prime}$ & $13^{\circ} 07.207^{\prime}$ \\
\hline MA-081410 & MB 7-2 & main lode, stream bed near Maria-Hilf-Stollen & $47^{\circ} 24.165^{\prime}$ & $13^{\circ} 07.207^{\prime}$ \\
\hline MA-081411 & MB 7-3 & main lode, stream bed near Maria-Hilf-Stollen & $47^{\circ} 24.165^{\prime}$ & $13^{\circ} 07.207^{\prime}$ \\
\hline MA-081412 & MB 7-4 & main lode, stream bed near Maria-Hilf-Stollen & $47^{\circ} 24.165^{\prime}$ & $13^{\circ} 07.207^{\prime}$ \\
\hline MA-081413 & MB 7-5 & main lode, stream bed near Maria-Hilf-Stollen & $47^{\circ} 24.165^{\prime}$ & $13^{\circ} 07.207^{\prime}$ \\
\hline MA-081414 & MB 7-6 & main lode, stream bed near Maria-Hilf-Stollen & $47^{\circ} 24.165^{\prime}$ & $13^{\circ} 07.207^{\prime}$ \\
\hline MA-081415 & MB 7-7 & main lode, stream bed near Maria-Hilf-Stollen & $47^{\circ} 24.165^{\prime}$ & $13^{\circ} 07.207^{\prime}$ \\
\hline MA-081416 & MB 7-8 & main lode, stream bed near Maria-Hilf-Stollen & $47^{\circ} 24.165^{\prime}$ & $13^{\circ} 07.207^{\prime}$ \\
\hline MA-081417 & MB 9-1 & main lode, stream bed near Josefi-Oberbau-Stollen & - & - \\
\hline MA-081418 & MB 9-2 & main lode, stream bed near Josefi-Oberbau-Stollen & - & - \\
\hline MA-081419 & MB 9-3 & main lode, stream bed near Josefi-Oberbau-Stollen & - & - \\
\hline MA-081420 & MB 9-4 & main lode, stream bed near Josefi-Oberbau-Stollen & - & - \\
\hline MA-081421 & MB 9-5 & main lode, stream bed near Josefi-Oberbau-Stollen & - & - \\
\hline MA-081422 & MB 9-6 & main lode, stream bed near Josefi-Oberbau-Stollen & - & - \\
\hline MA-081423 & MB-10 & main lode, stream bed beside Maria-Hilf-Stollen & $47^{\circ} 24.407^{\prime}$ & $13^{\circ} 07.423^{\prime}$ \\
\hline MA-081424 & MB 11-1 & main lode, streambed near Josefi-Unterbau-Stollen & - & - \\
\hline MA-081425 & MB 11-2 & main lode, streambed near Josefi-Unterbau-Stollen & - & - \\
\hline MA-081426 & MB 11-3 & main lode, streambed near Josefi-Unterbau-Stollen & - & - \\
\hline MA-081427 & MB 11-4 & main lode, streambed near Josefi-Unterbau-Stollen & - & - \\
\hline MA-081428 & MB 11-5 & main lode, streambed near Josefi-Unterbau-Stollen & - & - \\
\hline MA-081429 & MB 11-6 & main lode, streambed near Josefi-Unterbau-Stollen & - & - \\
\hline MA-081430 & MB 11-7 & main lode, streambed near Josefi-Unterbau-Stollen & - & - \\
\hline MA-081624 & MB 21-5 & Buchberg lode, mining dump Oberer Buchbergstollen & $47^{\circ} 24.327^{\prime}$ & $13^{\circ} 14.339^{\prime}$ \\
\hline MA-081625 & MB 21-6 & Buchberg lode, mining dump Oberer Buchbergstollen & $47^{\circ} 24.327^{\prime}$ & $13^{\circ} 14.339^{\prime}$ \\
\hline MA-081626 & MB 19-2 & Winkel lode, dump beside test trench & $47^{\circ} 23.682^{\prime}$ & $13^{\circ} 14.683^{\prime}$ \\
\hline MA-081627 & MB 19-3 & Winkel lode, dump beside test trench & $47^{\circ} 23.682^{\prime}$ & $13^{\circ} 14.683^{\prime}$ \\
\hline MA-081628 & MB 26-1 & Burgschwaig lode, mining dump Luisenstollen & $47^{\circ} 22.216^{\prime}$ & $13^{\circ} 11.279^{\prime}$ \\
\hline MA-081629 & MB 26-2 & Burgschwaig lode, mining dump Luisenstollen & $47^{\circ} 22.216^{\prime}$ & $13^{\circ} 11.279^{\prime}$ \\
\hline MA-081630 & MB 26-3 & Burgschwaig lode, mining dump Luisenstollen & $47^{\circ} 22.216^{\prime}$ & $13^{\circ} 11.279^{\prime}$ \\
\hline MA-081631 & MB 26-4 & Burgschwaig lode, mining dump Luisenstollen & $47^{\circ} 22.216^{\prime}$ & $13^{\circ} 11.279^{\prime}$ \\
\hline MA-081632 & MB 26-5 & Burgschwaig lode, mining dump Luisenstollen & $47^{\circ} 22.216^{\prime}$ & $13^{\circ} 11.279^{\prime}$ \\
\hline MA-081633 & MB 26-6 & Burgschwaig lode, mining dump Luisenstollen & $47^{\circ} 22.216^{\prime}$ & $13^{\circ} 11.279^{\prime}$ \\
\hline MA-081634 & MB 25-1 & Taghaube & $47^{\circ} 23.905^{\prime}$ & $13^{\circ} 03.674^{\prime}$ \\
\hline MA-081635 & MB 25-2 & Taghaube & $47^{\circ} 23.905^{\prime}$ & $13^{\circ} 03.674^{\prime}$ \\
\hline MA-100344 & MB 9-1-1 & Buchberg lode & - & - \\
\hline MA-100345 & MB 9-1-2 & Buchberg lode & - & - \\
\hline MA-100346 & MB 9-1-3 & Buchberg lode & - & - \\
\hline MA-100347 & MB-9-1-4 & Buchberg lode & - & - \\
\hline
\end{tabular}


Tab. 3. continued.

\begin{tabular}{|c|c|c|c|c|}
\hline Lab no. & Field label & Location & $\mathbf{N}$ & $\mathrm{E}$ \\
\hline MA-100348 & MB- 9-1-5 & Buchberg lode & - & - \\
\hline MA-100349 & MB 9-2-1 & Winkel lode, prehistoric dump & - & - \\
\hline MA-100350 & MB 9-2-2 & Winkel lode, prehistoric dump & - & - \\
\hline MA-100351 & MB 9-3-1 & Winkel lode, mining dump Arzbergstollen & - & - \\
\hline MA-100352 & MB 9-3-2 & Winkel lode, mining dump Arzbergstollen & - & - \\
\hline MA-100353 & MB 9-3-3 & Winkel lode, mining dump Arzbergstollen & - & - \\
\hline MA-100354 & MB 9-3-4 & Winkel lode, mining dump Arzbergstollen & - & - \\
\hline MA-100355 & Vieh-1-1 & Viehhofen, prehistoric mining dump north of Viehhofen & - & - \\
\hline MA-100356 & Vieh-1-2 & Viehhofen, prehistoric mining dump north of Viehhofen & - & - \\
\hline MA-100357 & Vieh-1-3 & Viehhofen, prehistoric mining dump north of Viehhofen & - & - \\
\hline MA-100358 & Vieh-1-4 & Viehhofen, prehistoric mining dump north of Viehhofen & - & - \\
\hline MA-100359 & Vieh-2-1 & Viehhofen, quarry east of Viehhofen & - & - \\
\hline MA-080975 & KE 1 & Kitzbühel-Jochberg, Kelchalm & - & - \\
\hline MA-080976 & KE 2 & Kitzbühel-Jochberg, Kelchalm & - & - \\
\hline MA-080979 & KE 27 & Kitzbühel-Jochberg, Kelchalm & - & - \\
\hline MA-080981 & KE 28 & Kitzbühel-Jochberg, Kelchalm & - & - \\
\hline MA-080980 & KE 28a & Kitzbühel-Jochberg, Kelchalm & - & - \\
\hline MA-080977 & KE 3 & Kitzbühel-Jochberg, Kelchalm & - & - \\
\hline MA-080982 & KE 32 & Kitzbühel-Jochberg, Kelchalm & - & - \\
\hline MA-080983 & KE 34 & Kitzbühel-Jochberg, Kelchalm & - & - \\
\hline MA-080984 & KE 35 & Kitzbühel-Jochberg, Kelchalm & - & - \\
\hline MA-080985 & $\mathrm{KE} 43$ & Kitzbühel-Jochberg, Kelchalm & - & - \\
\hline MA-080978 & KE 5 & Kitzbühel-Jochberg, Kelchalm & - & - \\
\hline MA-081637 & KE 6 & Kitzbühel-Jochberg, Kelchalm & - & - \\
\hline MA-081638 & KES 7 & Kitzbühel-Jochberg, Kelchalm & - & - \\
\hline MA-081639 & KE 43a & Kitzbühel-Jochberg, Kelchalm & - & - \\
\hline MA-080989 & KP 1 & Kitzbühel-Jochberg, Kupferplatte & - & - \\
\hline
\end{tabular}


Tab. 4. Element concentrations in ore samples from the Mitterberg region as determined by instrumental neutron activation analysis $(\mathrm{Cu}, \mathrm{Fe}$, $\mathrm{As}, \mathrm{Sb}, \mathrm{Co}, \mathrm{Ni}, \mathrm{Ag}, \mathrm{Au}, \mathrm{Zn}, \mathrm{Sn}, \mathrm{Se}, \mathrm{Te})$ and inductively coupled mass spectrometry (Pb, Bi); n.a. = not analysed; <= below detection limit.

\begin{tabular}{|c|c|c|c|c|c|c|c|c|c|c|c|c|c|c|}
\hline Lab no. & $\begin{array}{c}\mathrm{Cu} \\
\%\end{array}$ & $\begin{array}{l}\mathrm{Fe} \\
\%\end{array}$ & $\begin{array}{c}\text { As } \\
\mu \mathrm{g} / \mathrm{g}\end{array}$ & $\begin{array}{c}\mathrm{Sb} \\
\mu \mathrm{g} / \mathrm{g}\end{array}$ & $\begin{array}{c}\text { Co } \\
\mu g / g\end{array}$ & $\begin{array}{c}\mathrm{Ni} \\
\mu \mathrm{g} / \mathrm{g}\end{array}$ & $\begin{array}{c}\mathrm{Ag} \\
\mu \mathrm{g} / \mathrm{g}\end{array}$ & $\begin{array}{c}\mathrm{Au} \\
\mu \mathrm{g} / \mathrm{g}\end{array}$ & $\begin{array}{c}\mathrm{Zn} \\
\mu \mathrm{g} / \mathrm{g}\end{array}$ & $\begin{array}{c}\text { Sn } \\
\mu \mathrm{g} / \mathrm{g}\end{array}$ & $\begin{array}{c}\mathrm{Se} \\
\mu \mathrm{g} / \mathrm{g}\end{array}$ & $\begin{array}{c}\mathrm{Te} \\
\mu \mathrm{g} / \mathrm{g}\end{array}$ & $\begin{array}{c}\mathrm{Pb} \\
\mu \mathrm{g} / \mathrm{g}\end{array}$ & $\begin{array}{r}\mathrm{Bi} \\
\mu \mathrm{g} / \mathrm{g}\end{array}$ \\
\hline MA-080582 & 22.8 & 16.0 & 291 & 16.3 & 8.2 & 124 & 6.6 & 0.12 & 89 & $<110$ & 5 & $<6$ & 24.4 & 25.0 \\
\hline MA-080583 & 15.3 & 23.6 & 3800 & 40 & 890 & 2330 & 10.1 & 0.20 & 156 & $<109$ & 47 & 13 & 27.2 & 35 \\
\hline MA-080584 & 28.1 & 21.5 & 1340 & 1340 & 241 & 1250 & 10.1 & 0.53 & 930 & $<100$ & 43 & 8 & 13.0 & 10.4 \\
\hline MA-080585 & 7.0 & 21.2 & 8400 & 40 & 630 & 1040 & 4.4 & 0.29 & 89 & $<66$ & 37 & 8 & 32 & 19.4 \\
\hline MA-080586 & 7.2 & 12.6 & 1690 & 201 & 660 & 840 & 7.5 & 0.17 & 190 & 44 & 20 & $<15$ & 15.3 & 13.6 \\
\hline MA-080587 & 11.4 & 18.3 & 1590 & 17.3 & 450 & 1050 & 5.9 & 0.40 & 119 & $<148$ & 23 & $<9$ & 20.8 & 13.6 \\
\hline MA-080588 & 18.7 & 19.0 & 3000 & 57 & 720 & 1480 & 13.5 & 0.24 & 219 & $<69$ & 32 & $<12$ & 18.0 & 18.1 \\
\hline MA-080589 & 7.8 & 9.5 & 2780 & 120 & 1090 & 880 & 6.0 & 1.04 & 136 & $<215$ & 25 & 10 & 10.7 & 25.2 \\
\hline MA-081367 & 20.1 & 14.8 & 63 & 7.0 & 1.50 & $<150$ & 12.4 & 0.05 & 85 & $<89$ & 2.4 & $<6$ & 4.1 & 0.18 \\
\hline MA-081368 & 22.5 & 17.1 & 69 & 9.6 & 6.5 & $<159$ & 14.5 & 0.15 & 89 & $<77$ & 4.6 & $<7$ & 3.1 & 0.26 \\
\hline MA-081369 & 25.0 & 17.6 & 33 & 26.2 & 2.71 & 104 & 14.1 & 0.11 & 255 & $<207$ & 7.3 & 3 & 7.2 & 0.32 \\
\hline MA-081370 & 20.0 & 19.1 & 440 & 29.8 & 69 & 153 & 20.4 & 0.20 & 82 & $<248$ & 7.9 & $<9$ & 12.8 & 1.73 \\
\hline MA-081371 & 16.0 & 24.9 & 720 & 207 & 66 & 235 & 16.1 & 0.46 & 99 & 40 & 8.0 & $<10$ & n.a. & n.a. \\
\hline MA-081372 & 30 & 20.9 & 141 & 49 & 15.1 & $<152$ & 19.4 & 0.14 & 650 & $<105$ & 37 & 5 & 23.5 & 0.51 \\
\hline MA-081373 & 25.0 & 18.4 & 134 & 24.7 & 15.5 & 92 & 19.1 & 0.23 & 330 & 32 & 7.6 & $<8$ & 5.8 & 0.61 \\
\hline MA-081374 & 17.3 & 22.4 & 420 & 27.6 & 81 & $<179$ & 5.2 & 0.25 & 139 & 41 & 7.6 & $<9$ & n.a. & n.a. \\
\hline MA-081375 & 27.3 & 15.2 & 55 & 9.7 & 5.9 & 86 & 10.7 & 0.17 & 188 & 35 & 5.9 & 5 & 11.9 & 0.39 \\
\hline MA-081376 & 21.9 & 12.7 & 86 & 11.8 & 13.0 & 142 & 21.6 & 0.30 & 60 & $<60$ & 4.9 & $<8$ & n.a. & n.a. \\
\hline MA-081377 & 33 & 17.8 & 5.9 & 3.9 & 41 & 350 & 47 & 0.10 & 1810 & 146 & 25.7 & 4 & 12.1 & 0.21 \\
\hline MA-081378 & 10.2 & 12.6 & 17000 & 156 & 770 & 13000 & 17.1 & 0.34 & 254 & $<140$ & 16.8 & $<30$ & 12.0 & 2.12 \\
\hline MA-081379 & 8.9 & 10.2 & 1440 & 39 & 264 & 2760 & 11.1 & 0.16 & 75 & $<207$ & 14.2 & 6 & 21.2 & 1.84 \\
\hline MA-081380 & 28.6 & 17.4 & 480 & 27.4 & 162 & 910 & 14.0 & 0.37 & 271 & $<216$ & 44 & $<9$ & 61 & 1.76 \\
\hline MA-081381 & 13.7 & 22.5 & 660 & 135 & 520 & 1030 & 6.4 & 0.90 & 118 & 48 & 65 & 5 & 59 & 5.6 \\
\hline MA-081382 & 20.2 & 14.5 & 1180 & 124 & 320 & 780 & 10.2 & 0.61 & 420 & 40 & 34 & $<13$ & n.a. & n.a. \\
\hline MA-081383 & 3.0 & 19.0 & 610 & 9.3 & 1770 & 2210 & 3.1 & 0.14 & 400 & $<530$ & 18.3 & $<41$ & 6.9 & 2.14 \\
\hline MA-081384 & 15.7 & 11.7 & 1870 & 490 & 450 & 1380 & 20.8 & 0.32 & 171 & $<300$ & 28.4 & $<20$ & 58 & 9.6 \\
\hline MA-081385 & 22.6 & 15.4 & 800 & 12.1 & 35 & 630 & 13.7 & 0.14 & 99 & $<154$ & 12.4 & $<11$ & 8.4 & 0.57 \\
\hline MA-081386 & 16.2 & 13.9 & 300 & 8.2 & 58 & 233 & 3.0 & 0.08 & 72 & $<65$ & 14.3 & $<9$ & 10.5 & 1.45 \\
\hline MA-081387 & 19.8 & 16.6 & 216 & 11.8 & 64 & 225 & 6.3 & 0.07 & 270 & $<112$ & 21.8 & $<10$ & n.a. & n.a. \\
\hline MA-081388 & 17.6 & 11.7 & 820 & 27.8 & 7.2 & 490 & 5.4 & 0.35 & 64 & $<34$ & 10.5 & 3 & n.a. & n.a. \\
\hline MA-081389 & 21.1 & 14.4 & 3900 & 20.3 & 59 & 1950 & 23.2 & 0.18 & 570 & 85 & 12.4 & 10 & 32 & 1.27 \\
\hline MA-081390 & 26.9 & 18.2 & 3400 & 23.8 & 61 & 2320 & 7.9 & 0.31 & 77 & 58 & 19.6 & $<14$ & 11.4 & 1.16 \\
\hline MA-081391 & 20.8 & 19.0 & 11000 & 58 & 224 & 8000 & 3.7 & 0.40 & 60 & $<205$ & 15.0 & $<17$ & 23.3 & 4.6 \\
\hline MA-081392 & 19.6 & 15.7 & 1550 & 28.8 & 116 & 1070 & 6.7 & 0.17 & 200 & $<168$ & 17.8 & 13 & 96 & 2.33 \\
\hline MA-081393 & 22.6 & 21.2 & 410 & 7.9 & 53 & 143 & 8.4 & 0.15 & 121 & 62 & 8.8 & 15 & n.a. & n.a. \\
\hline MA-081394 & 19.7 & 27.8 & 610 & 4.2 & 850 & 1010 & 10.0 & 0.79 & 53 & 201 & 36 & $<27$ & 9.3 & 12.4 \\
\hline MA-081395 & 17.9 & 19.7 & 132 & 20.7 & 18.2 & 161 & 7.6 & 0.09 & 203 & $<320$ & 16.5 & $<21$ & 9.4 & 1.45 \\
\hline MA-081396 & 30 & 27.5 & 20200 & 138 & 22.0 & 1360 & 32 & 0.24 & 3800 & $<390$ & 11.4 & $<26$ & 300 & 2.13 \\
\hline MA-081397 & 12.8 & 14.4 & 13200 & 76 & 219 & 9100 & 16.4 & 0.64 & 74 & 74 & 17.4 & $<21$ & n.a. & n.a. \\
\hline MA-081398 & 9.5 & 15.7 & 650 & 72 & 285 & 490 & 8.6 & 0.16 & 259 & $<330$ & 9.0 & $<25$ & n.a. & n.a. \\
\hline MA-081399 & 8.5 & 10.4 & 370 & 202 & 51 & 223 & 9.2 & 1.24 & 67 & $<223$ & 66 & 78 & 69 & 1310 \\
\hline MA-081400 & 17.6 & 0.50 & 360 & 1.84 & 330 & 87 & $<3$ & $<0.1$ & 62 & 53 & 4.9 & 7 & n.a. & n.a. \\
\hline
\end{tabular}


Tab. 4. continued.

\begin{tabular}{|c|c|c|c|c|c|c|c|c|c|c|c|c|c|c|}
\hline Lab no. & $\begin{array}{c}\mathrm{Cu} \\
\%\end{array}$ & $\begin{array}{l}\mathrm{Fe} \\
\%\end{array}$ & $\begin{array}{c}\text { As } \\
\mu \mathrm{g} / \mathrm{g}\end{array}$ & $\begin{array}{c}\mathrm{Sb} \\
\mu \mathrm{g} / \mathrm{g}\end{array}$ & $\begin{array}{c}\text { Co } \\
\mu \mathrm{g} / \mathrm{g}\end{array}$ & $\begin{array}{c}\mathrm{Ni} \\
\mu \mathrm{g} / \mathrm{g}\end{array}$ & $\begin{array}{c}\mathrm{Ag} \\
\mu \mathrm{g} / \mathrm{g}\end{array}$ & $\begin{array}{r}\mathrm{Au} \\
\mu \mathrm{g} / \mathrm{g}\end{array}$ & $\begin{array}{c}\mathrm{Zn} \\
\mu \mathrm{g} / \mathrm{g}\end{array}$ & $\begin{array}{c}\mathrm{Sn} \\
\mu \mathrm{g} / \mathrm{g}\end{array}$ & $\begin{array}{c}\mathrm{Se} \\
\mu \mathrm{g} / \mathrm{g}\end{array}$ & $\begin{array}{c}\mathrm{Te} \\
\mu \mathrm{g} / \mathrm{g}\end{array}$ & $\begin{array}{c}\mathrm{Pb} \\
\mu \mathrm{g} / \mathrm{g}\end{array}$ & $\begin{array}{c}\text { Bi } \\
\mu \mathrm{g} / \mathrm{g}\end{array}$ \\
\hline MA-081401 & 17.5 & 17.5 & 1050 & 14.1 & 95 & 910 & 21.2 & 0.14 & 262 & $<130$ & 12.0 & 4 & 5.5 & 0.22 \\
\hline MA-081402 & 10.3 & 19.6 & 1830 & 22.8 & 670 & 1960 & 12.7 & 0.19 & 106 & $<99$ & 13.1 & 6 & 13.9 & 1.06 \\
\hline MA-081403 & 25.8 & 19.4 & 254 & 8.4 & 34 & 1700 & 36 & 0.27 & 480 & $<81$ & 15.5 & 4 & 8.8 & 0.13 \\
\hline MA-081404 & 12.8 & 18.3 & 1510 & 16.0 & 350 & 1670 & 16.7 & 0.16 & 220 & $<139$ & 12.6 & 7 & n.a. & n.a. \\
\hline MA-081405 & 9.4 & 8.0 & 310 & 19.2 & 230 & 274 & 15.9 & 0.64 & 1050 & 42 & 6.3 & 5 & 134 & 1.41 \\
\hline MA-081406 & 2.36 & 16.7 & 320 & 31 & 290 & 215 & 4 & 0.12 & 14.8 & 56 & 4.4 & $<7$ & 18.6 & 9.6 \\
\hline MA-081407 & 4.2 & 19.4 & 148 & 8.7 & 410 & 480 & $<2$ & 0.09 & 68 & $<200$ & 13.6 & $<10$ & n.a. & n.a. \\
\hline MA-081408 & 12.3 & 8.6 & 271 & 10.8 & 18.2 & $<117$ & 13.2 & 0.06 & 400 & $<58$ & 3.9 & 5 & 19.7 & 0.47 \\
\hline MA-081409 & 33 & 17.4 & 3300 & 13.1 & 103 & 1510 & 10.3 & 0.57 & 277 & 117 & 9.1 & $<6$ & 42 & 3.2 \\
\hline MA-081410 & 16.8 & 16.2 & 650 & 46 & 137 & 1200 & 7.5 & 0.15 & 18.8 & 89 & 9.2 & $<6$ & n.a. & n.a. \\
\hline MA-081411 & 21.8 & 15.8 & 9300 & 71 & 147 & 6100 & 20.1 & 0.81 & 205 & 55 & 18.4 & $<7$ & n.a. & n.a. \\
\hline MA-081412 & 24.5 & 14.0 & 1160 & 197 & 71 & 510 & 6.4 & 0.09 & 130 & $<202$ & 26.3 & $<8$ & n.a. & n.a. \\
\hline MA-081413 & 21.1 & 14.0 & 14600 & 68 & 287 & 8100 & 17.2 & 0.23 & 164 & 40 & 15.6 & $<8$ & n.a. & n.a. \\
\hline MA-081414 & 23.8 & 14.0 & 4700 & 38 & 89 & 2030 & 9.3 & 0.52 & 420 & 93 & 7.8 & 4 & n.a. & n.a. \\
\hline MA-081415 & 21.9 & 12.4 & 4600 & 35 & 109 & 2560 & 11.4 & 0.39 & 132 & 35 & 6.1 & $<7$ & n.a. & n.a. \\
\hline MA-081416 & 14.3 & 18.4 & 1910 & 28.9 & 39 & 1220 & 8.4 & 0.48 & 51 & $<34$ & 10.3 & $<7$ & n.a. & n.a. \\
\hline MA-081417 & 19.2 & 14.0 & 310 & 47 & 18.7 & 520 & 6.0 & 0.19 & 31 & $<297$ & $<10$ & $<13$ & n.a. & n.a. \\
\hline MA-081418 & 10.2 & 18.9 & 1290 & 95 & 112 & 219 & $<4$ & $<0.1$ & 31 & $<440$ & 21.4 & $<20$ & 9.0 & 2.21 \\
\hline MA-081419 & 22.6 & 14.2 & 38 & 47 & 59 & 48 & 8.3 & 0.07 & 25.5 & $<123$ & 13.0 & 6 & n.a. & n.a. \\
\hline MA-081420 & 16.2 & 8.1 & 330 & 32 & 11.4 & 310 & 4.9 & 0.14 & 25.1 & $<276$ & 4.6 & 6 & n.a. & n.a. \\
\hline MA-081421 & 5.0 & 21.1 & 3600 & 3300 & 191 & 390 & 65 & 0.18 & 640 & $<710$ & 23.4 & $<27$ & n.a. & n.a. \\
\hline MA-081422 & 19.9 & 25.9 & 1220 & 80 & 141 & 1190 & 12.8 & 0.18 & 155 & 126 & 16.8 & $<7$ & n.a. & n.a. \\
\hline MA-081423 & 20.0 & 20.2 & 3100 & 11.1 & 85 & 1450 & 6.6 & 0.43 & 62 & 53 & 2.2 & $<6$ & 7.6 & 3.8 \\
\hline MA-081424 & 19.6 & 17.9 & 13200 & 66 & 320 & 6600 & 8.5 & 0.12 & 115 & 32 & 25.2 & $<9$ & n.a. & n.a. \\
\hline MA-081425 & 19.0 & 17.6 & 119 & 17.3 & 21.1 & $<173$ & 21.8 & 0.04 & 158 & $<156$ & 13.1 & $<11$ & n.a. & n.a. \\
\hline MA-081426 & 29.7 & 18.4 & 650 & 27.0 & 9.9 & 400 & $<10$ & 0.15 & 198 & $<330$ & 14.8 & 14 & n.a. & n.a. \\
\hline MA-081427 & 21.3 & 13.4 & 3500 & 153 & 65 & 1530 & 17.4 & 0.21 & 284 & $<340$ & 9.6 & $<13$ & n.a. & n.a. \\
\hline MA-081428 & 21.1 & 18.5 & 196 & 32 & 147 & 278 & $<2$ & 0.15 & 32 & $<68$ & 22.2 & $<9$ & 49 & 1.34 \\
\hline MA-081429 & 13.5 & 12.6 & 11400 & 94 & 173 & 7800 & 17.5 & 0.71 & 78 & $<340$ & 16.4 & $<13$ & n.a. & n.a. \\
\hline MA-081430 & 27.8 & 17.8 & 1930 & 23.7 & 77 & 1400 & 15.6 & 0.15 & $<21$ & $<310$ & 11.1 & $<14$ & n.a. & n.a. \\
\hline MA-081624 & 13.5 & 17.4 & 480 & 18.8 & 370 & 720 & 7.9 & 0.13 & 217 & $<37$ & 4.9 & 3 & 25.5 & 2.21 \\
\hline MA-081625 & 9.4 & 8.5 & 88 & 5.2 & 59 & 262 & 5.0 & 0.15 & 125 & $<108$ & 2.1 & $<5$ & 9.3 & 0.55 \\
\hline MA-081626 & 4.5 & 3.5 & 222 & 44 & 6.5 & 24 & 2.8 & 0.06 & 23.0 & 17 & 20.3 & $<5$ & 2.66 & 1.15 \\
\hline MA-081627 & 8.0 & 5.6 & 330 & 4.8 & 5.9 & 22 & 9.6 & 0.09 & 108 & 24 & 19.8 & 1 & 52 & 0.80 \\
\hline MA-081628 & 19.7 & 12.9 & 7.7 & 11.1 & 15.9 & 500 & 7.4 & 0.16 & 136 & $<122$ & 10.6 & $<6$ & 43 & 0.11 \\
\hline MA-081629 & 19.0 & 13.9 & 1670 & 12.9 & 279 & 2070 & 13.4 & 0.21 & 380 & $<153$ & 8.4 & $<8$ & 32 & 1.60 \\
\hline MA-081630 & 14.0 & 11.5 & 1850 & 23.4 & 360 & 9100 & 10.0 & 0.16 & 200 & 27 & 5.3 & 7 & 28.0 & 1.14 \\
\hline MA-081631 & 22.7 & 15.5 & 145 & 6.9 & 115 & 9200 & 6.5 & 0.11 & 100 & $<47$ & 2.5 & $<1$ & 17.9 & 0.78 \\
\hline MA-081632 & 10.2 & 14.0 & 55 & 11.0 & 260 & 12600 & 11.4 & 0.05 & 31 & $<330$ & 5.3 & $<14$ & n.a. & n.a. \\
\hline MA-081633 & 18.1 & 15.9 & 280 & 28.3 & 73 & 6300 & 11.3 & 0.06 & 37 & 320 & 3.7 & $<13$ & 7.1 & 0.26 \\
\hline MA-081634 & 14.0 & 31 & 370 & 530 & 102 & 271 & 34 & 0.06 & 68 & $<470$ & 13.2 & $<21$ & 5.5 & 1.79 \\
\hline MA-081635 & 12.8 & 33 & 400 & 340 & 212 & 740 & 21.9 & 0.09 & 60 & $<390$ & 13.9 & $<18$ & 14.4 & 4.2 \\
\hline
\end{tabular}


Tab. 4. continued.

\begin{tabular}{|c|c|c|c|c|c|c|c|c|c|c|c|c|c|c|}
\hline Lab no. & $\begin{array}{c}\mathrm{Cu} \\
\%\end{array}$ & $\begin{array}{l}\mathrm{Fe} \\
\%\end{array}$ & $\begin{array}{c}\text { As } \\
\mu \mathrm{g} / \mathrm{g}\end{array}$ & $\begin{array}{c}\mathrm{Sb} \\
\mu \mathrm{g} / \mathrm{g}\end{array}$ & $\begin{array}{c}\text { Co } \\
\mu \mathrm{g} / \mathrm{g}\end{array}$ & $\begin{array}{c}\mathrm{Ni} \\
\mu \mathrm{g} / \mathrm{g}\end{array}$ & $\begin{array}{c}\mathrm{Ag} \\
\mu \mathrm{g} / \mathrm{g}\end{array}$ & $\begin{array}{c}\mathrm{Au} \\
\mu \mathrm{g} / \mathrm{g}\end{array}$ & $\begin{array}{c}\mathrm{Zn} \\
\mu \mathrm{g} / \mathrm{g}\end{array}$ & $\begin{array}{c}\text { Sn } \\
\mu \mathrm{g} / \mathrm{g}\end{array}$ & $\begin{array}{c}\mathrm{Se} \\
\mu \mathrm{g} / \mathrm{g}\end{array}$ & $\begin{array}{c}\mathrm{Te} \\
\mu \mathrm{g} / \mathrm{g}\end{array}$ & $\begin{array}{c}\mathrm{Pb} \\
\mu \mathrm{g} / \mathrm{g}\end{array}$ & $\begin{array}{c}\mathrm{Bi} \\
\mu \mathrm{g} / \mathrm{g}\end{array}$ \\
\hline MA-100344 & 3.7 & 8.2 & 51 & 8.4 & 67 & 50 & 4.8 & 0.02 & 40 & $<35$ & 2.2 & $<7$ & 5.4 & 0.6 \\
\hline MA-100345 & 6.1 & 10.5 & 69 & 2.35 & 155 & 130 & 7 & 0.06 & 124 & $<130$ & 2.4 & 2 & 5.6 & 0.3 \\
\hline MA-100346 & 4.5 & 12.5 & 211 & 4.7 & 186 & 200 & 6.4 & 0.137 & 64 & $<130$ & 3.2 & $<7$ & 7.0 & 1.6 \\
\hline MA-100347 & 7.0 & 10.9 & 151 & 3.6 & 16.4 & 50 & 4.6 & 0.029 & 140 & $<58$ & 2.5 & $<7$ & 4.5 & 0.1 \\
\hline MA-100348 & 11.7 & 12.2 & 77 & 3.7 & 48 & 60 & 7.7 & 0.03 & 194 & $<120$ & 3 & $<7$ & 8.8 & 0.5 \\
\hline MA-100349 & 11.3 & 10.8 & 650 & 85 & 100 & 50 & 10.5 & 0.095 & 147 & $<120$ & 52 & $<8$ & 136 & 3.9 \\
\hline MA-100350 & 5.9 & 6.6 & 360 & 10.6 & 23 & 110 & 8.8 & 0.144 & 90 & $<34$ & 32 & 3 & 10.5 & 2.4 \\
\hline MA-100351 & 27.8 & 25.0 & 650 & 25.7 & 61 & 360 & 62 & 1.7 & 2040 & 80 & 20.6 & $<9$ & 40 & 6.3 \\
\hline MA-100352 & 3.4 & 9.7 & 66000 & 144 & 1160 & 90 & 13.6 & $<0.2$ & 180 & $<81$ & 18.7 & $<16$ & 23.8 & 23.4 \\
\hline MA-100353 & 6.6 & 9.1 & 1190 & 16.6 & 175 & 90 & 6.5 & 0.11 & 239 & $<150$ & 19 & $<10$ & 7.1 & 2.0 \\
\hline MA-100354 & 5.1 & 4.3 & 1840 & 6.8 & 127 & 60 & 11.3 & 0.13 & 160 & $<110$ & 15.2 & 6 & 5.5 & 4.8 \\
\hline MA-100355 & 7.1 & 12.5 & 620 & 15.6 & 220 & 510 & 16.7 & 0.168 & 44 & 60 & 18.5 & $<9$ & 24.2 & 1.5 \\
\hline MA-100356 & 5.0 & 8.1 & 470 & 7.8 & 146 & 420 & 8.4 & 0.085 & 34 & $<110$ & 35 & $<8$ & 13.7 & 1.8 \\
\hline MA-100357 & 5.4 & 8.8 & 490 & 6.7 & 127 & 440 & 9.7 & 0.08 & 27 & $<47$ & 29.8 & $<9$ & 13.5 & 2.2 \\
\hline MA-100358 & 6.9 & 6.6 & 144 & 3.8 & 35 & 110 & 11.9 & 0.032 & 28 & $<100$ & 10.5 & 3 & 8.2 & 0.5 \\
\hline MA-100359 & 47 & 16.4 & 540 & 7.6 & 300 & 1260 & 9 & 0.15 & 71 & $<150$ & 145 & $<12$ & 14.2 & 1.8 \\
\hline MA-080975 & 16.6 & 9.9 & 370 & 10.9 & 148 & 224 & 23.4 & 0.15 & 91 & $<125$ & 14 & 6 & 13.1 & 20.6 \\
\hline MA-080976 & 27.7 & 15.5 & 4.0 & 5.6 & 4.7 & 48 & 12.9 & 0.12 & 48 & $<60$ & 133 & 4 & 21.8 & 12.2 \\
\hline MA-080979 & 12.5 & 18.3 & 17.4 & 7.1 & 155 & 750 & 4.1 & 0.41 & 15 & $<68$ & 139 & 10 & 30 & 51 \\
\hline MA-080981 & 14.6 & 13.6 & 98 & 8.2 & 77 & 283 & 5.5 & 0.21 & 12 & $<159$ & 110 & $<16$ & 31 & 25.1 \\
\hline MA-080980 & 20.9 & 14.2 & 6.3 & 3.5 & 34 & 252 & 5.3 & 0.34 & 22 & 143 & 116 & $<8$ & 20.9 & 29.3 \\
\hline MA-080977 & 8.3 & 6.9 & 6.2 & 3.1 & 54 & 112 & 7.2 & 0.04 & 56 & $<64$ & 45 & $<10$ & 12.5 & 8.4 \\
\hline MA-080982 & 14.7 & 16.2 & 280 & 9.0 & 185 & 450 & 5.6 & 0.94 & 1160 & 58 & 133 & $<16$ & 123 & 122 \\
\hline MA-080983 & 12.9 & 13.2 & 134 & 11.2 & 149 & 291 & 4.0 & 0.32 & 33 & $<74$ & 66 & 10 & 33 & 58 \\
\hline MA-080984 & 14.0 & 11.0 & 141 & 6.5 & 79 & 230 & 5.3 & 0.26 & 111 & $<67$ & 82 & $<13$ & 180 & 75 \\
\hline MA-080985 & 27.4 & 14.6 & 63 & 4.6 & 53 & $<74$ & 12.3 & 0.19 & 43 & $<66$ & 145 & 7 & 19.0 & 17.7 \\
\hline MA-080978 & 25.3 & 14.1 & 4.0 & 6.5 & 5.5 & 91 & 9.2 & 0.13 & 44 & 43 & 109 & 7 & 13.7 & 9.8 \\
\hline MA-081637 & 11.7 & 10.1 & 74 & 5.9 & 42 & $<132$ & 4.5 & 0.16 & 51 & $<231$ & 58 & 11 & n.d. & n.d. \\
\hline MA-081638 & 21.0 & 19.9 & 105 & 9.1 & 138 & 200 & 13.1 & 0.32 & 262 & $<320$ & 119 & $<17$ & n.d. & n.d. \\
\hline MA-081639 & 23.3 & 7.2 & 13.6 & 1.93 & 4.8 & $<99$ & 3.9 & 0.12 & 15.6 & $<222$ & 23.8 & 6 & n.d. & n.d. \\
\hline MA-080989 & 31 & 16.6 & 94 & 11.3 & 40 & $<106$ & 36 & 0.10 & 112 & 99 & 17 & 51 & 36 & 12.8 \\
\hline
\end{tabular}


Tab. 5. Lead isotope ratios in ore samples from the Mitterberg region as determined by multi collector inductively coupled mass spectrometry. The precision of measurement is less than $\pm 0.01 \%$ for ratios with ${ }^{206} \mathrm{~Pb}$ in the denominator and up to $\pm 0.03 \%$ for ${ }^{206} \mathrm{~Pb} /{ }^{204} \mathrm{~Pb}$.

\begin{tabular}{|l|c|c|c|}
\hline Lab no. & ${ }^{208} \mathrm{~Pb} /{ }^{206} \mathrm{~Pb}$ & ${ }^{207} \mathrm{~Pb} /{ }^{206} \mathrm{~Pb}$ & ${ }^{206} \mathrm{~Pb} /{ }^{204} \mathrm{~Pb}$ \\
\hline MA-080582 & 1.9506 & 0.76286 & 20.697 \\
\hline MA-080583 & 2.0247 & 0.80003 & 19.668 \\
\hline MA-080584 & 2.0406 & 0.80960 & 19.415 \\
\hline MA-080585 & 2.0342 & 0.80424 & 19.558 \\
\hline MA-080586 & 2.0378 & 0.80788 & 19.458 \\
\hline MA-080587 & 2.0172 & 0.79758 & 19.730 \\
\hline MA-080588 & 2.0388 & 0.80836 & 19.447 \\
\hline MA-080589 & 2.0406 & 0.80944 & 19.427 \\
\hline MA-081367 & 1.9894 & 0.78407 & 20.101 \\
\hline MA-081368 & 2.0396 & 0.82366 & 19.031 \\
\hline MA-081369 & 1.9462 & 0.76366 & 20.678 \\
\hline MA-081370 & 1.9968 & 0.79159 & 19.894 \\
\hline MA-081372 & 1.9926 & 0.78955 & 19.944 \\
\hline MA-081373 & 2.0334 & 0.80943 & 19.415 \\
\hline MA-081375 & 2.0468 & 0.83419 & 18.766 \\
\hline MA-081377 & 2.0320 & 0.79670 & 19.733 \\
\hline MA-081378 & 1.9006 & 0.69971 & 22.697 \\
\hline MA-081379 & 2.0249 & 0.79952 & 19.678 \\
\hline MA-081380 & 2.0259 & 0.79932 & 19.678 \\
\hline MA-081381 & 2.0394 & 0.80662 & 19.494 \\
\hline MA-081383 & 2.0267 & 0.80010 & 19.665 \\
\hline MA-081384 & 2.0154 & 0.79152 & 19.890 \\
\hline MA-081385 & 1.9938 & 0.78264 & 20.137 \\
\hline MA-081386 & 1.9429 & 0.76350 & 20.671 \\
\hline MA-081389 & 1.9067 & 0.73051 & 21.683 \\
\hline MA-081390 & 1.9862 & 0.77856 & 20.249 \\
\hline MA-081391 & 2.0082 & 0.79452 & 19.802 \\
\hline MA-081392 & 1.9560 & 0.76591 & 20.612 \\
\hline MA-081394 & 2.0027 & 0.78665 & 20.036 \\
\hline MA-081395 & 1.9447 & 0.75977 & 20.785 \\
\hline MA-081396 & 1.9264 & 0.73940 & 21.403 \\
\hline MA-081399 & 2.0194 & 0.78796 & 20.016 \\
\hline MA-081401 & 2.0564 & 0.81530 & 19.268 \\
\hline MA-081402 & 2.0536 & 0.81252 & 19.345 \\
\hline MA-081403 & 2.0443 & 0.80595 & 19.507 \\
\hline MA-081405 & 2.0672 & 0.82328 & 19.057 \\
\hline MA-081406 & 2.0753 & 0.81997 & 19.152 \\
\hline MA-081408 & 2.0726 & 0.82894 & 18.918 \\
\hline MA-08141418 & 2.0468 & 0.81917 & 19.174 \\
\hline 081423 & 1.9549 & 0.76661 & 20.584 \\
\hline
\end{tabular}

\begin{tabular}{|c|c|c|c|}
\hline Lab no. & ${ }^{208} \mathrm{~Pb} /{ }^{206} \mathrm{~Pb}$ & ${ }^{20}{ }^{07} \mathrm{~Pb} /{ }^{206} \mathrm{~Pb}$ & ${ }^{206} \mathrm{~Pb} /{ }^{204} \mathrm{~Pb}$ \\
\hline MA-081428 & 1.9820 & 0.77842 & 20.248 \\
\hline MA-081624 & 2.0718 & 0.82074 & 19.125 \\
\hline MA-081625 & 2.0729 & 0.82271 & 19.073 \\
\hline MA-081626 & 2.0893 & 0.83261 & 18.859 \\
\hline MA-081627 & 2.0966 & 0.83710 & 18.754 \\
\hline MA-081628 & 2.0503 & 0.81326 & 19.321 \\
\hline MA-081629 & 2.0478 & 0.80931 & 19.428 \\
\hline MA-081630 & 2.0435 & 0.80563 & 19.522 \\
\hline MA-081631 & 2.0357 & 0.79888 & 19.691 \\
\hline MA-081633 & 2.0637 & 0.82175 & 19.097 \\
\hline MA-081634 & 2.0223 & 0.80523 & 19.531 \\
\hline MA-081635 & 2.0031 & 0.7961 & 19.765 \\
\hline MA-100344 & 2.0764 & 0.81741 & 19.208 \\
\hline MA-100345 & 2.0692 & 0.81256 & 19.329 \\
\hline MA-100346 & 2.0657 & 0.81928 & 19.160 \\
\hline MA-100347 & 2.0727 & 0.82506 & 19.010 \\
\hline MA-100348 & 2.0590 & 0.81526 & 19.254 \\
\hline MA-100349 & 2.0978 & 0.83376 & 18.839 \\
\hline MA-100350 & 2.0731 & 0.82934 & 18.926 \\
\hline MA-100351 & 2.0002 & 0.77276 & 20.422 \\
\hline MA-100352 & 2.0401 & 0.79974 & 19.693 \\
\hline MA-100353 & 2.0663 & 0.81755 & 19.233 \\
\hline MA-100354 & 2.0484 & 0.80517 & 19.546 \\
\hline MA-100355 & 2.0926 & 0.84995 & 18.430 \\
\hline MA-100356 & 2.0818 & 0.83608 & 18.768 \\
\hline MA-100357 & 2.0681 & 0.82343 & 19.074 \\
\hline MA-100358 & 2.0857 & 0.83905 & 18.693 \\
\hline MA-100359 & 2.0822 & 0.84040 & 18.658 \\
\hline MA-080975 & 2.0522 & 0.83268 & 18.829 \\
\hline MA-080976 & 2.0964 & 0.82880 & 18.922 \\
\hline MA-080979 & 2.0910 & 0.81932 & 19.202 \\
\hline MA-080981 & 2.0976 & 0.80315 & 19.615 \\
\hline MA-080980 & 2.0880 & 0.81619 & 19.277 \\
\hline MA-080977 & 2.0814 & 0.83662 & 18.750 \\
\hline MA-080982 & 2.0975 & 0.80686 & 19.495 \\
\hline MA-080983 & 2.0978 & 0.80582 & 19.546 \\
\hline MA-080984 & 2.0997 & 0.80650 & 19.540 \\
\hline MA-080985 & 2.0987 & 0.82929 & 18.948 \\
\hline MA-080978 & 2.0904 & 0.83580 & 18.791 \\
\hline MA-080989 & 1.6772 & 0.68406 & 23.248 \\
\hline
\end{tabular}


Tab. 6. Lead isotope ratios in slag samples from different slag heaps as determined by multi collector inductively coupled mass spectrometry. The precision of measurement is less than $\pm 0.01 \%$ for ratios with ${ }^{206} \mathrm{~Pb}$ in the denominator and up to $\pm 0.03 \%$ for ${ }^{206} \mathrm{~Pb} /{ }^{204} \mathrm{~Pb}$.

\begin{tabular}{|l|l|c|c|c|}
\hline Lab no. & Location & ${ }^{208} \mathrm{~Pb} /{ }^{206} \mathrm{~Pb}$ & ${ }^{207} \mathrm{~Pb} /{ }^{206} \mathrm{~Pb}$ & ${ }^{206} \mathrm{~Pb} /{ }^{204} \mathrm{~Pb}$ \\
\hline MA-091529 & SP AA Widersberg-Alp. Schlacke am Bach & 2.0155 & 0.80029 & 19.655 \\
\hline MA-091530 & SP 04 Widersberg-Alp & 1.9839 & 0.78589 & 20.032 \\
\hline MA-091531 & SP 06 Dientner Sattel & 2.0187 & 0.80220 & 19.609 \\
\hline MA-091532 & SP 07 Dientner Sattel & 2.0157 & 0.80228 & 19.602 \\
\hline MA-091533 & SP 09 Dientner Sattel & 2.0144 & 0.80139 & 19.629 \\
\hline MA-091534 & SP 12 Widersberg-Alp & 2.0108 & 0.79691 & 19.749 \\
\hline MA-091536 & SP 13 S-Teil Widersberg-Alp & 2.0018 & 0.79448 & 19.813 \\
\hline MA-091537 & SP 14 Widersberg-Alp & 2.0082 & 0.79958 & 19.671 \\
\hline MA-091538 & SP 14A Widersberg-Alp & 2.0257 & 0.80679 & 19.482 \\
\hline MA-091539 & SP 15-1 Widersberg-Alp. Kopphütte & 2.0013 & 0.79688 & 19.735 \\
\hline MA-091540 & SP 15-2 Widersberg-Alp. Kopphütte & 2.0570 & 0.83214 & 18.822 \\
\hline MA-091541 & SP 16 Kopphütte & 2.0213 & 0.80571 & 19.509 \\
\hline MA-091542 & SP 22 Windrauchegg & 2.0251 & 0.80753 & 19.468 \\
\hline MA-091543 & SP 23 Hochkeil & 2.0252 & 0.80715 & 19.475 \\
\hline MA-091544 & SP 40 Widersberg-Alp & 1.9914 & 0.78976 & 19.936 \\
\hline MA-091545 & SP 47 Hochkeil & 1.9808 & 0.78415 & 20.089 \\
\hline MA-091546 & SP 59-1 Burgschwaig & 2.0496 & 0.82282 & 19.065 \\
\hline MA-091547 & SP 59-2 Burgschwaig & 2.0105 & 0.78117 & 20.179 \\
\hline MA-091548 & SP 64 Winklgang & 2.0533 & 0.81656 & 19.226 \\
\hline MA-091549 & MB 08-03 Hauptgang Nähe Danielstollen & 2.0208 & 0.80518 & 19.527 \\
\hline MA-091550 & MB 08-22/1 Buchberg & 2.0722 & 0.83483 & 18.777 \\
\hline MA-091551 & MB 08-22/2 Buchberg & 2.0933 & 0.84738 & 18.480 \\
\hline
\end{tabular}

